\title{
Van mate van schuld: over ondergrens (en bovengrens) van de culpa in het Nederlandse strafrecht
}

\author{
Wim Vellinga ${ }^{429}$
}

I Een vraag van inhoud en maat

\section{I.I Hoe het begon}

Dit preadvies gaat over schuld in het Nederlandse strafrecht. Nauwkeuriger gezegd: over de inhoud van het bestanddeel schuld zoals dat voorkomt in een aantal delictsomschrijvingen. Ten tijde van de totstandkoming van het Wetboek van Strafrecht in de jaren I88I-I886 zag de wetgever deze schuld of culpa als 'de zuivere tegenstelling van opzet aan de eene, van toeval (casus) aan de andere zijde'. Deze schuld kon zich in velerlei vorm voordoen - 'verzuim, nalatigheid, onvoorzigtigheid, gebrek aan voorzorg enz.' - doch daarin zag de regering geen aanleiding de inhoud van de schuld nader te omschrijven. In de ogen van de regering diende aan de rechter de vrijheid te worden gelaten aan de hand van de omstandigheden van het geval te bepalen of 'bij gebreke van opzet, het feit aan den beklaagdes schuld is te wijten'. ${ }^{430}$

De Tweede Kamer dacht daarover aanvankelijk anders. Haars inziens mocht er geen misverstand over bestaan dat de strafwet culpa levis niet wil treffen 'vooral ook omdat in jure civili reeds ontstentenis van overmagt of toeval voldoende kan zijn om aansprakelijkheid te doen ontstaan'. Daarom stelde zij voor aansluiting te zoeken bij art. 4I8 van de Code Pénal Belge, waarin wordt gesproken van 'défaut de prévoyance ou de précaution' dan wel te bepalen dat 'onder schuld verstaan wordt grove onachtzaamheid of onvoorzichtigheid'. ${ }^{4{ }^{\mathrm{r}}}$

Toenmalig Minister van Justitie Modderman voelde niet voor een nadere beschrijving van het begrip schuld. Hij vatte eerst de kern van de schuld nog eens samen: 'Gebrek aan het noodige nadenken, aan de noodige kennis of aan het noodige beleid, ziedaar het wezen van alle schuld.'

Vervolgens stelde hij de vraag 'Hoeveel nadenken, hoeveel kennis, hoeveel beleid is er nu noodig om van schuld vrij te wezen, met andere woorden hoe groot moet het gebrek aan nadenken, kennis, beleid zijn om als schuld te kunnen worden

429 W.H. Vellinga is advocaat-generaal bij de Hoge Raad der Nederlanden en hoogleraar straf- en strafprocesrecht aan de Rijksuniversiteit te Groningen.

430 Smidt I, p. 77.

43I Smidt I, p. 78. 
toegerekend? Is het voldoende dat men niet zóó nadacht, niet zóóveel wist, niet zóóveel beleid aanwendde als de meest nadenkende, de meest kundige, de meest voorzichtige mensch (culpa levis)? Of wordt vereist dat men minder nadacht, wist, beleidvol was dan de mensch in het algemeen (culpa lata)?' Over het antwoord op deze vraag hoefde volgens de Minister geen misverstand te bestaan: 'Zonder twijfel moet dezen vraag in den laatsten zin worden beantwoord. Alleen die schuld (hetzij bewuste schuld of roekeloosheid, hetzij onbewuste schuld), behoort tot het gebied van 't strafrecht die in foro civili "culpa lata" genoemd wordt. ${ }^{232}$ Vervolgens legde de Minister uit dat van iemand die handelt in de uitoefening van een beroep meer wordt gevergd dan van de mens in het algemeen maar dat niet reeds van culpa lata kan worden gesproken wanneer een beroepsbeoefenaar niet voldoet aan de eisen waaraan alleen de uitmuntendste beroepsbeoefenaar kan voldoen. Wel een Garantenstellung dus, maar niet één die verder gaat dan hetgeen in het algemeen van een beoefenaar van een bepaald beroep kan worden geëist. Vervolgens gaf de Minister aan dat hij bereid was in plaats van 'schuld' van 'grove schuld' te spreken, doch nodig achtte hij dit niet: de uitlegger behoort te weten dat de strafwetgever het oog heeft op de burger in het algemeen, 'niet op den diligentissimus paterfamilias'. Voor een definitie van 'schuld' in het Wetboek van Strafrecht voelde de Minister niets. Een dergelijke bepaling zou een doctrinair karakter krijgen en daarvoor was in het Wetboek geen plaats. Een omschrijving als in art. 4I8 van de Code Pénal Belge 'defaut de prévoyance ou de précaution' leerde de rechter niet 'wanneer men een dergelijk défaut moet aannemen'. 433

Voor culpa was dus vereist grove schuld. De uitwerking van deze opvatting in de rechtspraak liet niet lang op zich wachten. In HR I4 november I887, W 5509 was aan de orde de vervolging van een machinist van de tram Heerenveen-Joure ${ }^{434}$ wegens schuld aan zodanig lichamelijk letsel van een voerman van een omnibus dat deze verhinderd was in de uitoefening van zijn beroepsbezigheden (art. 308 (oud) Sr). De voerman had de omnibus door sneeuw en ijs niet tijdig uit de nabijheid van het door de tram te volgen spoor kunnen verwijderen - de omnibus stond op één meter van het door de tram te volgen spoor - en daarom had hij naar de machinist gewenkt en geschreeuwd, maar deze had daarop geen acht geslagen en was doorgestoomd waardoor de paarden schichtig werden, de tram met de paarden en de omnibus in aanraking kwam en de voerman bekneld raakte tussen de tram en de omnibus met bovenbeschreven gevolg. Het hof achtte deze feiten toereikend om tot aanmerkelijke schuld van de machinist aan het lichamelijk letsel van de voerman te komen. ${ }^{435}$ De machinist, aldus het hof, had niet de alleruiterste voorzichtigheid betracht, temeer niet nu het ging om een extra tram. De Hoge Raad zag dit anders. Zijns inziens had

432 Smidt I, p. 78.

433 Smidt I, p. 79.

434 Deze tramlijn werd geopend op 26 maart I882 (J.J. Tiedema en J.J. Buikstra, Friesland rond per tram, Deventer-Antwerpen: Kluwer Technische Boeken B.V., I982, p. I8). Zie voor verslagen van de behandeling van de zaak bij Hof en Hoge Raad de Leeuwarder Courant van 29 juni, 2 juli en 6 oktober 1887 , te vinden op www.archiefleeuwardercourant.nl.

435 De tenlastelegging sprak niet van aanmerkelijke onoplettendheid of onvoorzichtigheid maar bevatte louter het hiervoor weergegeven relaas. 
het hof te hoge eisen aan de machinist gesteld. Daartoe wees de Hoge Raad erop dat culpa, faute, Fahrlässigkeit niet de geringste onachtzaamheid of het niet betrachten der alleruiterste voorzichtigheid omvat. Schuld moest, zoals bleek uit de parlementaire behandeling van het Wetboek van Strafrecht, worden verstaan als een min of meer grove of aanmerkelijke onvoorzichtigheid, onachtzaamheid of nalatigheid.

\section{I.2 Naar de vraagstelling}

Het valt op dat de wetgever de culpa vooral zag in het gebrek aan voorzorg. Over enkele onoplettendheid, heden ten dage in het verkeer een belangrijke oorzaak van dood of letsel, werd niet gesproken. Verder werd met name gedacht aan (uit de aard der zaak) ter zake kundige beroepsbeoefenaren die fouten makten. Over schuld aan ernstige gevolgen van door burgers bij deelname aan het maatschappelijk verkeer gemaakte fouten, zoals bij deelname aan het wegverkeer, het werken in fabrieken en werkplaatsen en de sportbeoefening, ${ }^{436}$ werd geen aandacht gegeven. Evenmin werd de vraag onder ogen gezien of en in hoeverre het met het oog op het doelmatig functioneren van de samenleving geoorloofd was enig risico te nemen. Ook liet de wetgever onbesproken hoe dient te worden gewogen dat de inrichting van de omgeving waarin iemand werkt of anderszins aan het maatschappelijk verkeer deelneemt het maken van fouten in de hand kan werken of juist kan tegengaan. Sprekend is in dit verband dat het spoorwegverkeer zo kan worden ingericht dat een machinist niet door rood sein kan rijden en daarmee buitengewoon ernstige culpoze delicten kunnen worden voorkomen.

Dat de wetgever deze vragen niet onder ogen heeft gezien behoeft geen verbazing te wekken. De industriële revolutie met de daaraan verbonden gevaren van ontploffende stoomketels en onbeschermd draaiende delen ${ }^{437}$ kwam in Nederland pas in de tweede helft van de negentiende eeuw langzaam op gang. ${ }^{438}$ Kennis hoe met de nieuwe machines om te gaan moest door ervaring worden opgedaan. Welke eisen aan de bediening daarvan konden worden gesteld en wat van de bedienaars aan zorgvuldigheid en oplettendheid kon worden gevergd was dus niet aanstonds duidelijk. Veel oog voor het lot van zij die verkeerden op de werkvloer en die juist daardoor degenen waren die gevaar liepen, bestond er nog niet. ${ }^{439}$ Misschien heeft hier ook een rol gespeeld dat in kringen van juristen mogelijk geen affiniteit bestond met techniek. Van der Woud wijst erop dat Nederlandse techniek - anders dan de Duitse en de Franse - geen (in de militaire oorsprong gelegen) aristocratische of culturele

436 Zie bijv. HR 7 februari 20I2, LJN BU2878, NJ 20I2, II9 (klimwandongeval).

437 Die Industrielle Revolution, Wie Dampf, Stahl und Strom die Welt änderden, Geo epoche Das Magazin für Geschichte, 2008, nr. 30, p. 78, II2.

438 Auke van der Woud, Een nieuwe wereld. Het ontstaan van het moderne Nederland, Amsterdam: Uitgeverij Bert Bakker 2007, p. II5 e.v.

439 Auke van der Woud, Koninkrijk van sloppen. Achterbuurten en vuil in de negentiende eeuw, Amsterdam: Uitgeverij Bert Bakker 20I0. De Veiligheidswet, die bepalingen bevatte over de veiligheid in fabrieken, dateert van 1895 . Deze kwam tot stand naar aanleiding van een in de jaren I886 en I887 uitgevoerde parlementaire enquête naar o.m. de toestand in fabrieken en werkplaatsen met het oog op de veiligheid, de gezondheid en het welzijn der werklieden (http://www. parlement.com/929I0oo/modulesf/g8pjsgep). 
context had, die ervoor zorgde dat openbare werken met gecultiveerde smaak werden ontworpen, dat waterbouwkundige werken een opzettelijk culturele luister kregen..$^{4{ }^{\circ}}$ Ten tijde van de totstandkoming van het Wetboek waren er geen auto's, fietsen nauwelijks. De huidige belangenbehartiger van - onder meer - automobilisten, de ANWB, werd in 1883 opgericht als Algemene Nederlandsche Wielrijdersbond. Dat burgers in het leven van alledag de beschikking zouden krijgen over instrumenten waarmee zij zich snel en onafhankelijk van anderen konden verplaatsen maar in geval van onzorgvuldigheid of onoplettendheid door de daaraan soms verbonden ernstige gevolgen ook binnen het bereik van de strafwet konden vallen, was niet voorzien.

Een en ander brengt ons bij de vraag die in dit preadvies een centrale plaats zal innemen: waar ligt thans - naar huidige maatschappelijke omstandigheden en verhoudingen - de ondergrens van de schuld zoals deze voor culpoze misdrijven wordt dan wel behoort te worden geëist? En, daarmee samenhangend: kan ook iets worden gezegd over de bovengrens van de schuld anders dan dat van culpa geen sprake meer is wanneer de dader opzet heeft, minstgenomen in de vorm van voorwaardelijk opzet?

Reeds hier kan worden opgemerkt dat de wetgever aan de beantwoording van deze vragen niet wezenlijk heeft bijgedragen. Er zijn op tal van gebieden veiligheidsvoorschriften uitgevaardigd maar welke de gevolgen daarvan zijn voor de inhoud van de culpa heeft de wetgever in het midden gelaten.

\section{Culpa in de wet}

De grondvorm van de delictsomschrijving van het culpoze delict vinden we in art. $307 \mathrm{Sr}$ : 'Hij aan wiens schuld de dood van een ander te wijten is, wordt gestraft met .... Deze delictsomschrijving wordt er in de eerste plaats door gekenmerkt dat de inhoud van de schuld niet nader wordt omschreven en dus in het licht van de parlementaire geschiedenis moet worden verstaan als aanmerkelijke schuld. Het tweede kenmerk bestaat hierin dat de schuld is betrokken op een concreet gevolg, zoals hier de dood van een ander. Dit tweede kenmerk wordt ook wel geduid als het schuldverband. ${ }^{4{ }^{\mathrm{I}}}$ Of, om het anders te zeggen, schuld zonder gevolg is niet goed denkbaar. We spreken immers van schuld aan iets. Ook al toont iemand - in de woorden van Minister Modderman - gebrek aan voorzorg, aan het nodige beleid, van schuld kan pas worden gesproken als dat gebrek aan voorzorg, aan het nodige beleid tot een in de wet aangewezen gevolg heeft geleid, zoals in art. $307 \mathrm{Sr}$ de dood van een ander. Het gaat om gebrek aan voorzorg, aan het nodige beleid met het oog

440 Auke van der Woud, Een nieuwe wereld. Het ontstaan van het Moderne Nederland, Amsterdam: Uitgeverij Bert Bakker 2007, p. I27.

44I Gevaar en schuld op de weg, Alphen aan den Rijn: H.D. Tjeenk Willink I979, p. IIo en HR I februari 2005, LJN AP4584, NJ 2006, 42I, rov. 8.8.I. Zie ook Hans-Heinrich Jescheck, Lehrbuch des Strafrechts, allgemeiner Teil, Berlin: Duncker \& Humblot I996, vijfde druk, p. 582, 583. 
op het voorkomen van het in de wet genoemde gevolg, in casu de dood. Zo drukt dat gevolg een stempel op de vereiste schuld.

Heeft de schuld in art. $307 \mathrm{Sr}$ betrekking op het veroorzaken van dood, in art. 308 Sr betreft de schuld het veroorzaken van - kort gezegd - zwaar lichamelijk letsel. In gemeengevaarlijke delicten grijpt de schuld aan op het veroorzaken van brand, ontploffing of overstroming (art. $158 \mathrm{Sr}$ ), op het vernielen, beschadigen of onbruikbaar maken van een elektriciteitswerk (art. I6rbis Sr), op het in gevaar brengen van het verkeer op de spoorweg (art. I65 Sr) en dergelijke. Deze gemeengevaarlijke delicten verschillen in zoverre van de grondvorm van het culpoze delict dat de gevolgen van deze brand, overstroming etc. zoals de dood van een ander, strafverzwarende omstandigheden vormen, ook al is de culpa daarop niet betrokken.

Er zijn ook delictsomschrijvingen waarin de schuld betrekking heeft op een bepaalde omstandigheid waaronder de in de delictsomschrijving beschreven gedraging plaatsvindt. Dan wordt de culpa niet uitgedrukt in termen van 'aan zijn schuld te wijten', maar bezigt de wetgever termen als 'ernstige reden heeft om te vermoeden (dat in het geschrift of de afbeelding een aanbod tot het verschaffen van inlichtingen c.a. om een strafbaar feit te plegen voorkomt)' (art. 134 Sr), 'redelijkerwijs had moeten vermoeden (dat een goed van misdrijf afkomstig is)' (art. 4I7 bis Sr) en dergelijke.

Vermelding verdient nog de - unieke - wijze waarop in art. 6 WVW r994 dood en zwaar lichamelijk letsel door schuld in het verkeer is omschreven. Art. 6 vormt een herformulering van art. $36 \mathrm{WVW}$ (oud), een bepaling die op haar beurt weer was gebaseerd op art. 307 en 308 Sr. Dat was geschied door aan de tekst van de art. 307 en $308 \mathrm{Sr}$ bestanddelen toe te voegen, inhoudende - kort gezegd - dat de dood of het letsel was veroorzaakt door een botsing, aan- of overrijding met een door hem bestuurd motorrijtuig of een handeling ter voorkoming daarvan. Zo werd bereikt dat art. $36 \mathrm{WVW}$ (oud) ${ }^{442}$ alleen betrekking had op - kort gezegd - dood en zwaar lichamelijk letsel in het verkeer. Daaraan was een zwaardere gevangenisstraf verbonden en bovendien de bijkomende straf van ontzegging van de bevoegdheid motorrijtuigen te besturen. In art. $6 \mathrm{WVW}^{443}$ is deze opbouw verlaten. Deze bepaling spreekt van het verbod zich zodanig te gedragen dat een aan zijn schuld te wijten verkeersongeval plaatsvindt waardoor een ander wordt gedood etc. Overigens beoogde de wetgever met deze verandering van opbouw van de strafbepaling niet enige wijziging ten opzichte van art. $36 \mathrm{WVW}$ (oud). ${ }^{444}$ In het navolgende zal ik er

442 Deze bepaling luidde voor zover hier van belang: 'Degene, aan wiens schuld, bij gelegenheid van eene botsing, aan- of overrijding met een door hem bestuurd motorrijtuig, (...) de dood van een ander te wijten is, wordt, indien de dood door de botsing, aan- of overrijding (...) is veroorzaakt, gestraft met ...:'.

443 Het is een ieder die aan het verkeer deelneemt verboden zich zodanig te gedragen dat een aan zijn schuld te wijten verkeersongeval plaatsvindt waardoor een ander wordt gedood of waardoor een ander zwaar lichamelijk letsel wordt toegebracht of zodanig lichamelijk letsel dat daaruit tijdelijke ziekte of verhindering in de uitoefening van de normale bezigheden ontstaat.

444 Kamerstukken II I990-I99I, 22 030, nr. 3, p. 68. Anders H.G.M. Krabbe in: De Wegenverkeerswet I994, onder redactie van A.E. Harteveld en H.G.M. Krabbe, Arnhem: Gouda Quint 1999, p. II8 e.v. 
dan ook van uitgaan dat er voor wat betreft de inhoud van de culpa geen verschil bestaat tussen art. $36 \mathrm{WVW}$ (oud) en het huidige art. $6 \mathrm{WVW}$ I994.

\section{Culpa in ontwikkeling}

\section{I De rechter past toe, de wetenschap exploreert}

Het arrest van de Hoge Raad over het tramongeval laat zien dat de rechtspraak met de beschrijving van de inhoud van de culpa, zoals deze tijdens de parlementaire behandeling was gegeven, uit de voeten kon. Er volgen tientallen jaren waarin het niet tot opvallende uitspraken komt. Met de komst van de auto en de opkomst van het wegverkeer zien we verkeersongevallen op de weg in de rechtspraak een steeds dominantere plaats innemen, reden voor de wetgever om aan art. 307 e.v. Sr de bijkomende straf van ontzegging der rijbevoegdheid te verbinden. ${ }^{445}$ Buiten het verband van het culpoze delict werd echter een uitspraak gedaan die bij de ontwikkeling van de inhoud van de culpa een belangrijke rol zou gaan spelen..$^{446}$ Op I4 februari igr6 oordeelde de Hoge Raad in het zogenaamde Water en melk-arrest ${ }^{447}$ dat een Amsterdamse knecht, die in opdracht van zijn baas doch in strijd met de algemene politieverordening met water aangelengde melk als melk had verkocht, ter zake bij gebrek aan schuld straffeloos kon zijn, ook al was de schuld niet als bestanddeel in de verbodsbepaling opgenomen: 'dat toch niets, bepaaldelijk niet de geschiedenis van het Wetboek van Strafrecht, er toe dwingt om aan te nemen dat bij het niet-vermelden van schuld als element in de omschrijving van een strafbaar feit, in het bijzonder van een overtreding, onze wetgever het stelsel huldigt, dat bij gebleken afwezigheid van alle schuld niettemin strafbaarheid zou moeten worden aangenomen, tenzij er een grond voor uitsluiting daarvan in de wet mocht zijn aangewezen; (...).'

Anders dan in de rechtspraak vormde in de wetenschap de inhoud van de culpa voorwerp van indringend onderzoek. Dit onderzoek was ingegeven door een met name door de Duitse literatuur geïnspireerde zoektocht naar de opbouw van het strafbaar feit. Daarbij was uitgangspunt dat het strafbaar feit zo diende te worden opgebouwd dat daaruit de oplegging van straf kon worden verklaard. Dit strafbaar feit werd opgebouwd gedacht uit twee elementen, wederrechtelijkheid als de objectieve zijde van het strafbaar feit, schuld als de subjectieve zijde. Had iemand zich in strijd met de (straf)wet gedragen en had hij daar schuld aan, dan was het - zo was de gedachte - gerechtvaardigd straf op te leggen, anders niet. Deze schuld bestond uit opzet of onachtzaamheid. Vraag was welke inhoud dit begrip onachtzaamheid had, en voorts of met deze onachtzaamheid de subjectieve zijde van het culpoze delict volledig was beschreven.

445 Wet van I november I924, Stb. 492.

446 Ik kom daar onder o op terug.

447 HR i4 februari igr6, NJ I9ı6, p. 68I, W9958 (Water en melk-arrest). 


\subsection{Ontdekking van de bouwstenen van de schuld}

Met schuld als de subjectieve zijde van het strafbaar feit ${ }^{448}$ werd de geestesgesteldheid aangeduid waarmee een dader een strafbaar feit pleegde. Beide vormen van schuld, opzet en onachtzaamheid, bestonden in een bepaalde bewustzijnsinhoud van de dader. Bij opzet stond het willen en/of weten voorop, bij onachtzaamheid het ontbreken daarvan.

Met de op een bepaalde bewustzijnsinhoud gebaseerde formulering van het voorwaardelijk opzet werd een duidelijke grens aangegeven tussen opzet en onachtzaamheid en daarmee ook de bovengrens van de onachtzaamheid, de bewuste schuld. Toch rees de vraag of met opzet en onachtzaamheid als een bepaalde bewustzijnsinhoud de schuld wel toereikend was beschreven. Zo sprong in het oog ${ }^{449}$ dat onachtzaamheid even goed kon bestaan ten aanzien van een geoorloofde, niet strafbare handeling als ten aanzien van een door de wet verboden handeling. Het inzicht dat juist normatieve begrippen kenmerkend zijn voor de juridische wetenschap bracht uitkomst. Onachtzaam zijn was voor de schuld niet genoeg, het ging om ongeoorloofde onachtzaamheid, dus om onachtzaamheid waar men 'achtzaam' - oplettend, zorgvuldig, voorzichtig - had behoren te zijn. Anders gezegd: gaat het om schuld ten aanzien van een gevolg van handelen of nalaten, dan bestaat de onachtzaamheid in niet voorzien waar men dat gevolg ${ }^{45}$ behoorde te voorzien, betreft de schuld een omstandigheid waaronder een gedraging wordt verricht, dan is men onachtzaam wanneer men van die omstandigheid niet op de hoogte was doch dat wel had moeten zijn.

Naast wederrechtelijkheid en schuld bestonden gronden van ontoerekenbaarheid; ontoerekeningsvatbaarheid (art. $37 \mathrm{Sr}$ ) als inwendige grond van ontoerekenbaarheid en overmacht, noodweer, noodweerexces etc. (art. 40-43 $\mathrm{Sr}$ ) als uitwendige gronden van ontoerekenbaarheid. Over de verhouding tussen beide elementen van het strafbaar feit en de gronden van ontoerekenbaarheid werd verschillend gedacht. Aanvankelijk werden de gronden van ontoerekenbaarheid wel los van wederrechtelijkheid en schuld in aanmerking genomen, maar deze werden ook wel gezien als gronden die de wederrechtelijkheid en/of de schuld wegnamen, de uitwendige gronden van ontoerekenbaarheid de wederrechtelijkheid, de inwendige gronden van ontoerekenbaarheid de schuld.

Het onderscheiden van uitwendige gronden van ontoerekenbaarheid in gronden die de wederrechtelijkheid wegnamen en gronden die de schuld wegnamen liet zien dat de schuld met opzet en onachtzaamheid niet toereikend was beschreven. Had iemand een ander opzettelijk van het leven beroofd doch ging hij vrijuit omdat hij had gehandeld in noodweerexces dan had hij wel schuld - hij had opzet en was niet

448 De paragrafen 3.2 en 3.3 berusten op Hoofdstuk 4 van Schuld in spiegelbeeld, diss. Groningen I982.

449 Schuld in spiegelbeeld, p. 39.

450 Volgens Van Dijk (A.A. van Dijk, Strafrechtelijke aansprakelijkheid heroverwogen. Over opzet, schuld, schulduitsluitingsgronden en straf, diss. Groningen 2008), p. 46 e.v.: de kans op dat gevolg. Als in de tekst: Robroek (R. Robroek, Onbewuste culpa. Een analyse van de ondergrens van de strafrechtelijke aansprakelijkheid, Tilburg: Celsus juridische uitgeverij 20Io), p. I3. 
ontoerekeningsvatbaar - maar werd niet gestraft. Die straffeloosheid moest worden toegeschreven aan het feit dat hij in de omstandigheden van het geval niet anders had kunnen handelen. Met dat inzicht was een nieuw element van de schuld geboren: het redelijkerwijs anders kunnen handelen, ook wel samengevat als verwijtbaarheid of - sprekender - vermijdbaarheid. Onder dat nieuwe element liet zich ook de ontoerekeningsvatbaarheid als inwendige grond van ontoerekenbaarheid rangschikken. In geval van ontoerekeningsvatbaarheid kon de verdachte immers redelijkerwijs niet anders handelen, zij het niet op grond van buiten zijn persoon liggende omstandigheden maar vanwege in zijn persoon gelegen gebrekkige ontwikkeling of ziekelijke storing der geestvermogens.

Het voorgaande leidde tot de conclusie dat de schuld voor wat betreft doleuze delicten bestaat in twee componenten, opzet en verwijtbaarheid, voor culpoze delicten in drie componenten, onachtzaamheid, de ongeoorloofdheid daarvan en verwijtbaarheid (vermijdbaarheid) van die ongeoorloofde onachtzaamheid.

\subsection{De verhouding tussen de bestanddelen van het delict en wederrechtelijkheid en schuld als elementen van het strafbaar feit}

$\mathrm{Nu}$ eenmaal duidelijk was hoe het strafbaar feit als grondslag voor de oplegging van straf was opgebouwd rees de vraag of en in hoeverre dit model van het strafbaar feit uitdrukking had gevonden in delictsomschrijvingen. Voor doleuze delicten was dit helder. Het opzet had uitdrukking gevonden in de bestanddelen van het delict, het redelijkerwijs anders kunnen handelen - de afwezigheid van schulduitsluitingsgronden - niet. Beide begrippen, opzet en verwijtbaarheid, konden los van elkaar worden gedacht. Had iemand een ander opzettelijk zwaar lichamelijk letsel toegebracht doch daarbij gehandeld in noodweerexces, dan liet het oordeel dat hij, handelende in noodweerexces, redelijkerwijs niet anders had kunnen handelen het opzet onverlet. Voor culpoze delicten lag dit minder eenvoudig. Dit kwam omdat zowel de onachtzaamheid als de verwijtbaarheid een normatieve inslag hadden. Zoals we hebben gezien was met pure onoplettendheid de schuld nog niet gegeven maar ging het om onachtzaamheid waar 'achtzaamheid' werd verlangd. Bij verwijtbaarheid ging het niet louter om de feitelijke vraag of iemand anders had kunnen handelen maar ook om de vraag of hij dat redelijkerwijs anders kon. De vraag rees dus of van iemand kon worden gezegd dat hij zorgvuldiger had moeten zijn terwijl hij verkeerde in een situatie waarin hij redelijkerwijs niet anders kon handelen, bijvoorbeeld omdat hij weliswaar verkeersregels had genegeerd maar dat wel had gedaan omdat hij daartoe werd geprest door een ontsnapte gevangene die onverhoeds bij hem in de auto was gestapt en hem met een vuurwapen dwong zo snel mogelijk weg te rijden dan wel door de op hem uitgeoefende druk niet had gezien wat hij had moeten (voor)zien. ${ }^{45}$ Een ontkennende beantwoording van deze vraag

45I A. Koch, Die Entkriminalisierung im Bereich der fahrlässigen Körperverletzung und Tötung, Berlin: Duncker \& Humblot I998, p. I40 rekent hiertoe 'Notsituationen' en 'anormalen Beschaffenheit der Umstände'. 
ligt voor de hand. Bij culpoze delicten kunnen onachtzaamheid en verwijtbaarheid dus wel worden onderscheiden, maar niet gescheiden. ${ }^{452}$

Voor de wederrechtelijkheid, tot uitdrukking komend in de afwezigheid van rechtvaardigingsgronden, is de band met de onachtzaamheid nog sterker. Wie een beroep op een rechtvaardigingsgrond toekomt, is uiteindelijk niet tekortgeschoten in het behoren te (voor)zien. Met de culpa is dus de afwezigheid van rechtvaardigingsgronden gegeven, een rechtvaardigingsgrond staat aan het aannemen van culpa in de weg.

\subsection{De inhoud van de culpa als bestanddeel van het delict}

De omstandigheid dat onachtzaamheid en verwijtbaarheid wel kunnen worden onderscheiden doch niet gescheiden heeft gevolgen voor de inhoud van de schuld als bestanddeel van delictsomschrijvingen, de culpa. Anders dan bij doleuze delicten ligt de verwijtbaarheid in het subjectieve bestanddeel van het culpoze delict, de culpa, besloten.

Ongeoorloofde onachtzaamheid wordt in de theorie ook wel samengevat met - zoals ik hierna zal doen - de term 'onvoorzichtigheid'. De culpa als bestanddeel van het culpoze delict bestaat dan uit verwijtbare onvoorzichtigheid.

\subsection{Het ontbreken van de beschrijving van een verboden gedraging in het culpoze gevolgsdelict}

Zoals hiervoor onder 2 aan de orde is geweest zijn er culpoze delicten waarin de culpa betrekking heeft op het gevolg en culpoze delicten waarin de culpa een omstandigheid betreft waaronder de in de delictsomschrijving beschreven gedraging plaatsvindt. Laatstgenoemde bepalingen kennen een beschrijving van de verboden gedraging. Bij culpoze gevolgsdelicten is dat niet steeds het geval. Zo stelt art. 307 Sr straf op het aan iemands schuld te wijten zijn dat een ander om het leven is gekomen maar omschrijft niet het verboden handelen of nalaten dat oorzaak moet zijn van het om het leven komen van die ander. Dat verboden handelen of nalaten moet in het begrip 'aan zijn schuld te wijten zijn' besloten worden geacht. Pas wanneer iemands verwijtbare onvoorzichtigheid tot uiting is gekomen in ongeoorloofd handelen of nalaten kan, als dat ongeoorloofde handelen of nalaten tot het in de wet benoemde gevolgd heeft geleid, worden gezegd dat dat gevolg aan verdachtes schuld te wijten is. Anders gezegd, bij culpoze gevolgsdelicten, waarbij de verboden gedraging niet is beschreven, ligt in de strafbepaling de eis besloten dat de verwijtbare onvoorzichtigheid tot uitdrukking is gekomen in een onvoorzichtige gedraging, in handelen of nalaten in strijd met een op een verdachte rustende zorgplicht. Die zorgplicht kan

452 Zo voor het Belgische recht ook Chr. Van den Wyngaert, Strafrecht en strafprocesrecht in hoofdlijnen, Antwerpen/Apeldoorn: Maklu 20II, p. 337: 'De negatieve voorwaarde van de onoverwinnelijkheid [van de dwaling; WHV] valt (...) doorgaans samen met de onachtzaamheid in die zin dat de onachtzaamheid, nl. het gebrek aan voorzorg of voorzichtigheid, vaak zal overeenkomen met de overwinnelijke, foutieve vergissing.' 
worden ontleend aan bestaande regels, zoals veiligheidsvoorschriften, maar kan zijn grondslag ook vinden in de concrete omstandigheden van het geval. ${ }^{453}$

In de hier gesignaleerde leemte in de delictsomschrijving van culpoze gevolgsdelicten lijkt de wetgever te hebben willen voorzien in het hiervoor (onder 2, slot) reeds besproken art. 6 WVW I994 voor zover daarin wordt gesproken van een verbod om zich zodanig te 'gedragen dat een aan zijn schuld te wijten verkeersongeval plaatsvindt'. Het hoeft geen betoog dat met een 'zich zodanig gedragen dat' slechts tot uitdrukking is gebracht dat een gedraging als oorzaak aan het verkeersongeval ten grondslag moet liggen. Dat is geen nieuw inzicht. Bovendien wordt van de aard van de gedraging niet meer gezegd dan dat deze wordt gerelateerd aan de schuld en die relatie dus de aard van de gedraging bepaalt: onvoorzichtig gedrag. Ook dat was al bekend.

\subsection{Van gebrek aan voorzienbaarheid naar handelen in strijd met een zorgplicht en uiteindelijk naar gebrek aan zien}

Van onachtzaamheid pleegt te worden gesproken wanneer de dader een gedraging heeft verricht waarvan hij kon en behoorde te voorzien dat het in de strafwet genoemde gevolg zou kunnen intreden ${ }^{454}$ en hij die deswege achterwege moest laten. Vele van deze gedragingen zijn in de loop der tijd in veiligheidsvoorschriften als verbod beschreven of hebben geleid tot bepalingen die voorschrijven hoe men zich behoort te gedragen, uitgevaardigd om het intreden van in de strafwet genoemde gevolgen te voorkomen. Zo bepaalt het Reglement verkeersregels en verkeerstekens I990 dat bestuurders verplicht zijn zoveel mogelijk rechts te houden (art.3 lid I) en verbiedt dit een voertuig vlak voor of op een voetgangersoversteekplaats in te halen (art. I2). Door deze voorschriften, die juist zijn uitgevaardigd om brokken te voorkomen, raakt de voorzienbaarheid in het concrete geval op de achtergrond. Gelet op de aard van de voorschriften kan en moet immers een ieder voorzien dat het negeren van een dergelijk voorschrift tot ernstige, in de strafwet genoemde gevolgen kan leiden. Dat leidt er toe dat de schuld niet wordt beschreven in termen van voorzienbaarheid maar in termen van schenden van een op de verdachte rustende zorgplicht, te weten van de plicht zich aan de veiligheidsvoorschriften te houden.

Het hoeft geen betoog dat deze ontwikkeling heeft geleid tot een zekere objectivering van de schuld. Sommige auteurs gaan nog verder en zien handelen in strijd met de op de verdachte rustende zorgplicht als kern van de culpa. Dan is met uiterlijk onvoorzichtig gedrag, te weten handelen in strijd met de op de verdachte rustende zorgplicht, de culpa gegeven. Voordeel daarvan was dat een beroep op een strafuitsluitingsgrond, anders dan bij de hiervoor beschreven culpa als verwijtbare onvoorzichtigheid, geen bestrijding van de tenlastegelegde schuld oplevert en de verwerping daarvan dus volgens art. 358 lid 3 jo. 359 lid 2, eerste volzin, Sv in het vonnis gemotiveerd moest worden. Bij een verweer dat neerkomt op bestrijding van

453 Een mooi voorbeeld biedt HR 3 I oktober 2006, LJN AX9I78, NJ 2007, 79, m.nt. N. Keijzer (leestafelzooien).

454 Van Dijk, a.w. p. 54 e.v., spreekt van voorzienbaarheid van de kans op een bepaald gevolg. 
de tenlastegelegde culpa was dat immers niet het geval. ${ }^{455}$ Ook het gedachtegoed van de finale Handlungslehre heeft bij de keuze van onvoorzichtig gedrag als synoniem aan culpa vermoedelijk een rol gespeeld. In deze opvatting wordt er echter aan voorbijgegaan dat niet steeds vanzelfsprekend is dat de verdachte diende te beseffen dat op hem in concreto een bepaalde zorglicht rustte. Wie niet heeft gezien dat in strijd met een bepaald veiligheidsvoorschrift de automatische afslag van een machine is uitgeschakeld en de machine toch in gebruik stelt, heeft geen culpa aan het gevolg wanneer hij niet heeft kunnen en behoren te zien dat de automatische afslag was uitgeschakeld. En een bestuurder heeft geen culpa aan het gevolg wanneer hij niet heeft kunnen en behoren te zien dat het verkeerslicht rood licht uitstraalde. Zo treedt voor de vraag van het kunnen en behoren te voorzien die van het kunnen en moeten zien in de plaats. De nadruk die op gereglementeerde terreinen is komen te liggen op het naleven van zorgplichten betekent dus niet dat daarmee aan de culpa het subjectieve karakter is komen te ontvallen. Het blijft aankomen op persoonlijk tekortschieten, voor wat betreft culpoze gevolgsdelicten tot uiting komend in de eis van onvoorzichtig gedrag.

\subsection{Wisselwerking tussen rechtspraak en theorie; het Verpleegster-arrest}

Op 8 september I96o overhandigde een verpleegster, werkzaam in het ziekenhuis te A. ter assistentie van de chirurg bij een operatie, aan deze door tussenkomst van een andere verpleegster een flesje injectievloeistof met een andere inhoud dan waar hij om had gevraagd. Zij had niet gezien dat op het flesje adrenalini hydrochloridum stond in plaats van het gevraagde provocaïne. De patiënte werd ingespoten met het verkeerde middel en kwam door een adrenalinevergiftiging te overlijden. Eerstgenoemde verpleegster werd vervolgd voor dood door schuld. Zij stelde dat zij wel op het flesje had gekeken maar dat de betekenis van het opschrift van het flesje door niet aan haar te wijten omstandigheden - overwerktheid, werken in een minder vertrouwde omgeving, het ontbreken in de operatiekamer van de normale gebruikelijke orde - niet tot haar was doorgedrongen, en zij zich dus niet aan de haar verweten grove onoplettendheid schuldig had gemaakt. Rechtbank en hof veroordeelden haar omdat 'van een opgeleide operatiezuster als de verdachte, gezien het aan haar uiteraard bekende enorme risico dat is verbonden aan het toedienen van verkeerde middelen, ten allen tijde gevergd kan en moet worden dat zij de betekenis en het opschrift van een flesje of ampul op zich laat inwerken voordat zij de inhoud daarvan aan de chirurg of de instrumenterende zuster voorhoudt tot het vullen van de injectiespuit waarmee een patiënt zal worden ingespoten en dat het niet voldoen aan deze elementaire eis haar in het algemeen als grove schuld moet worden aangerekend.' In cassatie kwam onder meer de vraag aan de orde of rechtbank en hof hadden moeten ingaan op het verweer dat de verdachte, zoals een deskundige had geoordeeld, op het moment dat zij het flesje pakte en het opschrift las in psychische overmacht

455 Thans voorziet art. 359 lid 2, tweede volzin, Sv in de verplichting tot motivering van afwijking van een uitdrukkelijk onderbouwd standpunt (zoals een beroep op een schulduitsluitingsgrond bij een culpoos delict kan zijn). 
verkeerde en op dat moment niet toerekeningsvatbaar was. Naar het oordeel van de Hoge $\mathrm{Raad}^{456}$ was dit niet het geval omdat het verweer bestond in een ontkenning van de bewezenverklaarde mindere of meerdere mate van grove onoplettendheid.

Dit oordeel viel op omdat art. 358 lid 3 jo. 359 lid 2, eerste volzin, Sv voorschrijft dat een beroep op een strafuitsluitingsgrond - hier psychische overmacht en ontoerekeningsvatbaarheid - uitdrukkelijk en gemotiveerd moet worden verworpen. Daar stond tegenover dat het oordeel van de Hoge Raad heel wel verenigbaar was met de in de theorie ontwikkelde inhoud van de culpa. Van de culpa maakte immers deel uit de verwijtbaarheid, dus het ontbreken van schulduitsluitingsgronden als psychische overmacht en ontoerekeningsvatbaarheid.

Het door de Hoge Raad aan de inhoud van de culpa verbonden gevolg dat beroepen op schulduitsluitingsgronden en - naar viel aan te nemen (zie 3.3 slot) - ook beroepen op rechtvaardigingsgronden niet gemotiveerd behoefden te worden weerlegd omdat deze een bestrijding vormden van de tenlastegelegde culpa werd niet door iedereen aanvaardbaar geacht. Een verdachte diende te kunnen nagaan waarom zijn beroep op een strafuitsluitingsgrond niet was gehonoreerd. Teneinde hierin te voorzien verdedigde Van Eck het standpunt dat aan het bewijs van de culpa zo lage eisen werden gesteld dat dit tot gevolg diende te hebben dat beroepen op schulduitsluitingsgronden bij culpoze delicten gemotiveerd werden weerlegd. Anderen sleutelden niet aan het strafprocesrecht ${ }^{457}$ maar aan de inhoud van de culpa. ${ }^{45} \mathrm{Culpa}$ werd opgevat als louter onvoorzichtig gedrag. Daarmee was de verwijtbaarheid uit de culpa geëlimineerd en stemden het doleuze en het culpoze delict in zoverre qua opbouw overeen dat de verwijtbaarheid geen deel uitmaakte van de delictsomschrijving. Een beroep op een schulduitsluitingsgrond, immers een beroep op het ontbreken van verwijtbaarheid, vormde nu niet een bestrijding van de tenlastegelegde schuld, die immers louter bestond in onvoorzichtig gedrag, en de verwerping daarvan diende in die opvatting dus op grond van art. 358 lid 3 jo. 359 lid 2, eerste volzin, Sv uitdrukkelijk te geschieden en te worden gemotiveerd.

In deze opvatting werd afwezigheid van alle schuld, als strafuitsluitingsgrond erkend in het Water en melk-arrest (zie 3.I), dus gezien als het ontbreken van verwijtbaarheid in de vorm van vermijdbaarheid. Deze vermijdbaarheid vormde in die opvatting niet, zoals opzet of culpa, een bestanddeel van het delict - doch werd naast de bestanddelen van het delict gezien als een voorwaarde voor strafbaarheid. Een beroep op het ontbreken van deze schuld (een beroep op een schulduitsluitingsgrond) liet de bestanddelen opzet en culpa dus onverlet. Zo gezien was de uitspraak van de Hoge Raad in het Verpleegster-arrest niet verenigbaar met de erkenning van het 'geen straf zonder schuld' in het Water en melk-arrest. Daarbij werd er echter aan voorbijgegaan dat de Hoge Raad zich over de inhoud van de schuld in het Water en

456 HR ig februari ig63, NJ I963, 5I2, m.nt. B.V.A.R.

457 Zie thans art. 359 lid 2, tweede volzin, Sv. Van Eck oordeelde ten tijde van het Verpleegster-arrest reeds dat het door het Verpleegster-arrest aan het licht gekomen probleem kon worden opgevangen doordat de Hoge Raad van de rechter zou gaan eisen dat deze, indien hij een beroep op een schulduitsluitingsgrond bij een culpoos delict passeerde, dat uitdrukkelijk en gemotiveerd diende te doen.

$45^{8}$ Schuld in spiegelbeeld, p. 69 e.v. 
melk-arrest niet had uitgelaten en niet had overwogen dat het in het Water en melkarrest gehanteerde begrip schuld een ander begrip schuld was dan de wetgever had gebezigd in delictsomschrijvingen, zij het dat de Hoge Raad wél tot uitdrukking had gebracht dat straffeloosheid was aangewezen in geval iedere schuld - hetgeen in het licht van de wetsgeschiedenis (zie I.I) zou kunnen worden opgevat als culpa levis - ontbrak. 459

\subsection{Nog meer invloed van het strafproces(recht) op de inhoud van de culpa}

De in 3.6 besproken opvatting dat culpa diende te worden opgevat als niet meer dan uiterlijk onvoorzichtig gedrag, een opvatting waarin de culpa in wezen niet meer als subjectief bestanddeel kon worden aangemerkt, was mede geïnspireerd op de wijze waarop de bewijsvoering bij culpoze delicten plaatsvindt. Met name bij verkeersongevallen wordt de tenlastegelegde culpa uit uiterlijk onvoorzichtig gedrag - veelal handelen in strijd met enige verkeersregel - afgeleid. Waarom culpa dan niet zien als louter onvoorzichtig gedrag?

In die opvatting - een bewijsrechtelijke en niet een inhoudelijke benadering van de culpa - wordt er echter aan voorbijgegaan dat de gedachte achter het afleiden van de culpa uit uiterlijk onvoorzichtig gedrag is dat iemand die zich onvoorzichtig gedraagt behoudens aanwijzingen voor het tegendeel ook wel onvoorzichtig zal zijn geweest. Remmelink beschreef deze gedachte als 'het sprongetje om uit het objectief bezien gevaarlijke (onvoorzichtige) gedrag te concluderen tot subjectieve onvoorzichtigheid. ${ }^{460}$

De opvatting dat culpa zou bestaan in louter onvoorzichtig gedrag is in de rechtspraak dan ook niet gevolgd. Exemplarisch is het geval van de automobiliste die met haar auto na een flauwe bocht naar links op de linkerweghelft terechtkwam en daar op een tegemoetkomende auto botste waardoor de bestuurder van die auto zwaar gewond raakte. ${ }^{46 r}$ Vervolgd ter zake van zwaar lichamelijk letsel door schuld in het verkeer beriep zij zich erop dat zij op de weghelft van het tegemoetkomende verkeer terecht was gekomen omdat zij een black-out had gehad. Het hof was aan dit verweer voorbijgegaan. Dat achtte de Hoge Raad niet juist. Het onderhavige verkeersgedrag, aldus de Hoge Raad, kan in beginsel de gevolgtrekking dragen dat de verdachte zich aanmerkelijk onoplettend en/of onachtzaam heeft gedragen en dat het verkeersongeval aan de schuld van de verdachte als bedoeld in art. 6 van de Wegenverkeerswet 1994 te wijten is, maar: 'Dat kan in concreto evenwel anders zijn indien omstandigheden zijn aangevoerd en aannemelijk zijn geworden - bijvoorbeeld dat de verdachte ten tijde van het ongeval in verontschuldigbare onmacht verkeerde waaruit volgt dat van schuld in vorenbedoelde zin niet kan worden gesproken.' In een dergelijk geval, zo moet deze uitspraak worden begrepen, kan het 'sprongetje'

459 Zie hierover uitgebreid Schuld in spiegelbeeld, diss. Groningen I982.

460 J. Remmelink, Mr. D. Hazewinkel-Suringa's Inleiding tot de studie van het Nederlandse strafrecht, Arnhem: Gouda Quint bv I996, vijftiende druk, p. 239. Zie ook A.A. van Dijk, Strafrechtelijke aansprakelijkheid heroverwogen. Over opzet, schuld, schulduitsluitingsgronden en straf, diss. Groningen 2008, p. 62.

46I HR I juni 2004, LJN AO5822, NJ 2005, 252, m.nt. Kn. 
van uiterlijk gevaarzettend gedrag naar subjectieve schuld niet worden genomen. Doorgaans is uiterlijk gevaarzettend gedrag ${ }^{462}$ voor bewijs van de culpa voldoende, onder omstandigheden kan dit anders zijn. De culpa bestaat dus niet in louter uiterlijk onvoorzichtig gedrag.

\section{$4 \quad$ De (her)ontdekking van de mate van schuld}

\section{I Aanmerkelijke schuld als ondergrens van de culpa}

In de inleiding van dit preadvies is uiteengezet dat culpa niet louter bestaat in onvoorzichtigheid of onachtzaamheid maar in onvoorzichtigheid of onachtzaamheid in een min of meer grove of aanmerkelijke mate. Het vereiste van de mate van schuld heeft bij de ontwikkeling van de inhoud van de culpa in de literatuur geen rol van betekenis gespeeld. Ook in de rechtspraak is dit vereiste gedurende lange tijd op de achtergrond gebleven. Een uitzondering vormt het in I.I beschreven geval van het ongeval van de tram Heerenveen-Joure. Daar legde de Hoge Raad de nadruk op de voor culpa noodzakelijke min of meer grove of aanmerkelijke onachtzaamheid en constateerde dat daarvoor onvoldoende bewijs was. Tot een theoretische bezinning op de inhoud van dit vereiste heeft dit niet geleid terwijl ook uit de rechtspraak niet viel af te leiden wat het vereiste van de mate van schuld betekent. Uiteindelijk heeft niet de wetenschap maar de rechtspraak, in het bijzonder die van de Hoge Raad, hier het voortouw genomen, en wel in twee fasen, een eerste fase waarin nog eens uitdrukkelijk aan dit vereiste werd herinnerd, een tweede fase waarin ook enig houvast voor de ondergrens van de aanmerkelijke schuld werd gegeven.

\subsection{De Hoge Raad herinnert uitdrukkelijk aan de aanmerkelijke schuld}

Rond 1970 wees de Hoge Raad een aantal arresten waarin werd geoordeeld dat de bewezenverklaarde mate van schuld niet uit de gebezigde bewijsmiddelen kon worden afgeleid. In HR 9 mei 1967, NJ I968, 349 (Zegge) was de bestuurder met zijn auto zonder enige (verkeers)noodzaak plotseling naar rechts gezwenkt en tegen een in de berm staande boom gebotst ten gevolge waarvan een inzittende van de auto overleed. Ten laste van hem was bewezenverklaard dat hij 'hoogst roekeloos, onvoorzichtig, onoplettend en onachtzaam' tegen een rechts van de weg staande boom was gereden. Die bewoordingen, aldus de Hoge Raad, duidden op een mate van schuld waarvoor in de bewijsmiddelen geen steun was te vinden. HR 25 juni

462 In HR 22 april I969, VR I969, I20 (Sittardse inhaalmanoeuvre) bleek uit de bewijsmiddelen wel dat op de voor verdachtes linkerweghelft een botsing had plaatsgevonden van de door haar bestuurde auto met een tegemoetkomende auto, maar hoe deze botsing zich had toegedragen en of de verdachte zich dus gevaarzettend had gedragen was daaruit niet op te maken. De Hoge Raad oordeelde dat er onvoldoende bewijs was voor de culpa (onvoorzichtig inhalen) omdat uit de bewijsmiddelen niet viel af te leiden dat verdachte van haar wijze van rijden een verwijt kon worden gemaakt, in het bijzonder niet omdat uit die bewijsmiddelen niet kon worden afgeleid dat anders handelen voor de verdachte mogelijk was geweest. 
I968, VR I968, 77 (Aalsmeer) betrof een vergelijkbaar ongeval, met dien verstande dat de bestuurder na in de rechterberm te zijn geraakt naar links reed en op een tegemoetkomende auto botste. Het bewezenverklaarde 'hoogst onvoorzichtig, onoplettend en onachtzaam' duidde ook hier op een mate van schuld die eveneens niet uit de gebezigde bewijsmiddelen kon worden afgeleid. Opmerkelijk was dat de Hoge Raad er daarbij op wees dat de bewijsmiddelen de oorzaak van het in de rechterberm raken geheel in het duister lieten. Dat laatste sprong, voeg ik daaraan toe, temeer in het oog omdat de bestuurder wel een verklaring over het ongeval had afgelegd - eerst in de rechterberm terecht komen en dan in de linkerberm - doch, voor zover uit de gebezigde bewijsmiddelen valt op te maken, geen enkele verklaring voor deze wijze van rijden gaf. Het ontbreken van enige aanwijzing voor de oorzaak van het ongeval speelde ook een rol in HR 22 april I969, VR I969, I20 (Sittardse inhaalmanoeuvre) waarin niet meer vaststond dan dat de bestuurster van een auto rijdend op de voor haar linkerweghelft in botsing was gekomen met een tegemoetkomend voertuig waarvan de inzittenden ten gevolge van de botsing om het leven kwamen. Ten laste van de bestuurster was bewezenverklaard dat zij hoogst roekeloos had gereden. Daarvoor, aldus de Hoge Raad, was in de bewijsmiddelen geen aanknopingspunt te vinden. Nu uit de gebezigde bewijsmiddelen niet kon worden afgeleid dat anders handelen voor haar mogelijk was geweest, konden die bewijsmiddelen het oordeel niet dragen dat haar van haar wijze van rijden een verwijt kon worden gemaakt, laat staan een zodanig verwijt dat haar wijze van rijden als hoogst roekeloos kon worden aangemerkt. HR 8 november 1971, NJ 1972, 235 (Yde) betrof een bestuurster die bij duisternis met een auto tegen een geparkeerde vrachtwagen, voorzien van brandende achterverlichting, was gebotst met de dood van haar passagier als gevolg. Die feiten boden onvoldoende houvast voor een zodanig verwijt dat haar wijze van rijden als hoogst onvoorzichtig kon worden aangemerkt. In de zaak van de Haarlemse rechter (HR I3 oktober 1970, NJ 197I, 3I) ten slotte oordeelde de Hoge Raad dat uit de gebezigde bewijsmiddelen niet bleek dat de verdachte onder de in de bewezenverklaring beschreven omstandigheden - nat wegdek, banden in slechte staat - in ernstige mate onvoorzichtig had gereden. De bestuurder was met zijn auto geslipt en tegen een tegemoetkomende bromfietser gebotst; hij reed ca. $40 \mathrm{~km} / \mathrm{u}$ en had tevoren een glas tomatensap met wodka gedronken, ten tijde van het ongeval resulterend in een bloedalcoholgehalte van o, 6 promille. ${ }^{463}$

Deze uitspraken veroorzaakten in de praktijk en de literatuur enige onrust. Deze vond zijn oorsprong niet zozeer in het geprononceerd door de Hoge Raad op de agenda zetten van de vereiste mate van schuld. Het was wel duidelijk dat de Hoge Raad hechtte aan het serieus nemen van de in de tenlastelegging opgenomen mate van schuld. Het was dus niet verstandig zonder meer te kiezen voor een zeer zware graad van schuld als daarvoor in de voorhanden bewijsmiddelen onvoldoende steun viel te vinden. ${ }^{64}$ In een van de genoemde arresten - HR 22 april I969, VR I969, I20 (Sittardse inhaalmanoeuvre) - overwoog de Hoge Raad echter dat aan het bewijs van de schuld in de weg stond dat uit de gebezigde bewijsmiddelen niet kon worden

463 o, I promille boven de wettelijke grens.

464 O.a. J.M.A.V. Moons, VR I970, p. 53. 
afgeleid dat anders handelen voor de verdachte mogelijk was geweest. Dit riep de vraag op of steeds expliciet uit de gebezigde bewijsmiddelen moest blijken dat anders handelen voor de verdachte mogelijk was geweest. Zou dit het geval zijn, dan kon men, aldus G.E. Mulder, ${ }^{465}$ de vervolging van culpoze delicten wel staken. Reeds spoedig bleek dat dit niet het geval was. In HR II april 1972, NJ I972, 24I (Apeldoornse voetganger) was de bestuurder veroordeeld omdat hij met een min of meer grove of aanmerkelijke onachtzaamheid was aangereden tegen de meest linkse van twee voor hem uit lopende, plotseling door hem waargenomen voetgangers waardoor een van deze voetgangers ernstig gewond raakte. Uit de bewijsmiddelen bleek dat de bestuurder bij nacht had gereden met een snelheid van 40 à $50 \mathrm{~km} / \mathrm{u}$ met gedimd groot licht over een door de openbare straatverlichting goed verlichte weg, dat de voor hem uit lopende voetgangers plotseling door hem waren waargenomen en dat hij direct daarop tegen een van deze voetgangers was aangereden. Verbazing hoeft deze uitspraak niet te wekken. In de woorden van de advocaat-generaal Remmelink: 'Wie op een goed verlichte weg rijdende met een snelheid van 40 à $50 \mathrm{~km}$ per uur een voor hem uitlopende voetganger aanrijdt, terwijl niet blijkt van vreemde capriolen van deze laatste noch van andere ongunstige omstandigheden (druk tegenliggend verkeer, gladheid enz.), zal geredelijk gezegd kunnen worden aanmerkelijk onoplettend te zijn geweest.' Daarbij kon het bewijs van het anders kunnen handelen kennelijk in de gebezigde bewijsmiddelen besloten worden geacht, omdat uit de verklaring van de niet-aangereden voetganger bleek dat men gewoon aan de kant van de weg liep (en dus geen rare capriolen uithaalde) en in wezen in het relaas van de bestuurder het gebrek aan oplettendheid (plotseling waarnemen van door openbare straatverlichting goed zichtbare voetgangers) als oorzaak van het ongeval besloten lag.

Kort nadat dit arrest was gewezen bleek dat de Hoge Raad inderdaad aan het bewijs van het anders kunnen handelen niet extreem hoge eisen stelde. Toen een bestuurder, die 's nachts, rijdend onder invloed van alcoholhoudende drank, op een zebra in Den Haag met zijn auto een voetganger had geschept waardoor deze dodelijk gewond rakkte, er bij veroordeling ter zake van dood door schuld (in de vorm van - volgens de Hoge Raad - aanmerkelijk onvoorzichtig onvoldoende oplettend) in cassatie op wees dat de bewijsmiddelen niet uitsloten dat de voetganger voor verdachte onverwacht hardlopend de weg was overgestoken of zich enige andere omstandigheid had voorgedaan waardoor de verdachte het ongeluk niet had kunnen voorkomen, vond hij bij de Hoge Raad allesbehalve gehoor. ${ }^{466}$ Naar het oordeel van de Hoge Raad had het hof de mogelijkheid van het zich voorgedaan hebben van zulk een omstandigheid, gelet op de inhoud der gebezigde bewijsmiddelen in onderling verband beschouwd - voor wat een hardlopen van het slachtoffer betreft in het bijzonder gelet op zijn hoge leeftijd (72 jaar) - als zo onwaarschijnlijk kunnen

465 Noot bij HR 22 april I969, AA I970, p. 218 e.v.

466 HR 3 april I973, NJ I973, 283, m.nt. ThWvV (dronken caféhouder). 
aanmerken, dat het hof deze bij de bewijsvoering zonder meer terzijde mocht stellen. ${ }^{467}$

Met deze uitspraken was het patroon voor het bewijs van de culpa voor de eerstvolgende jaren uitgelegd. Decennia lang leverde het bewijs van de culpa in cassatie nauwelijks problemen op. Een enkele uitzondering daarop vormde bijvoorbeeld ${ }^{468}$ HR I6 november I999, VR 2000, 35. Dit arrest betrof een geval waarbij verdachte op een voetgangersoversteekplaats binnen de bebouwde kom, rijdend op de linker rijstrook van twee rijstroken voor verkeer in dezelfde richting met een hogere snelheid dan de ter plaatse toegestane snelheid van $50 \mathrm{~km} / \mathrm{u}$, te weten ten minste $60 \mathrm{~km} / \mathrm{u}$, een voetganger had geschept. Hij beriep zich erop dat de voetganger op een holletje de voetgangersoversteekplaats was opgelopen en dat het zicht op de voetgangersoversteekplaats voor hem werd belemmerd door een voor hem rijdende vrachtwagen en een rechts voor hem rijdende personenauto. Het hof had dit verweer niet onbesproken mogen laten omdat het had dienen na te gaan of ondanks de gestelde feiten, zoal juist, diende te worden gesproken van de bewezenverklaarde aanmerkelijke verwaarlozing van de geboden voorzichtigheid. Een inbreuk op het door de Hoge Raad uitgelegde patroon vormt deze uitspraak niet. Zou immers juist zijn geweest hetgeen de verdachte aanvoerde dan deed dit af aan de ernst van zijn onvoorzichtigheid en zou zelfs de vraag in beeld kunnen komen of hij redelijkerwijs anders had kunnen handelen.

Dat het bewijs van de culpa - ondanks de aanvankelijk als alarmerend opgevatte, hiervoor beschreven vijf uitspraken van de Hoge Raad ('Zegge', 'Aalsmeer', 'Sittardse inhaalmanoeuvre', 'Yde', 'Haarlemse rechter') - weinig problemen opleverde, valt tot op zekere hoogte ongetwijfeld toe te schrijven aan het feit dat duidelijk was dat majoreren van de mate van schuld tot problemen aanleiding zou geven en dus niet te snel voor een te zware schuldvorm moest worden gekozen. Toch kan toeval hier ook een rol hebben gespeeld. Zolang immers een zaak niet aan de Hoge Raad wordt voorgelegd kan deze zich daarover ook niet uitlaten.

In hoeverre de rechtspraak van de Hoge Raad invloed heeft gehad op het vervolgingsbeleid valt niet na te gaan. Vervolgings- en requireerrichtlijnen bestonden toentertijd nog niet. Niettemin is het niet te gewaagd te veronderstellen dat die rechtspraak ook bij vervolgingsbeslissingen een rol ging spelen.

\subsection{Ongerustheid in de literatuur}

Omstreeks het jaar 2000, dus ongeveer drie decennia na de besproken vijf opmerkelijke culpa-arresten, kwam in de literatuur de vraag op of de culpa niet uitgehold was geraakt doordat de enkele verkeersovertreding voldoende leek te zijn voor het aannemen van culpa. Otte maakte gewag van een juridisch en gedragswetenschappelijk onderzoek waarbij werd gevonden dat in bijna de helft van de I20 onderzochte

467 Dit arrest past binnen de eisen die de Hoge Raad ook nu nog stelt aan de aandacht die de rechter moet schenken aan een beroep op een alternatief scenario: HR 26 maart 20I0, LJN BK3359, NJ 20I0, 3I4, m.nt. Y. Buruma, rov. 2.5.

468 Zie ook HR I8 oktober I988, VR I990, 37. 
veroordelingen ter zake van art. 6 WVW 1994 een enkele verkeersovertreding voldoende was voor een veroordeling. Hij zag dit onderzoeksresultaat bevestigd in de onder door hem gesproken officieren van justitie overwegend levende opvatting dat een enkele verkeersovertreding voldoende is om te komen tot bewijs van de voor art. 6 WVW 1994 vereiste culpa en meldde dat zij deze opvatting zagen bevestigd in door rechters uitgesproken 'gave' veroordelingen. ${ }^{469}$ De Jong ${ }^{470}$ las de rechtspraak van de Hoge Raad zo dat er sprake is van een culpoos misdrijf wanneer een verkeersovertreding heeft geresulteerd in een voor een ander fataal ongeval. Hij meende dat deze rechtspraak was ingezet met het Verpleegster-arrest (HR ig februari ig63, NJ I963, 512). Van die door hem aldus verstane rechtspraak toonde hij zich overigens een overtuigd tegenstander. ${ }^{471}$ Ook andere auteurs waarschuwden voor deze uitholling van de schuld. ${ }^{472}$ De Hullu meldde dat bij sommige feitenrechters als beleidslijn werd gehanteerd dat voor verkeersschuld zeker twee overtredingen van verkeersvoorschriften moesten zijn vastgesteld. ${ }^{473}$

\subsection{De Hoge Raad herinnert opnieuw én uitdrukkelijk aan het aanmerkelijke van de schuld}

Hoewel naar mijn mening uit de rechtspraak van de Hoge Raad niet viel op te maken dat de enkele verkeersovertreding met fataal gevolg voldoende was voor het aannemen van de vereiste merkelijke schuld, ${ }^{474} \mathrm{zag}$ de Hoge Raad toch reden in zijn arrest van I juni 2004, LJN AO5822, NJ 2005, 252, m.nt. G. Knigge (Winssen) enkele piketpalen 475 te slaan ter adstructie van het bewijs van de schuld. Reden voor ongerustheid over de wijze waarop in de praktijk met het vereiste van de aanmerkelijke schuld werd omgegaan was er immers wel. ${ }^{476}$ Aan die ongerustheid werd ook voedsel

469 Trema Straftoemetingsbulletin 2003, p. $5 \mathrm{I}$.

470 Delikt en Delinkwent I999, p. 5. De Jong beschrijft een ontwikkeling naar een situatie waarin de culpa (vrijwel) gelijkstaat aan een enkele overtreding uitgebreider in De inwendige en de normatieve component van opzet en culpa, Trema 2004, p. I-7. In Delikt en Delinkwent I999, p. 832 e.v. verdedigt hij dat de door hem gesignaleerde gelijkstelling van de culpa met het enkele begaan van een overtreding dient te leiden tot herijking van de figuur van de aanmerkelijke schuld. Zo ook Otte, a.w., p. 4. In vergelijkbare zin Buruma in de bundel Verwijtbare uitholling van schuld, Ars Aequi I998, p. 6.

47I Trema 2004, p. 7 .

472 Zie Buruma en Borgers in de bundel Verwijtbare uitholling van schuld, Ars Aequi I998, en Otte in zijn oratie Opzet en schuld in het verkeer, Gouda Quint 200I, p. 4.

473 J. de Hullu, Materieel strafrecht, tweede druk, p. 265. In latere drukken vermeldt De Hullu dit niet meer.

474 Kortheidshalve verwijs ik naar de conclusie bij HR I juni 2004, LJN AO5822, NJ 2005, 252, m.nt. G. Knigge, punten I2-I5. Zie ook Lensing, Verkeersrecht 200I, p. 277, die uit zijn praktijk bij de berechting in eerste aanleg niet de indruk had gekregen dat de enkele verkeersovertreding voor schuld in de zin van art. 6 WVW 1994 volstaat.

475 Van Dijk, a.w., p. 35, stelt dat dit een van de meest veelzeggende uitspraken is van de Hoge Raad die zich kenmerkt door nietszeggendheid. Ten onrechte abstraheert hij geheel van het probleem dat voorlag alsmede van bestaande rechtspraak. Op p. Igo bestempelt hij de vraag naar de aanmerkelijkheid van de schuld als een woordenspel, daarmee ten onrechte abstraherend van de lijnen die in de rechtspraak van de Hoge Raad - zie o, o, o en o-opgesloten liggen.

476 Zie daarover ook de conclusie bij genoemd arrest onder 9 e.v. 
gegeven door de per I april 2004 in werking getreden (inmiddels vervallen ${ }^{477}$ ) Aanwijzing artikel 6 wegenverkeerswet $1994 .{ }^{478}$ In deze van het College van procureursgeneraal afkomstige, tot de leden van het Openbaar Ministerie gerichte, Aanwijzing werd als lichtste onder art. 6 WVW 1994 te begrijpen vorm van schuld genoemd 'aanmerkelijke verkeersfouten'. Daarbij werd gedacht 'aan situaties waarin een fout gemaakt wordt die op grond van de maatschappelijke verantwoordelijkheid - in de literatuur "Garantenstellung" genoemd - van de verkeersdeelnemer niet gemaakt had mogen worden. In deze gevallen is vaak sprake van het door de verkeersdeelnemer niet waarnemen van de andere weggebruiker of het niet hebben ingeschat van het eventuele risico dat zal ontstaan door een bepaalde handeling.' Vervolgens werd gesteld dat het geen voorrang verlenen aan een op een voorrangsweg rijdende, voor de voorrangsplichtige bestuurder waarneembare motorrijder, een voorbeeld van deze lichtste schuldvorm, een weliswaar op zichzelf voorstelbare fout was, maar dat deze niettemin tot vervolging diende te leiden omdat daarmee het veiligheidsbelang van de naleving van verkeersregels werd onderstreept. Daarbij werd erop gewezen dat juist vanwege de ernst van de gevolgen het achterwege laten van vervolging een klacht ex art. I2 Sv ${ }^{479}$ kon meebrengen alsmede dat 'bedoelde fouten die iedereen kan maken' met inachtneming van alle betrokken belangen dienden te worden beoordeeld. Omdat in het voorbeeld van de motorrijder, een weggebruiker die door zijn beperkte waarneembaarheid nog wel eens over het hoofd wordt gezien, kennelijk de enkele voorrangsfout voor de culpa voldoende werd geacht, leek de Aanwijzing in belangrijke mate te neigen naar de gedachte dat de enkele verkeersfout de vereiste mate van schuld oplevert.

Terug naar het arrest 'Winssen'. In deze zaak was de vraag aan de orde of de bestuurster van een Ford Mondeo aanmerkelijk onoplettend en/of onachtzaam had gereden doordat zij na een voor haar naar links lopende bocht geheel of gedeeltelijk op de linkerweghelft terecht was gekomen waardoor zij met haar auto tegen een haar tegemoetkomende Mazda was gebotst ten gevolge waarvan de bestuurster van de Mazda zwaar gewond raakte. Bij de beantwoording van deze vraag stelde de Hoge Raad voorop dat in cassatie slechts kan worden getoetst of de bewezenverklaarde schuld uit de gebezigde bewijsmiddelen kan worden afgeleid. Daarbij, aldus de Hoge Raad, komt het aan op het geheel van gedragingen van de verdachte, de aard en ernst daarvan en de overige omstandigheden van het geval.

Dat laatste bracht de Hoge Raad tot het oordeel dat niet in zijn algemeenheid valt aan te geven of één verkeersovertreding voldoende kan zijn voor de bewezenverklaring van schuld in de zin van evenbedoelde bepaling. Daarvoor zijn immers - aldus de Hoge Raad - verschillende factoren van belang, zoals de aard en de concrete ernst van de verkeersovertreding en de omstandigheden waaronder die overtreding

477 Thans is van toepassing de Richtlijn voor strafvordering verkeersongevallen d.d. 29 november 20II, Stcrt. 20II, nr. 228I7, in werking getreden I januari 20I2. Daarin wordt wel gesproken van het maken van een aanmerkelijke verkeersfout, doch wordt deze niet verder omschreven.

478 Aanwijzing in de zin van art. I30 lid 4 Wet RO d.d. Io februari 2004, Stcrt. 2004 d.d. 27 februari 2004, nr. 40, p. 9.

479 Door een belanghebbende bij het hof in te dienen klacht wegens het niet vervolgen van een strafbaar feit. 
is begaan. Met andere woorden, een enkele overtreding levert niet zonder meer ${ }^{480}$ aanmerkelijke schuld op, dat hangt af van verschillende factoren, zoals de aard en de concrete ernst van de verkeersovertreding en de omstandigheden waaronder die overtreding is begaan. Daar voegde de Hoge Raad aan toe dat niet reeds uit de ernst van de gevolgen van verkeersgedrag dat in strijd is met één of meer wettelijke gedragsregels in het verkeer, kan worden afgeleid dat sprake is van schuld in vorenbedoelde zin.

Over het te berechten geval overwoog de Hoge Raad vervolgens:

\begin{abstract}
'3.6. Het Hof heeft blijkens de gebezigde bewijsmiddelen vastgesteld dat de verdachte als bestuurster van een personenauto, rijdend met een snelheid van ongeveer $80 \mathrm{~km}$ per uur op een tweebaansweg, na een flauwe bocht naar links niet zoveel mogelijk rechts heeft gehouden maar plotseling zonder enige aanleiding, zo ver naar links is gekomen dat zij daardoor op de verkeerde weghelft is terechtgekomen en daar frontaal in botsing is gekomen met een op die andere weghelft rijdende tegenligger. Zodanig verkeersgedrag kan in beginsel de gevolgtrekking dragen dat de verdachte zich aanmerkelijk onoplettend en/of onachtzaam heeft gedragen en dat het verkeersongeval aan de schuld van de verdachte als bedoeld in art. 6 van de Wegenverkeerswet 1994 te wijten is. Dat kan in concreto evenwel anders zijn indien omstandigheden zijn aangevoerd en aannemelijk zijn geworden - bijvoorbeeld dat de verdachte ten tijde van het ongeval in verontschuldigbare onmacht verkeerde - waaruit volgt dat van schuld in vorenbedoelde zin niet kan worden gesproken.'
\end{abstract}

In de kern van de zaak had de verdachte slechts een enkele verkeersovertreding begaan: anders dan art. 3 RVV I99o voorschrijft niet zoveel mogelijk rechts houden. Deze overtreding was echter begaan onder zodanige omstandigheden - rijdend met een snelheid van $80 \mathrm{~km} / \mathrm{u}$, tweebaansweg (dus tegemoetkomend verkeer te verwachten), na een flauwe bocht naar links, plotseling, zonder enige aanleiding - en op zodanige wijze - zover naar links gaan dat botsing met tegenligger volgde - dat daaruit (in beginsel) de bewezenverklaarde culpa kon worden afgeleid.

De aangehaalde overweging laat ook zien dat nog steeds uit de uiterlijke gevaarzettende gedraging de culpa kan worden afgeleid, doch dat dat - de Hoge Raad spreekt van 'in beginsel' - onder omstandigheden anders kan zijn. Voorts zien we dat de Hoge Raad naast elkaar overweegt dat uit de gebezigde bewijsmiddelen kan worden afgeleid:

480 Anders R. Robroek, Onbewuste culpa. Een analyse van de ondergrens van de strafrechtelijke aansprakelijkheid, Tilburg: Celsus juridische uitgeverij 20I0, p. I23, die het arrest van de Hoge Raad zo uitlegt dat de enkele verkeersovertreding in principe voldoende is voor het bewijs van de culpa, daarbij miskennend dat de Hoge Raad erop wijst dat daarvoor verschillende factoren van belang zijn waaronder de aard en de concrete ernst van die overtreding. De Hoge Raad sluit niet uit dat de enkele verkeersovertreding in de omstandigheden van het geval voldoende bewijs voor de culpa oplevert, maar daarmee kan deze uitzondering nog niet, zoals Robroek doet, tot regel worden gemaakt. 
a. dat de verdachte zich aanmerkelijk onoplettend en/of onachtzaam heeft gedragen, én

b. dat het verkeersongeval aan de schuld van de verdachte als bedoeld in art. 6 van de Wegenverkeerswet 1994 te wijten is.

Met een en ander wordt nog eens bevestigd dat de culpa uit uiterlijk onvoorzichtig gedrag kan worden afgeleid, maar deze niet aan uiterlijk onvoorzichtig gedrag gelijk staat.

Als voorbeeld van een geval waarin uit uiterlijk onvoorzichtig gedrag als het onderhavige de culpa niet kan worden afgeleid noemt de Hoge Raad het geval dat de verdachte ten tijde van het ongeval in verontschuldigbare onmacht verkeerde. Dat voorbeeld vond zijn oorsprong in verdachtes voor het bewijs gebezigde verklaring dat zij ter plaatse in een zeer flauwe bocht naar links mee naar links de bocht in had gestuurd maar toen een soort black-out had gehad, kennelijk niet meer naar rechts had gestuurd en zo op de voor haar linkerweghelft terecht was gekomen. Hoe die verklaring aan het bewijs van de culpa kon bijdragen achtte de Hoge Raad zonder nadere motivering niet begrijpelijk: 'Die verklaring strekt immers onmiskenbaar ten betoge dat het de verdachte tengevolge van die plotseling opgekomen en voor haar onvoorzienbare black-out niet te verwijten is dat zij haar voertuig korte tijd niet onder controle had en gedurende die tijdsspanne op de andere weghelft is terechtgekomen.' Het zou zo kunnen zijn dat die black-out wel voor rekening van de verdachte kwam en haar kon worden verweten, maar daarover bevatte de uitspraak van het hof niets.

\subsection{Aanmerkelijke schuld en momentane onoplettendheid}

Op 9 april 2005 deed zich te Geervliet een ernstig ongeval voor. Een automobilist reed vanaf een langs de weg gelegen tankstation een weg voor verkeer uit beide richtingen op. Hij bracht zijn auto daarbij, in de wetenschap dat hij het op de weg rijdende verkeer voorrang moest verlenen, voor de haaientanden vrijwel tot stilstand, keek over zijn linkerschouder, had daarbij onbelemmerd uitzicht, zag geen verkeer naderen, reed de weg op en hoorde na een twintigtal meters een harde klap. Een motorrijdster, die hem met een ter plaatse toegelaten snelheid van $80 \mathrm{~km} / \mathrm{u}$ achterop reed, had zijn auto niet meer kunnen ontwijken en was op zijn auto gebotst. Zij raakte daarbij zeer zwaar gewond. De automobilist werd op grond van deze feiten veroordeeld voor zwaar lichamelijk letsel door schuld in het verkeer (art. 6 WVW I994). In cassatie (HR 29 april 2008, LJN BD0544) ${ }^{48 \mathrm{r}} \mathrm{kwam}$ de vraag aan de orde of de verdachte, zoals was bewezenverklaard 'aanmerkelijk onoplettend en met aanmerkelijke verwaarlozing van de te dezen geboden zorgvuldigheid heeft gereden'. Nadat de Hoge Raad zijn algemene beschouwingen over het bewijs van de schuld, als opgenomen in 'Winssen' had herhaald oordeelde de Hoge Raad dat dit niet het geval was: 'Anders dan het Hof kennelijk heeft geoordeeld, kan uit de enkele omstandigheid dat de verdachte, toen hij zich vergewiste van mogelijk naderend verkeer, de

48I NJ 2008, 440 met noot N. Keijzer onder NJ 2008, 442. 
motorrijdster aan wie hij voorrang diende te verlenen niet heeft gezien hoewel deze voor hem wel zichtbaar moet zijn geweest, niet volgen dat de verdachte, zoals is bewezenverklaard "aanmerkelijk onoplettend en met aanmerkelijke verwaarlozing van de te dezen geboden zorgvuldigheid heeft gereden."'

In HR 27 mei 2008, LJN BC7860482 was eveneens aanmerkelijke schuld in de lichtste vorm (aanmerkelijk onvoorzichtig en onoplettend) bewezenverklaard en achtte de Hoge Raad het enkele over het hoofd zien van een fietser aan wie voorrang moest worden verleend in de omstandigheden van het geval niet toereikend voor het bewijs van de aanmerkelijke schuld. Dat oordeel volgde ook in het geval een automobilist bij het linksaf slaan een tegemoetkomende motorrijder over het hoofd zag hoewel deze voor hem waarneembaar moest zijn geweest en hij zijn rijgedrag daarop had moeten kunnen afstemmen (HR 28 oktober 2008, LJN BE9800483).

Men zou dus kunnen zeggen dat de enkele momentane onoplettendheid - wel kijken, niet zien, verkeerd kijken en dus niet zien - geen aanmerkelijke schuld oplevert. Daarmee heeft de Hoge Raad niet alleen bevestigd dat het vereiste van de aanmerkelijkheid van de schuld serieus moet worden genomen, maar ook een nadere invulling gegeven aan de ondergrens van de aanmerkelijke schuld. We weten nu niet alleen dat de enkele verkeersovertreding niet zonder meer aanmerkelijke schuld oplevert, maar ook dat een verkeersovertreding geen aanmerkelijke schuld oplevert wanneer deze valt toe te schrijven aan momentane, hoewel essentiële onoplettendheid. ${ }^{48}$ Daarmee lijkt ook het in 3.7 besproken Verpleegster-arrest achterhaald in die zin dat thans hogere eisen aan het bestaan van de aanmerkelijke schuld worden gesteld dan in dat arrest besloten lag.

\subsection{Aanmerkelijke schuld buiten het wegverkeer}

De accentuering en uitwerking van de vereiste aanmerkelijkheid der schuld heeft plaatsgevonden in zaken van wegverkeer. De vraag rijst daarom of deze ontwikkeling zijn sporen ook heeft getrokken ten aanzien van andere culpoze (gevolgs)delicten dan dood en zwaar lichamelijk letsel door schuld in het verkeer. Dat is inderdaad het geval. In HR 30 november 20I0, LJN BN7726485 was de verdachte veroordeeld ter zake van zwaar lichamelijk letsel door schuld omdat hij in een kantine op een tafel was gesprongen en er meteen weer af, daarbij met zijn knie een van zijn tafelgenoten in het gezicht rakend met zwaar lichamelijk letsel als gevolg. De Hoge Raad oordeelde dat uit de enkele omstandigheid dat de verdachte op de tafel was gesprongen en daarvan vervolgens weer was afgesprongen, niet zonder meer kon volgen dat de verdachte, zoals bewezenverklaard, zich 'aanmerkelijk onvoorzichtig' had gedragen. HR 29 juni 2010, LJN BL5630486 (kampvuur Castricum) betrof het geval van een leraar die tijdens een schoolkampweekend wasbenzine sprenkelde op een

482 NJ 2008, 44I met noot N. Keijzer onder NJ 2008, 442.

483 NJ 2008, 442, met noot N. Keijzer.

484 In het Duitse recht wordt deze lichte vorm van culpa wel aangeduid als 'einfacher Fahrlässigkeit': Kristian Kühl, Strafrecht Allgemeiner Teil, München: Verlag Franz Vahlen 2008, p. 525.

485 NJ 20I0, 675, m.nt. P.A.M. Mevis.

486 NJ 2010, 674, m.nt. P.A.M. Mevis. 
kampvuur om te voorkomen dat het zou doven. Er volgde een steekvlam waardoor diverse leerlingen ernstig gewond raakten. Deskundigen verklaarden dat tijdens door hen uitgevoerde tests waargenomen fysische effecten - in het bijzonder ook de horizontale steekvlam die was ontstaan - vóóraf door hen niet waren voorzien en dat de effecten hen hadden verrast. Het hof sprak de verdachte vrij van zwaar lichamelijk letsel door schuld, in de tenlastelegging voor wat betreft de laagste graad verwoord als 'aanmerkelijk, onvoorzichtig en/of onoplettend', omdat verdachte weliswaar onvoorzichtig was geweest door in strijd met de waarschuwingen op de fles toch wasbenzine op open vuur te sprenkelen, doch gelet op de bevindingen van de deskundigen niet kon worden gezegd dat verdachte op grond daarvan een zodanig strafrechtelijk verwijt kon worden gemaakt dat dit schuld in strafrechtelijke zin met betrekking tot de tenlastegelegde gevolgen opleverde. De Hoge $\operatorname{Raad}^{487}$ overwoog:

'2.4 (...) Onder schuld als delictsbestanddeel wordt een min of meer grove of aanmerkelijke schuld verstaan. Of sprake is van dergelijke schuld in de zin van art. 308 Sr wordt bepaald door de manier waarop die schuld in de tenlastelegging nader is geconcretiseerd, en is voorts afhankelijk van het geheel van de gedragingen van de verdachte, de aard en de ernst daarvan en de overige omstandigheden van het geval.

2.5. 's Hofs overwegingen moeten aldus worden begrepen dat het Hof heeft geoordeeld dat de verdachte weliswaar onvoorzichtig heeft gehandeld, doch niet dat hij - mede in aanmerking genomen dat niet gezegd kan worden dat hij de gevolgen van zijn handelen had kunnen en moeten voorzien - zich "roekeloos, in elk geval zeer, althans aanmerkelijk, onvoorzichtig en/of onoplettend" heeft gedragen, zoals is tenlastegelegd. Anders dan het middel betoogt, blijkt uit 's Hofs overwegingen niet van een onjuiste rechtsopvatting, in het bijzonder niet wat betreft het begrip "schuld" in de zin van art. $308 \mathrm{Sr}$.'

In deze laatste zaak vestigt de Hoge Raad uitdrukkelijk de aandacht op het belang van de wijze waarop de culpa is tenlastegelegd. Uiteindelijk bepaalt niet de vraag of sprake is van aanmerkelijke schuld maar de vraag of sprake is van aanmerkelijke schuld in de vorm waarin deze is tenlastegelegd, of de culpa kan worden bewezen. Voorts strookt de overweging dat het feit dat de verdachte onvoorzichtig heeft gehandeld nog niet betekent dat daarmee de culpa, zoals tenlastegelegd, gegeven is, met de hiervoor besproken uitspraken betreffende het wegverkeer waarin werd geoordeeld dat met een enkele overtreding of een enkele onoplettendheid nog niet aanmerkelijke schuld is gegeven. In casu speelde daarbij onder meer een rol dat - kennelijk in het licht van de bevindingen en de kennis van de deskundigen niet gezegd kon worden dat verdachte de gevolgen van zijn handelen had kunnen en moeten voorzien. Daarmee zien we de voorzienbaarheid als kern van de culpa, die bij culpa in het wegverkeer door een veelheid van uit de voorzienbaarheid voortvloeiende veiligheidsvoorschriften op de achtergrond is geraakt, weer tevoorschijn komen.

487 Zie ook HR 7 februari 20I2, LJN BU2878, NJ 20I2, II9 (klimwand) en HR I2 juni 20I2, LJN BW7948 (landmachtdemonstratie). 
HR I2 juni 20I2, LJN BW7948 had betrekking op een ongeval dat plaatsvond op een open dag van de Koninklijke Landmacht. Tijdens die open dag werd een demonstratie gehouden waarbij vier militairen van de Luchtmobiele Brigade vanuit een Lynx helikopter vanaf 30 meter hoogte aan een touw afdaalden. Toen de militairen waren afgedaald vloog de helikoper weg, terwijl de afdaallijn van een van de militairen niet van de helikopter en evenmin van de militair zelf was losgekomen. Deze militair werd meegesleurd en overleed aan de gevolgen daarvan. Verdachte werd vervolgd voor dood door schuld omdat hij als boordwerktuigkundige/loadmaster niet had gezorgd dat alle afdaaltouwen waren losgesneden van de helikopter voordat hij het sein gaf dat kon worden weggevlogen. Hij werd vrijgesproken van de tenlastegelegde min of meer grove of aanmerkelijke schuld omdat de door hem gemaakte fout in belangrijke mate mede in de hand was gewerkt door 'de organisatorische omgeving waarin hij zijn werkzaamheden moest verrichten' en dat het in die omstandigheden te ver ging om de verdachte de door hem gemaakte fout in strafrechtelijke zin aan te rekenen als grof of aanmerkelijk onachtzaam of nalatig. Dit oordeel, aldus verstaan dat volgens het hof wegens het ontbreken van voldoende verwijtbaarheid ${ }^{488}$ geen sprake was van min of meer grove of aanmerkelijke schuld als in de tenlastelegging omschreven, werd door de Hoge Raad niet onaanvaardbaar geacht.

\section{$5 \quad$ De invulling van de aanmerkelijkheid van de schuld}

\section{I Inleiding}

Het antwoord op de vraag of iemand aansprakelijk kan worden gesteld voor het veroorzaken van dood of zwaar lichamelijk letsel van een ander wordt, voor zover geen sprake is van opzet op het veroorzaken van de dood of het toebrengen van zwaar lichamelijk letsel, bepaald door het oordeel of die dood of dat letsel kan worden toegeschreven aan minstgenomen aanmerkelijke onvoorzichtigheid of onachtzaamheid. Doorgaans zal enige onvoorzichtigheid of onachtzaamheid eenvoudig zijn aan te wijzen. Het is echter niet eenvoudig om te beslissen of aan die onvoorzichtigheid of onachtzaamheid zo zwaar moet worden getild dat deze als aanmerkelijk moet worden betiteld. Dat oordeel impliceert immers dat iemand zich aan een ernstig misdrijf heeft schuldig gemaakt. In de praktijk blijken bij de beantwoording van de vraag naar de aanmerkelijkheid van de schuld heel verschillende uitgangspunten te worden gekozen. Soms wordt geoordeeld dat het gevolg van de onvoorzichtigheid of onachtzaamheid zo groot is dat deze wel aanmerkelijk moet zijn geweest, soms wordt geoordeeld dat van aanmerkelijke onvoorzichtigheid of onachtzaamheid niet

488 Met dit niet verder omschreven, wat verwarrende begrip 'onvoldoende verwijtbaarheid' beoogde de Hoge Raad kennelijk tot uitdrukking te brengen dat de verdachte niet een zodanig groot verwijt van de tenlastegelegde onvoorzichtigheid, onachtzaamheid of nalatigheid viel te maken dat dit als min of meer grove of aanmerkelijke schuld kon worden aangemerkt. Zo ook ten aanzien van gebruik van hetzelfde begrip in HR 7 februari 20I2, LJN BU2878, NJ 20I2, II9 (klimwand). 
kan worden gesproken omdat 'ieder' die onvoorzichtigheid of onachtzaamheid had kunnen overkomen etc. Op de achtergrond speelt daarbij soms twijfel aan de rechtvaardiging van de bestraffing van culpoze delicten een rol. Bij de aansprakelijkheidstelling voor het veroorzaken van dood of zwaar lichamelijk letsel van een ander komt het in de kern van de zaak dus aan op de vraag of de onvoorzichtigheid of onachtzaamheid aanmerkelijk was.

Er is geen reden aan te nemen dat dit ten aanzien van het aannemen van culpa met betrekking tot andere gevolgen of omstandigheden anders zal liggen. Typerend is in dit verband hoe snel feitenrechters bij vervolging voor schuldheling aannemen dat een verdachte schuld heeft aan het afkomstig zijn van misdrijf van onder hem aangetroffen gestolen goederen. Enige onachtzaamheid valt snel aan te nemen, het aanmerkelijke van die onachtzaamheid niet. Met regelmaat moet de Hoge Raad hier ingrijpen. ${ }^{489}$

Bij de vraag naar de culpa ligt de nadruk dus in het merendeel van de gevallen niet op de onvoorzichtigheid of onachtzaamheid maar op het aanmerkelijke daarvan. Dat bepaalt uiteindelijk of iemand zich aan een (culpoos) misdrijf heeft schuldiggemaakt.

\subsection{Karakter van de eis van de aanmerkelijkheid van de schuld}

Heeft iemands aanmerkelijke onoplettendheid of onvoorzichtigheid ernstige gevolgen - dood (art. $307 \mathrm{Sr}$ ), zwaar lichamelijk letsel (art. $308 \mathrm{Sr}$ ) brand (art. I58 Sr), vernieling van een elektriciteitswerk (art. I6Iter Sr) - dan betekent dit dat hij wegens misdrijf wordt veroordeeld, is de schuld niet aanmerkelijk dan gaat hij ook in geval van ernstige gevolgen vrijuit ${ }^{490}$ of kan hij worden veroordeeld voor overtreding van een toepasselijk veiligheidsvoorschrift. Dit betekent dat het vereiste van de aanmerkelijkheid der schuld uitdrukking is van de ernst van het verwijt dat iemand wordt gemaakt. ${ }^{491}$ Met name bij culpoze gevolgsdelicten staat daarbij de vraag centraal of iemand zo ernstig is tekortgeschoten in de op hem rustende zorgplicht dat hij strafrechtelijk aansprakelijk kan worden gesteld voor het veroorzaken van een - doorgaans - ernstig tot zeer ernstig gevolg. Een bevestigende beantwoording van die vraag vormt een zeer ingrijpend oordeel nu immers iemands opzet op dat gevolg niet was gericht maar hij toch in de vorm van veroordeling voor een misdrijf aansprakelijk wordt gesteld voor dood of zwaar lichamelijk letsel van een ander. Dat springt met name in het oog in gevallen waarin de schuld zich bevindt in de onderste regionen van de aanmerkelijkheid en iemand met een overigens smetteloze levensloop wordt belast met het oordeel dat zijn aanmerkelijke onachtzaamheid betekent dat

489 Bijv. HR 2I april 2009, LJN BH408o, HR 9 februari 20I0, LJN BK6943, HR 25 mei 20Io, LJN BL5625, HR 29 maart 20II, LJN BP3838, HR I4 juni 20II, LJN BQ3745.

490 Zie bijvoorbeeld HR 29 juni 20I0, LJN BL5630, NJ 2010, 674, m.nt. P.A.M. Mevis (kampvuur Castricum), besproken in 0 .

49I Zie HR 22 mei 20I2, LJN BU2or6, HR 3 juli 20I2, LJN BW4254 en HR I2 juni 20I2, LJN BW7948 t.a.v. roekeloosheid, zij het dat in het laatste arrest in afwijking van de onder 4.2 genoemde arresten niet wordt gesproken van (het ontbreken van voldoende) verwijt maar van 'ontbreken van voldoende verwijtbaarheid'. 
de dood van een ander aan zijn schuld te wijten is, temeer wanneer wordt bedacht dat een veelheid aan vergelijkbare aanmerkelijke onachtzaamheden, zoals hierna onder 5.II.I en 5.II.3 zal worden besproken, niet tot een zo ernstig gevolg leiden of helemaal zonder gevolg blijven.

\subsection{Heroriëntatie op de mate van schuld}

Zoals ik hiervoor onder I.2 beschreef, functioneert het culpoze gevolgsdelict in een andere maatschappelijke werkelijkheid dan ten tijde van de totstandkoming van het Wetboek van Strafrecht het geval was. Culpoze gevolgsdelicten doen zich thans in belangrijke mate voor in het wegverkeer, dat in de vorm waarin we het nu kennen ten tijde van de totstandkoming van het Wetboek van Strafrecht nog helemaal niet bestond. We zien het ook aan het voorbeeld dat Minister Modderman noemde toen hij zich uitliet over de bewuste schuld: (gas?)lichten in een feestzaal plaatsen bij licht ontvlambare stoffen met een brandspuit in de nabijheid opgesteld. ${ }^{492}$

$\mathrm{Nu}$ het zwaartepunt van de aansprakelijkstelling bij culpoze delicten ligt in de vraag of de vereiste mate van schuld aanwezig is, dwingt de nieuwe maatschappelijke werkelijkheid tot een invulling van het aanmerkelijke van de schuld die daarop is afgestemd.

In de wetenschap is de vraag naar de inhoud van het aanmerkelijke van de schuld nauwelijks onder ogen gezien. ${ }^{493}$ Daarmee staat in schril contrast dat bij hantering van culpoze delicten in de rechtspraak ondergrens en - in mindere mate - bovengrens van de culpa een bron vormen van onzekerheid en verschil in opvattingen. 494 Zoals ik onder 4.3 heb beschreven zijn uiteenlopende beslissingen daarvan het gevolg. ${ }^{495}$

De praktijk laat zien dat de beoordeling van het aanmerkelijke van de schuld een smeltkroes vormt van de meest uiteenlopende vragen, variërend van precisering van de ondergrens van de culpa in de rechtspraak via de factoren die bij het bepalen van de mate van schuld in aanmerking kunnen c.q. moeten worden genomen en - in verband daarmee - de praktische hantering van de ondergrens van de culpa, naar de rechtvaardiging van de bestraffing van culpoze delicten.

Hierna zullen diverse aspecten van het vereiste van het aanmerkelijke der schuld aan een onderzoek worden onderworpen. Het accent zal daarbij verschuiven van hoe het is naar hoe het moet zijn.

492 Smidt I, p. 8I.

493 Zie bijvoorbeeld het hiervoor aangehaalde proefschrift van Van Dijk. W. den Harder, Aanmerkelijk onvoorzichtig De ondergrens van de schuld in het verkeersstrafrecht, diss. Rotterdam 2006 , o.a. p. 235, gaat niet op zoek naar de inhoud van het aanmerkelijke van de schuld maar pleit ervoor deze invulling, zoals haars inziens ook in het privaatrecht geschiedt, te laten plaatsvinden door het oproepen van verweren door de strafrechter. Robroek, a.w., kent aan de inhoud van het aanmerkelijke van de schuld geen betekenis van belang toe.

494 Zie Robroek, a.w., p. II4, II5 over het verschil van opvattingen in de feitenrechtspraak.

495 Zo ook in Duitsland: Koch, a.w., p. 95, I67. 


\subsection{Boven- en ondergrens van de culpa volgens de wetgever}

Na de totstandkoming van het Wetboek van Strafrecht heeft de wetgever zich met de ondergrens van de aanmerkelijke schuld niet bemoeid. Kennelijk heeft de wetgever niet beoogd verandering te brengen in de ondergrens van de culpa. ${ }^{496}$ De aandacht van de wetgever is met name gericht geraakt op de maximumstraffen, gesteld op dood en zwaar lichamelijk letsel door schuld. Deze straffen - aanvankelijk negen en zes maanden gevangenisstraf - waren in de ogen van de wetgever te laag. ${ }^{497}$ In gevallen waarin aanmerkelijk onvoorzichtig gedrag tot dood of zwaar lichamelijk letsel van een ander leidde werden de ten hoogste op te leggen straffen in $2006^{498}$ verhoogd tot twee respectievelijk één jaar gevangenisstraf. Was sprake van roekeloosheid dan werden deze straffen nog weer verdubbeld (zie thans art. 307 en 308 $\mathrm{Sr}^{499}$ ). Reeds enige jaren eerder, ${ }^{500}$ in 1998 , had de wetgever de maximumstraf op dood en zwaar lichamelijk letsel in het verkeer (art. 6 WVW I994) verhoogd. Daarbij was aan de bestaande strafverzwarende omstandigheid van rijden onder invloed de ernstige overschrijding van de maximumsnelheid als nieuwe strafverzwarende omstandigheid toegevoegd. In 2006 werden de straffen op dood en zwaar lichamelijk letsel door schuld verder verhoogd en de strafverzwarende omstandigheden uitgebreid met roekeloosheid, bumperkleven, geen voorrang verlenen en gevaarlijk inhalen..$^{\text {or }}$

496 In Kamerstukken II, 200I-2002, 28 484, nr. 3, p. 2 en 7, spreekt de wetgever bij een voorstel tot verhoging van de maximumstraf op culpoze delicten van 'aanmerkelijk onvoorzichtig gedrag'. Zie voorts D.H. de Jong, Onbewuste schuld. Een probleem bij de kwalificatie of bij de straftoemeting? (afscheidscollege), Deventer: Kluwer 2007, p. 8.

497 Kamerstukken II, 200I-2002, 28 484, nr. 3, p. 2. Zie over het wetsontwerp uitgebreid D.H. de Jong, M. Kessler, M. Otte en H.D. Wolswijk, Verhoging van strafmaximum op culpose misdrijven D\&D 2003, p. 258-28o en H.J.A. Ham, Gewijzigde strafmaxima voor het culpose verkeersmisdrijf van artikel 6 WVW I994, Verkeersrecht 2004, p. 68-72.

498 Wet van 22 december 2005, Stb. 2006, II, in werking getreden I februari 2006.

499 Deze bepalingen luiden thans:

Art. $307 \mathrm{Sr}$ :

I. Hij aan wiens schuld de dood van een ander te wijten is, wordt gestraft met gevangenisstraf van ten hoogste twee jaren of geldboete van de vierde categorie.

2. Indien de schuld bestaat in roekeloosheid, wordt hij gestraft met gevangenisstraf van ten hoogste vier jaren of geldboete van de vierde categorie.

Art. $308 \mathrm{Sr}$ :

I. Hij aan wiens schuld te wijten is dat een ander zwaar lichamelijk letsel bekomt of zodanig lichamelijk letsel dat daaruit tijdelijke ziekte of verhindering in de uitoefening van zijn ambtsof beroepsbezigheden ontstaat, wordt gestraft met gevangenisstraf van ten hoogste een jaar of geldboete van de vierde categorie.

2. Indien de schuld bestaat in roekeloosheid, wordt hij gestraft met gevangenisstraf van ten hoogste twee jaren of geldboete van de vierde categorie.

500 Wet van 24 juni 1998 , Stb. 375.

50I Art. 175 WVWig94 luidt thans:

I. Overtreding van artikel 6 wordt gestraft met:

a. gevangenisstraf van ten hoogste drie jaren of geldboete van de vierde categorie, indien het een ongeval betreft waardoor een ander wordt gedood;

b. gevangenisstraf van ten hoogste een jaar en zes maanden of geldboete van de vierde categorie, indien het een ongeval betreft waardoor een ander lichamelijk letsel wordt toegebracht. 2. Indien de schuld bestaat in roekeloosheid, wordt overtreding van artikel 6 gestraft met: 
De wetgever ziet roekeloosheid dus als zwaarste vorm van culpa. Roekeloosheid wordt door de wetgever omschreven als 'zeer onvoorzichtig gedrag waarbij welbewust en met ernstige gevolgen onaanvaardbare risico's zijn genomen', als 'een zeer ernstig gebrek aan zorgvuldigheid', 'binnen de grenzen van het culpoze delict (...) het zwaarste verwijt dat iemand kan worden gemaakt', als 'welbewust onaanvaardbare risico's nemen', of als 'bewustheid van het risico van ernstige gevolgen, waarbij op zeer lichtzinnige wijze ervan wordt uitgegaan dat deze risico's zich niet zullen realiseren'. ${ }^{502}$

\subsection{De ondergrens van de culpa in de rechtspraak}

Zoals de Hoge Raad tot uitdrukking heeft gebracht hangt het af van de manier waarop de schuld in de tenlastelegging nader is geconcretiseerd, en voorts van het geheel van de gedragingen van de verdachte, de aard en de ernst daarvan en de overige omstandigheden van het geval of sprake is van culpa, van aanmerkelijke schuld. Daarom is niet eenvoudig uit de rechtspraak te kennen wanneer een onvoorzichtigheid of onoplettendheid aanmerkelijke schuld oplevert, zeker niet voor zover een onoplettendheid of onvoorzichtigheid plaatsvindt in een (min of meer) unieke context, zoals 'leestafelzooien'503 of onzorgvuldigheid bij de constructie van een steiger in een ketel van een elektriciteitscentrale. ${ }^{504}$ Wel kan ten aanzien van culpoze gevolgsdelicten worden gezegd dat - zie 4.5 en 4.6 - de enkele momentane onoplettendheid in beginsel geen culpa lijkt te kunnen opleveren.

De rechtspraak met betrekking tot culpa in het verkeer biedt door het grote aantal uitspraken in overeenkomstige, door wettelijke voorschriften geregelde situaties meer houvast. Onderzoek van de rechtspraak tot I980 liet zien dat in de rechtspraak van de Hoge Raad, hoe ook gebonden aan de concrete omstandigheden van het geval, een aantal typen gevallen zijn te onderscheiden waarin globaal genomen van aanmerkelijke schuld kan worden gesproken. ${ }^{505}$ Deze gevallen zijn:

a. gebrek aan voorzorg;

b. bewust nemen van risico;

a. gevangenisstraf van ten hoogste zes jaren of geldboete van de vijfde categorie, indien het een ongeval betreft waardoor een ander wordt gedood;

b. gevangenisstraf van ten hoogste drie jaren of geldboete van de vierde categorie, indien het een ongeval betreft waardoor een ander lichamelijk letsel wordt toegebracht.

3. Indien de schuldige verkeerde in de toestand, bedoeld in artikel 8, eerste, tweede, derde of vierde lid, dan wel na het feit niet heeft voldaan aan een bevel, gegeven krachtens artikel I6 3 , tweede, zesde, achtste of negende lid, of indien het feit is veroorzaakt of mede is veroorzaakt doordat hij een krachtens deze wet vastgestelde maximumsnelheid in ernstige mate heeft overschreden, dan wel zeer dicht achter een ander voertuig is gaan rijden, geen voorrang heeft verleend of gevaarlijk heeft ingehaald kunnen de in het eerste en tweede lid bepaalde gevangenisstraffen met de helft worden verhoogd.

502 Kamerstukken II 200I-2002, 28 484, nr. 3, p. I2. Zie hierover Robroek p. 59, 60.

503 HR 3I oktober 2006, LJN AX9178, NJ 2007, 79, m.nt. N. Keijzer.

504 .HR I5 juni 20I0, LJN BL7690 (Amercentrale).

505 Gevaar en schuld op de weg, p. I22 e.v. 
c. onvoorzichtigheid van een bestuurder die onvoldoende tot behoorlijk besturen in staat moet worden geacht; en

d. maken van een verkeersfout onder omstandigheden die gunstig zijn om die fout te voorkomen, zoals goed uitzicht, bekendheid ter plaatse e.d.

Deze categorieën gevallen zijn nog steeds in de huidige rechtspraak te onderkennen. ${ }^{506}$ Van gebrek aan voorzorg die de culpa aanmerkelijk maakte, was bijvoorbeeld sprake in het geval van de voorrangsplichtige bestuurder van een tractor die een op de voorrangsweg rijdende personenauto niet had gezien terwijl hij zijn snelheid bij nadering van de kruising niet had aangepast aan de mogelijkheid dat hij aan van links komend verkeer voorrang moest geven. ${ }^{507}$

Met betrekking tot het bewust nemen van risico moet worden opgemerkt dat - zoals hierna onder 5.10.3 nog aan de orde komt - niet ieder nemen van risico ongeoorloofd is. Het komt aan op het nemen van ongeoorloofd risico.

Aan het bewijs van de aanmerkelijke onvoorzichtigheid van de bestuurder die onder invloed verkeert, de onder c genoemde categorie, lijkt de Hoge Raad geen hoge eisen te stellen. Maakt hij enige fout dan lijkt daarmee zijn aanmerkelijke schuld aan een daaruit voortvloeiend ongeval gegeven te zijn. Ik wijs op de in afwijking van de conclusies gewezen HR 29 april 2008, LJN BDo70958 en HR 22 november 20II, LJN BR3005:509 niet tijdig remmen voor een bij duisternis midden op straat zittende persoon c.q. voor een op een verlichte straat overstekende voetganger zonder dat - in afwijking van de conclusies van het parket - veel aandacht wordt geven aan de vraag of de aangereden persoon voor de bestuurder tijdig waarneembaar was.

Of de onder d genoemde categorie nog een juiste beschrijving van de rechtspraak vormt, valt te betwijfelen. Zoals we intussen immers weten - zie 4.5 - levert het maken van een verkeersfout onder omstandigheden die gunstig zijn om die fout te voorkomen geen culpa op in die gevallen waarin sprake is van een enkele momentane onoplettendheid. De onder d genoemde categorie moet daarom worden aangevuld met de beperking dat gevallen van momentane onoplettendheid daarop een uitzondering vormen.

\subsection{De bovengrens van de culpa in de rechtspraak}

Over het snijvlak van opzet en culpa ten aanzien van een gevolg merkt de Hoge Raad in het eerste HIV-arrest ${ }^{\text {50 }}$ het volgende op:

'Voorwaardelijk opzet op een bepaald gevolg - zoals hier de dood - is aanwezig indien de verdachte zich willens en wetens heeft blootgesteld aan de aanmerkelijke kans dat dat gevolg zal intreden.

(...).

506 Zie ook de bespreking van de rechtspraak in de conclusie bij HR I juni 2004, LJN AO5822, NJ 2005, 252, m.nt. G. Knigge, nrs. I2-I5.

507 HR 2I april 2009, LJN BG9I42, NJ 2009, 209.

508 NJ 2008, 439, m.nt. N. Keijzer onder nr. 442.

509 NJ 20I2, I75, m.nt. B.F. Keulen.

5IO HR 25 maart 2003, LJN AE9049, NJ 2003, 552, m.nt. YB. 
Voor de vaststelling dat de verdachte zich willens en wetens heeft blootgesteld aan zulk een kans is niet alleen vereist dat de verdachte wetenschap heeft van de aanmerkelijke kans dat het gevolg zal intreden, maar ook dat hij die kans ten tijde van de gedraging bewust heeft aanvaard (op de koop toe heeft genomen). Uit de enkele omstandigheid dat die wetenschap bij de verdachte aanwezig is dan wel bij hem moet worden verondersteld, kan niet zonder meer volgen dat hij de aanmerkelijke kans op het gevolg ook bewust heeft aanvaard, omdat in geval van die wetenschap ook sprake kan zijn van bewuste schuld.

Van degene die weet heeft van de aanmerkelijke kans op het gevolg, maar die naar het oordeel van de rechter ervan is uitgegaan dat het gevolg niet zal intreden, kan wel worden gezegd dat hij met (grove) onachtzaamheid heeft gehandeld maar niet dat zijn opzet in voorwaardelijke vorm op dat gevolg gericht is geweest.'

Wie wetenschap heeft van de aanmerkelijke kans op een gevolg heeft pas opzet op dat gevolg wanneer hij die kans bewust heeft aanvaard. Is hij ervan uitgegaan dat dit gevolg niet zal intreden dan heeft hij met (grove) onachtzaamheid gehandeld..$^{\text {II }}$ Het hoeft geen betoog dat hier bewijsproblemen op de loer liggen. Laat de verdachte zich uit over zijn visie op eventuele gevolgen van zijn gedrag - de dronken bestuurder die aan het einde van een uitgaansavond naar zijn zeggen koste wat kost aan de politie wilde ontsnappen en daarbij met zijn auto meerdere fietsers doodreed, ${ }^{512}$ de spookrijder die zijn gedrag 'kicken' vond ${ }^{513}$ - dan valt het bewijs van het voorwaardelijk opzet eenvoudig te leveren en komt culpa niet aan de orde. Dat is anders wanneer de verdachte zwijgt en ook getuigen geen inzicht bieden in hetgeen in de verdachte is omgegaan. Dan zal het, zoals de Hoge Raad het uitdrukt, afhangen van de omstandigheden van het geval of van voorwaardelijk opzet sprake is:

'Daarbij zijn de aard van de gedraging en de omstandigheden waaronder deze is verricht, van belang. Bepaalde gedragingen kunnen naar hun uiterlijke verschijningsvorm worden aangemerkt als zo zeer gericht op een bepaald gevolg dat het - behoudens contra-indicaties - niet anders kan zijn dan dat de verdachte de aanmerkelijke kans op het desbetreffende gevolg heeft aanvaard.'

Van dat laatste was naar het oordeel van de Hoge Raad geen sprake in het geval van de bestuurder van de Porsche, die werd vervolgd ter zake van doodslag omdat hij bij een inhaalmanoeuvre op een tweebaansweg op de linker weghelft frontaal op een tegenligger was gebotst met als gevolg dat vijf personen - één inzittende van de Porsche en vier inzittenden van de tegemoetkomende auto - om het leven

5 II Onder omstandigheden kan het bewust aanvaarden van een aanmerkelijke kans ook zijn gelegen in het achterwege laten van toezicht of onderzoek dat van de verdachte in de omstandigheden van het geval mocht worden verwacht. Zie HR I7 januari 20II, LJN BU42II (voorwaardelijk opzet op valse identiteitspapieren in administratie door iedere voorzorgsmaatregel achterwege te laten) en HR 5 juli 20II, LJN BQ6r40, NJ 20II, 327 (voorwaardelijk opzet op invoer cocaïne door achterwege laten van ieder onderzoek naar inhoud koffer).

5 I2 HR 23 januari 200I, NJ 200I, 327 (Enkhuizen).

5I3 HR 5 december 2006, LJN AZI668, NJ 2006, 663. 
kwamen..$^{\text {I4 }}$ De bestuurder had in de drie uur voorafgaande aan het ongeval in drie cafés 'drie of vier glazen bier', 'een paar glazen bier' en 'een paar pilsjes' gedronken. Uit verklaringen van getuigen bleek dat hij kort voor het ongeval twee keer door rood licht was gereden, dat hij diverse voor hem rijdende auto's had ingehaald door deze met een korte beweging voorbij te rijden en daarna, gelet op de tegenliggers, nog net op tijd weer naar rechts te zwenken, dat hij kort voor de aanrijding twee- à driemaal had geprobeerd een voorliggende auto in te halen, daartoe vrij abrupt naar links en meteen weer naar rechts gaand, waarna hij tijdens de vierde inhaalpoging frontaal met de door hem bestuurde Porsche tegen een uit de tegenovergestelde richting komende auto was gebotst. Anders dan het hof achtte de Hoge Raad niet zonder meer bewezen dat verdachte voorwaardelijk opzet had gehad op de dood van de slachtoffers. Naar ervaringsregels achtte de Hoge Raad niet waarschijnlijk dat verdachte de aanmerkelijke kans op de koop toe zou hebben genomen dat hij frontaal op een tegemoetkomende auto zou botsen omdat hij de aanmerkelijke kans liep daardoor zelf ook het leven te verliezen. Volgens de Hoge Raad wees het feit dat de verdachte meermalen - kennelijk om een botsing te vermijden - een ingezette inhaalmanoeuvre had afgebroken vooraleer de in de bewezenverklaring bedoelde fatale inhaalmanoeuvre uit te voeren erop dat althans in de voorstelling en naar de verwachting van de verdachte zijn manoeuvre niet tot een botsing zou leiden. ${ }^{515}$

Tegen de uitspraak van de Hoge Raad rezen in de literatuur nogal wat bedenkingen, ${ }^{516}$ onder meer omdat deze adequate bestraffing van wegpiraten onmogelijk zou maken ${ }^{57}$ en er werd gevreesd dat in al die gevallen waarin de verdachte het gevaar liep door zijn handelingen ook zelf om het leven te komen of zwaar gewond te raken bewijs van het opzet onmogelijk zou zijn. Die laatste vrees bleek ongegrond. Ik wijs op het hiervoor genoemde geval van de spookrijder ${ }^{518}$ alsmede op het geval van veroordeling voor doodslag van de bezoeker van de kermis van St. Michielsgestel, die in kennelijke staat van dronkenschap met zijn terreinwagen veel sneller rijdend dan ter plaatse was toegestaan een groepje fietsers aanreed en met gedoofde lichten van de plaats van het ongeval vluchtte..$^{\text {59 }}$ In deze zaak abstraheerde de Hoge Raad van het oordeel van het hof dat niet gezegd kan worden dat verdachte ook de aanmerkelijke kans dat hij het leven zou laten op de koop toe

5 I4 HR I5 oktober I996, NJ I997, I99, m.nt. 'tH.

5 I5 Nerwijzing werd de verdachte vrijgesproken van doodslag: Hof Arnhem Io maart I997, VR I997, I6r m.nt. A. Dijkstra bij VR I997, I60.

5 I6 Zie onder meer J. de Hullu, Materieel strafrecht, Deventer: Kluwer 20I2, vijfde druk, p. 240 en 24I, die opmerkt dat overweging 5.4 erg gedetailleerd psychologiserend is, zodat hoge drempels voor doodslag in het verkeer worden opgeworpen. Dat past in zijn ogen niet erg bij de algemene lijnen in de rechtspraak over opzet. Ook Otte, Opzet en schuld in het verkeer, Deventer 200I, p. 9-II, is kritisch over het arrest. Instemmend is Van Dijk, Strafrechtelijke aansprakelijkheid heroverwogen Over opzet, schuld, schulduitsluitingsgronden en straf, (diss. Groningen 2008), p.292 e.v., die de uitspraak in het Porsche-arrest plaatst tegen de aansprekende achtergrond van het besef 'dat het - bijzondere omstandigheden daargelaten - gewoonweg niet voor de hand [ligt] dat een verkeersdeelnemer dodingsopzet heeft.' Daarom, aldus Van Dijk, dient het opzetbewijs in verkeerszaken altijd tegen de achtergrond van de onbewustheidsassumptie plaats te vinden (p. 295).

517 Noot A. Dijkstra bij HR I5 oktober I996, VR I997, I6o (NJ I997, I99, m.nt. 'tH) (Porsche).

5 I8 HR 5 december 2006, LJN AZI668, NJ 2006, 663.

5I9 HR I7 februari 2004, NJ 2004, 323 (kermis St. Michielsgestel). 
heeft genomen omdat de overige gronden die het hof aan het bewijs van het opzet ten grondslag had gelegd - kort gezegd dat het verdachte om het even was of hij met zijn zware terreinwagen een zwakke verkeersdeelnemer als een fietser zou aanrijden - het bewijs van het opzet zelfstandig konden dragen..$^{520}$

Vermoedelijk kan wel worden gezegd dat op contra-indicaties voor het op de koop toe nemen van de aanmerkelijke kans op een ernstig gevolg daadwerkelijk acht moet worden geslagen en doorgaans moet worden uitgelegd waarom deze niet aan het aannemen van voorwaardelijk opzet in de weg staan..$^{52}$ Dat deed het hof in de zaak die ten grondslag lag aan HR Io februari 2009, LJN BG663I. De verdachte - autoberger - was gewaarschuwd vanwege zijn alcoholgebruik niet te gaan rijden, deed dat wel en reed binnen de bebouwde kom met een snelheid van meer dan $120 \mathrm{~km} / \mathrm{u}$ door rood licht en botste daardoor op een ander voertuig met de dood van twee inzittenden van dat voertuig als gevolg. Ter motivering van het bewezenverklaarde opzet op levensberoving overwoog het hof onder meer dat verdachte kennelijk zelfs bereid was zichzelf en zijn vriendin aan dodelijk letsel bloot te stellen.

Voorts wijs ik er hier nog op dat aan de voor voorwaardelijk opzet vereiste aanmerkelijkheid van de kans niet te licht mag worden getild. De Hoge Raad heeft niet alleen zijn formulering aangescherpt - aanvankelijk werd gesproken van een geenszins als denkbeeldig te verwaarlozen kans ${ }^{522}$, thans (ook in het Porsche-arrest) van een aanmerkelijke kans ${ }^{523}$ - maar wil, zo blijkt uit de zogenaamde HIV-arresten, ${ }^{524}$ ook daadwerkelijk meer zien dan een niet te verwaarlozen kans. En die kans mag niet gerelateerd worden aan de ernst van het gevolg in die zin dat naarmate het potentiële gevolg van een handeling ernstiger is ook eerder van een aanmerkelijke kans zou kunnen worden gesproken. 'Het zal in alle gevallen moeten gaan om een kans die naar algemene ervaringsregelen aanmerkelijk is te achten. ${ }^{525}$ Dit betekent dat het op de koop toenemen van een kleine kans op een ernstig gevolg geen (voorwaardelijk) opzet kan opleveren.

In de tweede alinea van deze paragraaf heb ik gesteld dat met handelen in de bewustheid van de aanmerkelijke kans op het gevolg van die handeling de culpa is gegeven. De Hoge Raad lijkt dit door te spreken van '(grove) onachtzaamheid' in plaats van 'minstgenomen een min of meer grove of aanmerkelijke onvoorzichtigheid of onachtzaamheid'526 zoals de standaardformulering voor de culpa luidt,

520 Zie ook HR 29 september 2009, LJN BI4736, NJ 20I0, II7, m.nt. N. Keijzer.

52I Zoals valt op te maken uit HR 25 maart 2003, LJN AE9049, NJ 2003, 552, m.nt. YB, rov. 3.6, slot.

522 HR 9 november I954, NJ I955, 55 (Cicero), HR 2I februari I978, NJ I978, 384; ook werd wel gesproken van de geenszins geringe kans (HR 26 februari 1957, NJ 1957, 385) of van de geenszins te verwaarlozen kans (HR 2I juni ig66, NJ I966, 409, m.nt. W.P.).

523 Zo in HR 3 januari I978, NJ I978, 627, HR 9 mei I995, NJ I995, 50I, het hiervoor besproken HR I5 oktober 1996, NJ 1997, I99, m.nt. 'tH (Porsche), HR Io oktober 2000, NJ 2001, 4, m.nt. Y. Buruma, HR 23 januari 200I, LJN ZD2257, NJ 200I, 24I.

524 HR 25 maart 2003, LJN AE9049, NJ 2003, 552, m.nt. YB, HR 24 juni 2003, LJN AF8058, NJ 2003, 555, HR 28 januari 2005, LJN ARI86o, NJ 2005, I54, m.nt. D.H. de Jong, HR 20 februari 2007, LJN AY9659, NJ 2007, 313, m.nt. Y. Buruma. De arresten hadden steeds betrekking op de vraag of iemand die in de wetenschap dat hij met HIV is geïnfecteerd met een ander seksuele gemeenschap heeft, opzet heeft op het toebrengen van dood of zwaar lichamelijk letsel van die ander.

525 HR 25 maart 2003, LJN AE9049, NJ 2003, 552, m.nt. YB, rov. 3.6.

526 Zie reeds het hiervoor onder o besproken HR I4 november I887, W 5509. 
enigszins in het midden te laten. Doorgaans echter zal iemand die handelt in de bewustheid van een aanmerkelijke kans op een ernstig gevolg als dood of zwaar lichamelijk letsel heel wat hebben uit te leggen om duidelijk te maken waarom hij niet roekeloos althans hoogst onvoorzichtig is geweest als het gevreesde gevolg intreedt.

Overeenkomstig de wet (zie 5.4) wordt roekeloosheid ook in de rechtspraak als zwaarste vorm van culpa gezien. ${ }^{527}$ Aan het bewijs daarvan stelt de Hoge Raad mede met het oog op het strafverhogende effect van dit bestanddeel 'bepaaldelijk eisen' terwijl de rechter in voorkomende gevallen aan het bewijs van de roekeloosheid in zijn motivering van de bewezenverklaring nadere aandacht dient te geven. ${ }^{228}$ Aan die eisen was niet voldaan in een geval waarin de chauffeur van een taxi zonder ontheffing met veel te hoge snelheid over een trambaan had gereden en daarbij een voetganger had geschept met zwaar lichamelijk letsel van die voetganger als gevolg:

'De door het Hof genoemde omstandigheden dat de verdachte in de hoedanigheid van beroeps(taxi)chauffeur's nachts op een nat wegdek met onbelemmerd zicht met een veel te hoge snelheid en zonder ontheffing heeft gereden op de trambaan, dat de verdachte op de hoogte was van de daar geldende lagere maximumsnelheid en het gevaar van de langere remweg op de tramrails, en voorts dat de verdachte de voetganger heeft gezien maar heeft gedacht dat deze een andere kant op zou gaan en vervolgens die voetganger - terwijl deze de rijbaan reeds was overgestoken ter hoogte van de voetgangersoversteekplaats en doende was de trambaan over te steken - heeft aangereden, zouden toereikend kunnen zijn voor het oordeel dat de verdachte - zoals hem onder primair eveneens is tenlastegelegd - "zeer, althans aanmerkelijk onoplettend, onvoorzichtig, onachtzaam" heeft gereden, maar zij zijn niet zonder meer toereikend voor het oordeel van het Hof dat de verdachte "roekeloos" in de zin van art. 6 in verbinding met art. I75 WVW 1994 heeft gereden. 529

Ten aanzien van dood of zwaar lichamelijk letsel door schuld in de vorm van roekeloosheid in het verkeer (art. 6 jo. I75 WVW 1994) wijst de Hoge Raad erop dat de door hem gestelde eisen ook gelden in de gevallen waarin de roekeloosheid in de kern bestaat uit de in art. 175, derde lid, WVW 1994 omschreven gedragingen: rijden onder invloed, ernstige overschrijding van de maximumsnelheid, zeer dicht achter een ander gaan rijden, geen voorrang verlenen en gevaarlijk inhalen. Deze gedragingen vormen immers op zichzelf al een grond voor een verdere verhoging van het ingevolge het tweede lid van dat artikel voor roekeloosheid geldende strafmaximum.

527 HR 22 mei 20I2, LJN BU20I6, HR 3 juli 20I2, LJN BW4254 en HR I2 juni 20I2, LJN BW7948.

528 HR 22 mei 20I2, LJN BU2OI6, HR I2 juni 20I2, LJN BW7948 en HR 3 juli 20I2, LJN BW4254.

529 HR 3 juli 20I2, LJN BW4254. 


\subsection{Strafmaat}

Openbaar Ministerie ${ }^{530}$ en rechterlijke macht ${ }^{53^{1}}$ hanteren bij de bepaling van de te vorderen c.q. op te leggen straf voor dood of zwaar lichamelijk letsel door schuld in het verkeer (art. 6 WVW 1994) drie categorieën gevallen (in afnemende ernst): wegpiraterij/roekeloos rijden, grove verkeersfout, aanmerkelijke verkeersfout. Naarmate de ernst van de fout en/of het gevolg groter is, worden de te vorderen c.q. op te leggen straffen zwaarder. Alcoholgebruik vormt een strafverzwarende omstandigheid. De te vorderen c.q. op te leggen straffen lopen van een geldboete van $€$ I200 c.q. Iooo en een ontzegging van de rijbevoegdheid voor de duur van drie maanden tot een gevangenisstraf van vier jaar en een ontzegging van de rijbevoegdheid voor de duur van vijf jaar. Enige omschrijving van de gehanteerde categorieën ontbreekt. Een uitzondering daarop vormt de Aanwijzing verkeersongevallen van het Openbaar Ministerie waarin voor de beschrijving van roekeloosheid wordt aangesloten bij de hiervoor onder 5.4 aangehaalde beschrijving in de parlementaire geschiedenis.

\subsection{Waarop heeft het aanmerkelijke van de schuld betrekking?}

De vraag rijst waarop het aanmerkelijke van de schuld betrekking heeft: op de onachtzaamheid of op het uit die onachtzaamheid voorvloeiende uiterlijk onvoorzichtige gedrag? Het hiervoor onder 4.5 besproken HR 29 april 2008, LJN BDo544 (Geervliet) ${ }^{532}$ laat zien dat het aanmerkelijke betrekking heeft op de onachtzaamheid en niet op de uiterlijke onvoorzichtigheid van het gedrag. Daar was immers sprake van naar uiterlijke maatstaven gerekend bijzonder onvoorzichtig gedrag-als voorrangsplichtige zo dicht voor een motorrijdster de voorrangsweg oprijden dat deze een zware botsing niet kon vermijden - maar werd het bewijs van 'aanmerkelijk onoplettend en met aanmerkelijke verwaarlozing van de te dezen geboden zorgvuldigheid' niet geleverd geacht. Zou het aanmerkelijke op het uiterlijk onvoorzichtige van het gedrag betrekking hebben ${ }^{53}$ dan zou - zoals het voorgaande laat zien - er ook aan voorbij worden gegaan dat niet reeds uit de ernst van de gevolgen van verkeersgedrag dat in strijd is met één of meer wettelijke gedragsregels in het verkeer, kan worden afgeleid dat sprake is van aanmerkelijke schuld (HR I juni 2004, LJN AO5822 (Winssen)). 534

Het ten onrechte betrekken van het aanmerkelijke op het uiterlijk onvoorzichtige van het gedrag is mogelijk een belangrijke oorzaak van de hiervoor in 4.3 genoemde rechterlijke uitspraken die erop neerkomen dat met de enkele verkeersovertreding de culpa gegeven is. In de grond van de zaak ligt dat misverstand ook besloten in art. I76 WVW 1994 voor zover daarin aan louter uiterlijk onjuist verkeersgedrag

530 Richtlijn voor strafvordering verkeersongevallen van I januari 20I2, Stcrt. 20II, nr. 22817.

53I Oriëntatiepunten straftoemeting van het LOVS, 3I oktober 2008.

532 NJ 2008, 440 met noot N. Keijzer onder NJ 2008, 442.

533 Zo de wetgever ter motivering van de verhoging van de maximumstraffen op culpoze delicten (Kamerstukken II, 200I-2002, 28 484, nr. 3, p. 2), maar daarbij lijkt de wetgever zich het in de tekst aangesneden punt niet te hebben gerealiseerd.

534 NJ 2005, 252, m.nt. G. Knigge. 
- veel te snel rijden, geen voorrang verlenen, gevaarlijk inhalen - strafverhoging wordt verbonden. Ik wijs op het hiervoor onder 4.5 besproken HR 29 april 2008, LJN BD0544 (Geervliet)535 waarin wel sprake was van (de strafverhogende omstandigheid van) geen voorrang verlenen maar de gebezigde bewijsmiddelen voor het bewijs van de culpa onvoldoende basis boden.

\subsection{Bewuste en onbewuste schuld}

In de literatuur pleegt de culpa te worden onderscheiden in bewuste schuld: ongeoorloofde risico's nemen in de (achteraf onjuist gebleken) veronderstelling dat deze zich niet zullen realiseren, en onbewuste schuld: niet zien of niet weten waar men wel had behoren te zien of te weten. ${ }^{53^{6}}$ Zoals de parlementaire geschiedenis en de rechtspraak laten zien is de aanmerkelijke schuld niet beperkt tot de bewuste schuld. Dat hoeft ook geen verbazing te wekken. 'Voor wat betreft de strafwaardigheid zal de onbewuste culpa niet zelden ernstiger zijn dan de bewuste culpa, want bij bewuste culpa heeft de dader zich tenminste nog om de gevolgen bekommerd al heeft hij deze dan ook lichtvaardig onderschat.', aldus Remmelink. ${ }^{537}$ Voor de bepaling van de mate van schuld is het onderscheid tussen bewuste en onbewuste schuld dan ook niet van substantiële betekenis..$^{53}$

\section{I0 Factoren die bij de beoordeling van de mate van schuld in aanmerking komen}

\subsubsection{Inleiding}

Of sprake is van een min of meer grove of aanmerkelijke schuld hangt af van het geheel van de gedragingen van de verdachte, de aard en de ernst daarvan en de overige omstandigheden van het geval. ${ }^{539}$ Dit is door de Hoge Raad tot uitdrukking gebracht voor enkele culpoze gevolgsdelicten (art. 6 WVW I994, art. 308 Sr), maar er is geen reden daarover voor andere culpoze gevolgsdelicten anders te oordelen..$^{5{ }^{\circ}}$ Ook voor culpa ten aanzien van een bepaalde omstandigheid - van misdrijf afkomstig zijn bij schuldheling (art. 4I7bis Sr) bijvoorbeeld - zal gelden dat het antwoord

535 NJ 2008, 440 met noot N. Keijzer onder NJ 2008, 442.

536 Noyon-Langemeijer-Remmelink, Het Wetboek van Strafrecht, Culpa, aant. 6 (suppl. I54, september 20II).

537 Noyon-Langemeijer-Remmelink, Het Wetboek van Strafrecht, Culpa, aant. 6 (suppl. I54. september 20II). Eerder al J. Remmelink, Hazewinkel-Suringa's Inleiding tot de studie van het Nederlandse Strafrecht, Arnhem: Gouda Quint 1996, vijftiende druk, p. 234. Zo ook Koch, a.w., p. 246. Anders Minister Modderman, Smidt I, p. 8I

538 Dit wordt bevestigd door het onderzoek van Robroek naar rechtspraak in feitelijke aanleg over culpa. Zie ook Koch, a.w., p. 245.

539 HR I juni 2004, LJN AO5822, NJ 2005, 252, m.nt. G. Knigge (Winssen) ten aanzien van schuld in het verkeer (art. 6 WVWr994), HR 29 juni 20I0, LJN BL5630, NJ 2010, 674, m.nt. P.A.M. Mevis (kampvuur Castricum) ten aanzien van art. $308 \mathrm{Sr}$.

540 Zo HR I2 juni 20I2, LJN BW7948 (landmachtdemonstratie) voor art. I30 WMSr. 
op de vraag naar de culpa afhankelijk is van de concrete omstandigheden van het geval.

Het spreekt voor zichzelf dat in geval van strafvervolging voor de rechter uitgangspunt dient te zijn hoe de culpa is tenlastegelegd: in welke graad, met betrekking waarop. Hoe ernstiger de tenlastegelegde culpa, des te zwaarder de eisen die aan het bewijs van de aanmerkelijke schuld worden gesteld..$^{54}$

Minder vanzelfsprekend is welke omstandigheden in het culpa-oordeel moeten worden betrokken, welke niet.

\subsubsection{Factoren van belang voor het oordeel over de aanmerkelijkheid van de schuld bij culpoze gevolgsdelicten}

In de kern van de zaak gaat het - gegeven een onachtzaamheid - bij de vraag naar de factoren die van belang zijn voor het 'aanmerkelijke schuld'-oordeel in belangrijke mate om de vraag of er voor rekening van de verdachte komende feiten of gedragingen zijn die afdoen aan de vermijdbaarheid van de onachtzaamheid dan wel die erop wijzen dat ernaar is gestreefd die onachtzaamheid te vermijden. Veiligheidsvoorschriften, feiten van algemene bekendheid en algemene ervaringsregels vormen hierbij een kader voor de oordeelsvorming.

Culpa wordt in de tenlastelegging veelal 'ingevuld' met begrippen als 'onachtzaamheid', 'onoplettendheid' en/of 'onvoorzichtigheid'. Onachtzaamheid wordt doorgaans gehanteerd als verzamelbegrip voor onoplettendheid en onvoorzichtigheid. Onoplettendheid duidt op die gevallen waarin de verdachte niet heeft gezien waar hij had moeten zien, onvoorzichtigheid op gevallen waarin de verdachte niet heeft voorzien terwijl hij wel had moeten voorzien. Vaak zijn beide begrippen niet goed te scheiden. Wie als voorrangsplichtige een voorrangsgerechtigde geheel niet ziet, treft het verwijt dat hij niet heeft gezien waar hij had moeten zien en was dus onoplettend, het verwijt aan de voorrangsplichtige die de voorrangsgerechtigde wel ziet maar diens snelheid verkeerd inschat en de voorrangsweg oprijdt hoewel dat niet meer veilig kon geschieden, bestaat in behoren te voorzien waar men niet heeft voorzien, dus in niet voorzichtig zijn. Maar in het laatste geval kan ook worden gezegd dat de voorrangsplichtige niet goed heeft opgelet, immers de snelheid van de voorrangsgerechtigde verkeerd heeft ingeschat. In tenlasteleggingen figureren onoplettendheid en onvoorzichtigheid daarom veelal naast elkaar, liefst aangevuld met het verzamelbegrip 'onachtzaamheid'.

Zien we waardoor gevallen van aanmerkelijke schuld gekenmerkt worden - zie 5.5 - dan springt in het oog dat de overgang van schuld naar aanmerkelijke schuld veelal wordt gekenmerkt door gebrek aan voorzorg gericht op het voorkomen van fatale fouten. Van belang is dus het 'voortraject' van de onoplettendheid of onvoorzichtigheid. Zijn voorzorgen genomen om de kans op onoplettendheid of onvoorzichtigheid te verminderen of juist niet: is de snelheid zover teruggebracht dat behoorlijk kon worden uitgekeken, is het opschrift op het flesje gelezen alvorens

54I Zie de in 4.2 genoemde arresten alsmede HR 22 mei 20I2, LJN BU2or6 en HR 3 juli 20I2, LJN BW4254 (roekeloosheid). 
de inhoud op een smeulend vuur te gieten? Dat gebrek aan voorzorg kan ook hierin bestaan dat een gedraging, gelet op de daaraan verbonden gevaren, zonder meer achterwege had moeten worden gelaten. Van belang daarbij is hoe noodzakelijk die gedraging voor het normaal functioneren van het maatschappelijk verkeer is. Voor normale deelname aan het wegverkeer is noodzakelijk dat men links en rechts afslaat en een voorrangsweg oprijdt ook al zijn dat gedragingen die het risico op ongelukken in zich dragen. Voor inhalen geldt dat laatste ook maar het eerste niet steeds.

Feiten en omstandigheden die bijdragen aan de schuld moeten voor de verdachte kenbaar zijn, dat wil zeggen: de verdachte heeft deze kunnen en moeten kennen. Het is bij de culpa ten aanzien van het gevolg immers blijven gaan om niet voorzien waar men had behoren te voorzien, ook al is de voorzienbaarheid door de veelheid aan veiligheidsvoorschriften op de achtergrond geraakt (zie 3.6).

Maatstaf voor wat men had kunnen en behoren te (voor)zien is de gemiddelde burger. Gaat het om gedrag in een situatie waarvoor enige opleiding is vereist - industrie, verkeer, medisch beroepsveld - dan geldt als uitgangspunt hetgeen van een gemiddelde, ter zake opgeleide functionaris in de concrete omstandigheden van het geval kan worden verwacht. Zijn functie brengt een zekere Garantenstellung ${ }^{542}$ mee. Een en ander betekent dat ook bij het oordeel over de aanmerkelijkheid der schuld de gemiddelde burger c.q. ter zake opgeleide functionaris centraal staat.

Beschikt iemand over meer kennis, ervaring of deskundigheid dan pleegt dat te zijnen nadele te worden meegewogen, ook in het kader van de vraag naar het aanmerkelijke der schuld. Die persoonlijke kenmerken kunnen immers meebrengen dat men beter weet waarop te letten c.q. waarop men bedacht moet zijn dan iemand die niet over dit surplus aan wetenschap, ervaring en/of deskundigheid beschikt. Toch ligt hier een misverstand op de loer. Ook een behoorlijke opleiding en/of meer dan gemiddelde kennis, ervaring of deskundigheid brengen nog niet mee dat een enkele momentane onoplettendheid aanmerkelijke schuld oplevert. Daarvoor is een momentane onoplettendheid - zoals hierna onder 5.II aan de orde komt - te veel in het wezen van de mens 'ingebakken'.

Maar hoe nu wanneer iemand wel aan de opleidingseisen voldoet maar nog weinig ervaring heeft opgedaan dan wel door zijn leeftijd minder goed is opgewassen tegen complexe situaties? Dienen laatstgenoemde omstandigheden ook betrokken te worden bij het oordeel over het aanmerkelijke van de schuld? Naar mijn mening wel. De aanmerkelijke schuld behelst een op de persoon toegesneden verwijt. Dat betekent dat niet alleen meeweegt dat hij beter maar ook dat hij minder dan de gemiddelde burger of functionaris in staat was tot adequate oplettendheid of voorzichtigheid. Onder omstandigheden valt niet uit te sluiten dat genoemde 'gebreken' iemand ertoe nopen niet op te treden als OK-verpleegkundige of bij duisternis niet te rijden. Dan verschuift het schuldverwijt naar onvoorzichtigheid, bestaande in het optreden als OK-verpleegkundige of het deelnemen aan het verkeer en zal moeten worden

542 Zie over de nadruk op de Garantenstellung in de risicomaatschappij D. Roef, Strafrechtelijke verantwoordelijkheid in de risicomaatschappij, in: Veiligheid of vergelding?, onder redactie van P.L. Bal e.a., p. 44 . 
nagegaan of van die onvoorzichtigheid kan worden gezegd dat deze aanmerkelijk was. Daarbij speelt de hierna onder 5.II te bespreken achtergrond waartegen het schuldoordeel wordt c.q. moet worden geveld een belangrijke rol.

\subsubsection{Geoorloofd risico}

De nadruk bij de vereiste mate van schuld op het gebrek aan voorzorg doet de vraag rijzen hoe ver die voorzorgen dienen te gaan. Van iemand wordt niet verlangd dat hij ieder risico voor eventuele gevolgen van zijn gedrag uitbant. Zou dit anders zijn dan zou op velerlei terrein het maatschappelijk verkeer ernstig in zijn functioneren worden gehinderd. Zou van een machinist worden gevergd dat hij een trein voor vertrek op alle mogelijke gebreken controleert dan zou dat de capaciteit van het spoorwegverkeer ernstig schaden. Hij kan dus volstaan met een blik op zijn controlepaneel. Pas als dat aangeeft dat er met de essentiële functies van de trein iets mis is, zal hij moeten beslissen of vertrekken verantwoord is. Dienstvoorschriften die bepalen met welke gebreken wel, met welke niet mag worden gereden zijn hem daarbij tot steun. In die dienstvoorschriften ligt besloten welk risico de leiding van het spoorbedrijf aanvaardbaar vindt. Daar mag hij zich in beginsel naar richten. Bijzondere omstandigheden kunnen dit anders maken.

Welk risico geoorloofd is, valt niet steeds eenvoudig na te gaan. Uit een geheel van voorschriften - regels voor het wegverkeer, dienstvoorschriften, richtlijnen van beroepsorganisaties - valt tot op zekere hoogte op te maken welk risico niet, welk risico wel aanvaardbaar pleegt te worden geacht. Wie bij zijn doen of laten de voorgeschreven voorzorgen niet in acht neemt, geeft aanknopingspunt voor het aanmerkelijke van de schuld wanneer door zijn onachtzaamheid dood of letsel optreedt. Daarbij dient echter bedacht te worden dat het in concreto heel wel anders kan liggen. Er zijn een veelheid aan situaties denkbaar waarin het gelet op andere op het spel staande belangen verantwoord, soms noodzakelijk is niet alle voorgeschreven voorzorgen in acht te nemen. Zo kan het zijn dat op een overbelaste afdeling spoedeisende hulp niet alle voorgeschreven voorzorgen in acht kunnen worden genomen omdat anders ernstig zieke of gewonde patiënten te lang op behandeling moeten wachten. Hier wordt evenwichtskunst gevraagd in situaties die tot rustig nadenken en afwegen juist geen behoorlijke gelegenheid bieden.

In het wegverkeer heeft het geoorloofd risico uitdrukking gevonden in het vertrouwensbeginsel: ${ }^{543}$ wie zichzelf aan de regels houdt mag er - behoudens aanwijzingen in concreto voor het tegendeel - van uitgaan dat andere weggebruikers dat ook doen. Het beginsel vormt de smeerolie voor een vlotte en soepele afwikkeling van het wegverkeer. Daarmee wordt ook de kern geraakt van het verschijnsel van het geoorloofd risico. In dit begrip ligt een afweging besloten van het belang van de veiligheid van anderen tegen - kort gezegd - het belang van het goed functioneren van het maatschappelijk verkeer op alle terreinen waarop de door culpoze

543 O.a. H. de Doelder en A.C. 't Hart, Het vertrouwensbeginsel in het verkeersrecht, VR I977, p. I45 e.v. 
gevolgsdelicten beschermde belangen spelen: verkeer, industrie, gezondheidszorg etc.

\subsubsection{Culpa ten aanzien van een strafbaarheid constituerende omstandigheid}

Delicten waarin de culpa is gericht op enige omstandigheid die de beschreven gedraging strafwaardig maakt, komen in twee vormen voor. Er zijn delicten waarin opzet en culpa ten aanzien van een dergelijke omstandigheid naast elkaar zijn opgenomen - 'weet of redelijkerwijs moet vermoeden' etc.544 - en voor de maximumstraf niet van belang is of van de vereiste opzet of culpa sprake is, er zijn delicten waarin louter culpa ten aanzien van die omstandigheid wordt geëist (bijv. art. 4I $\mathrm{Ibis} \mathrm{Sr}$ ). Dit roept de vraag op of de vereiste mate van schuld tussen beide typen delicten verschilt. Het lijkt immers niet te gewaagd te veronderstellen dat waar opzet en culpa naast elkaar figureren en de wet voor wat betreft de maximumstraf niet differentieert naar opzet en culpa, een hogere graad van culpa wordt geëist dan waar louter culpa ten aanzien van een omstandigheid wordt gevergd. Een algemene uitspraak valt hierover echter niet te doen.

Van het 'redelijkerwijs had moeten vermoeden' in art. 4I7bis Sr (schuldheling) weten we dat hierin handelen met aanmerkelijke onvoorzichtigheid als vereiste besloten ligt. ${ }^{55}$ Het ligt voor de hand te veronderstellen dat waar de wetgever dezelfde of een verwante terminologie bezigt, ook van aanmerkelijke onvoorzichtigheid moet worden uitgegaan.

Gelet op het verschil in aard van de delictsomschrijvingen waarin culpa ten aanzien van een omstandigheid wordt gevraagd valt niet eenvoudig een nadere omlijning van de vereiste aanmerkelijke schuld te geven. In zijn algemeenheid valt te zeggen dat 'van de domme houden' geen goede remedie lijkt tegen strafrechtelijke aansprakelijkheid. Juist daarin ligt vaak het strafrechtelijke verwijt, te beoordelen naar de concrete omstandigheden van het geval en de wijze waarop de culpa is tenlastegelegd. Soms kan zelfs het niet-weten waar men behoorde te weten meebrengen dat men heeft gehandeld in het besef van de aanmerkelijke kans dat de omstandigheid waarop de culpa betrekking heeft zich voordeed en onder omstandigheden zelfs dat men die kans bewust op de koop toenam en dus handelde met (voorwaardelijk) opzet op die omstandigheid..$^{546}$ Wellicht ligt daarin de verklaring voor het feit dat de wetgever door in één adem strafbaar te stellen het weten en het ernstige reden hebben om te vermoeden etc. qua strafwaardigheid kennelijk niet steeds verschil lijkt te zien tussen de doleuze en de culpoze variant van dergelijke delicten. Bij die delicten heeft de wetgever zich kennelijk niet laten leiden door het verschil in strafwaardigheid van de opzettelijke en de culpoze variant van die delicten maar prioriteit gegeven aan het treffen van een voorziening voor moeilijkheden bij het bewijs ${ }^{547}$ van het weten waaronder doorgaans overigens ook het voorwaardelijk opzet pleegt te wor-

544 Art. 227a, 227b, 248c, 362 e.v. Sr.

545 HR I7 januari 20II, LJN BU42II en HR 5 juli 20II, LJN BQ6I40, NJ $2011,327$.

546 Vgl. HR 3 november 2009, LJN BJ6944.

547 J. de Hullu, Materieel strafrecht, Deventer: Kluwer 20I2, vijfde druk, p. 258. 
den begrepen. ${ }^{548}$ Bij dergelijke delicten zal de rechter in de strafmaat moeten differentiëren naar de opzettelijke en de culpoze variant van zo'n delict. Mogelijk kan de verhouding tussen de straffen op heling (art. 4I6 Sr) en schuldheling (art. 4I7bis Sr) - qua vrijheidsstraffen een verhouding van vier op één - hier enig aanknopingspunt verschaffen.

\subsubsection{Medeschuld}

Culpoze gevolgsdelicten plegen zich af te spelen op terreinen waarop meerdere mensen werkzaam zijn of waarop verschillende mensen zich bewegen. Daarom kan het zijn dat onachtzaamheid van verschillende personen ieder voor zich tot dood of letsel leidt, dat wil zeggen dat de dood of het letsel als gevolg kan worden toegerekend aan de onachtzaamheid van ieder van die personen. Het slachtoffer kan een van die personen zijn. ${ }^{549}$ Dit betekent niet dat de onachtzaamheid van anderen voor de mate van schuld van de verdachte niet van belang is. Het kan zijn dat de verdachte met die onachtzaamheid rekening had moeten houden en deze dus niet afdoet aan de mate van verdachtes schuld of daaraan bijdraagt. Het doet zich ook voor dat de verdachte die onachtzaamheid van de ander in de hand heeft gewerkt: (veel) te snel rijden op een voorrangsweg waardoor de kans toeneemt dat een voorrangsplichtige bestuurder het voertuig van de voorrangsgerechtigde bestuurder over het hoofd ziet of de snelheid daarvan verkeerd inschat. Ook dan neemt de - in wezen fatale onachtzaamheid van de derde verdachtes onachtzaamheid niet weg doch scherpt deze eerder in. Kijken we in het voorgaande voorbeeld naar de voorrangsplichtige bestuurder dan heeft het gedrag van de voorrangsgerechtigde bestuurder het voor hem juist moeilijker gemaakt om aan zijn voorrangsplicht te voldoen. Daardoor vormt het gedrag van de voorrangsgerechtigde bestuurder een factor die de mate van schuld van de voorrangsplichtige bestuurder vermindert, ${ }^{50}$ tenzij hij met dat gedrag rekening had moeten houden..$^{55}$

548 HR ig januari 1993, LJN ADi8I2, NJ I993, 49I (art. 4I6 Sr) en HR 3 december 2002, LJH AE89o8, NJ 2003, 353, NbSr 2003, 2I (art. 243 Sr), HR 30 mei 2008, LJN BC8673 (t.a.v. art. 362 en 363 Sr).

549 E.M. Witjes, Strafrechtelijke causaliteit, diss. Groningen 20II, p. I55 e.v.

550 Zie ook de organisatorische gebreken die in het in 4.6 besproken HR I2 juni 2012, LJN BW7948 (landmachtdemonstratie) maakten dat van aanmerkelijke schuld geen sprake was.

55I Zie hierover uitgebreider Gevaar en schuld op de weg, p. I36 e.v. Zie over de betrekkelijke betekenis van de vermijdbaarheidsberekening, die in het kader van de vraag naar medeschuld pleegt te worden uitgevoerd, VR 2005, p. 173 (n.a.v. HR I8 mei 2004, VR 2004, II7) alsmede A.C.E. Spek, Causaliteit bij voorrangsongevallen, VR 2007, p. 38, 39. W. den Harder, Aanmerkelijk onvoorzichtig. De ondergrens van de schuld in het verkeersstrafrecht, diss. Rotterdam 2006 pleit er - onder verwijzing naar het privaatrecht - voor de mate van schuld te relateren aan de causale bijdrage die de verdachte heeft geleverd aan het ontstaan van het ongeval $($ hs. 6,7$)$. 


\section{II De achtergrond waartegen het schuldoordeel wordt c.q. moet worden geveld}

\subsubsection{Inleiding}

Het schuldoordeel wordt niet alleen geveld op grond van alle omstandigheden van het concrete geval maar ook tegen de achtergrond van feiten van algemene bekendheid, algemene ervaringsregels en opvattingen over hetgeen in het algemeen van burgers in de huidige samenleving of een specifiek deel daarvan, mede in het licht van het geheel aan toepasselijke wettelijke voorschriften of het - soms desbewustontbreken van een voorziening bij wet, mag worden gevergd. Deze verdienen afzonderlijk aandacht omdat zij soms bepalend zijn voor de uitkomst van het schuldoordeel.

\subsubsection{Culpoze gevolgsdelicten in het wegverkeer}

Een element dat een rol speelt bij de begroting van de mate van schuld, is de omstandigheid dat onoplettendheid of onvoorzichtigheid zelden tot ernstige gevolgen pleegt te leiden. Onoplettendheid en onzorgvuldigheid zijn in het verkeer aan de orde van de dag maar leiden zelden tot een dodelijk ongeval. Volgens het Jaaroverzicht 2002 van het Bureau Verkeershandhaving OM zijn te snel rijden en rijden door rood licht naast het negeren van de wettelijke alcohollimiet en de gordel- en helmdraagplicht de belangrijkste oorzaken ${ }^{552}$ van ongevallen in het verkeer. Daarom wordt de handhaving van verkeersregels met name gericht op het tegengaan van genoemde misdragingen. Onder de miljoenen op grond van de Lex Mulder553 opgelegde verkeersboetes die het CJIB jaarlijks verwerkt en die per definitie (zie art. 2 lid 2 WAHV) niet tot schade of erger hebben geleid zijn bijvoorbeeld (2007-20II) bijna 240.000 tot ruim 320.000 gevallen van rijden door rood licht, en bijna (200I2006) zeven miljoen snelheidsovertredingen, waarvan ca. I $8 \%$ (ruim I,2 miljoen) II-I5 km/u te snel, ca. $9 \%$ (ruim o,6 miljoen) I6-20 km/u te snel, en ruim 7,5\% (ruim $500.000) 2 \mathrm{I}-40 \mathrm{~km} / \mathrm{u}$ te snel.554 Voorts behandelde het CJIB in $2002 \mathrm{I} 30.000$ politietransacties ten aanzien van grove snelheidsovertredingen ( $>40 \mathrm{~km} / \mathrm{u}$ ) die kennelijk ook niet tot ernstige gevolgen hebben geleid. Worden deze aantallen afgezet tegen het aantal personen dat thans jaarlijks gemiddeld bij verkeersongevallen om het leven komt, ca. 66I, ${ }^{555}$ en wordt voorts bedacht dat het hier gaat om aantallen geconstateerde overtredingen en niet om aantallen gepleegde overtredingen, ${ }^{55}$ dan ligt

552 Bedoeld zal zijn dat het negeren van de gordel- en helmdraagplicht niet de oorzaak is van ongevallen maar de gevolgen ervan verergert.

553 Wet administratiefrechtelijke handhaving verkeersvoorschriften.

554 http://www.swov.nl/NL/Research/cijfers/Toelichting-gegevensbronnen/Verkeersovertredingen.html.

555 http://www.om.nl/onderwerpen/verkeer/actueel/@158773/lichte-stijging/.

556 In dit verband spreekt de opmerking in het Jaaroverzicht 2002, p. I8, dat op kruispunten waar een roodlichtcamera is geplaatst het aantal weggebruikers dat door rood licht rijdt daalt tot minder dan $\mathrm{I} \%$, boekdelen. 
de conclusie voor de hand dat er belangrijke aanwijzingen zijn dat het hoofdzakelijk een kwestie van - noodlottig - toeval is wanneer enige onoplettendheid of onvoorzichtigheid leidt tot een ongeval met dood of zwaar lichamelijk letsel als gevolg. 557

Er zijn nog meer elementen die een weggebruiker die onoplettend of onvoorzichtig is, niet in de hand heeft. De inrichting van de weg zoals middenbermbeveiliging, de constructie van voertuigen zoals kooiconstructies en kreukelzones, en door medeweggebruikers genomen beschermende maatregelen als autogordel en valhelm ${ }^{55^{8}}$ zijn in belangrijke mate bepalend voor de afloop van een ongeval en daarmee voor de vraag of een onoplettendheid of onvoorzichtigheid leidt tot een ongeval met dood of zwaar lichamelijk letsel tot gevolg. Verkeerslichten of rotondes kunnen ernstige voorrangsongevallen voorkomen, ${ }^{559}$ dodehoekspiegels kunnen een belangrijke bijdrage leveren aan het terugdringen van ernstige ongevallen door afslaand vrachtverkeer. ${ }^{60}$

Bij de bepaling van de mate van schuld in geval van onoplettendheid of onvoorzichtigheid in het verkeer kan niet worden voorbijgegaan aan de eisen die van overheidswege aan verkeersdeelnemers worden gesteld. Wie op zijn achttiende jaar zijn rijbewijs heeft behaald wordt nimmer meer aan enige proeve van bekwaamheid onderworpen. Jongeren worden tot deelname aan het gemotoriseerd verkeer toegelaten ook al zijn zij onevenredig vaak bij ongevallen betrokken. ${ }^{56 \mathrm{r}}$ Voor ouderen geldt hetzelfde. ${ }^{62}$ Hoewel bekend is dat met name complexe verkeerssituaties oudere verkeersdeelnemers tot het maken van fouten brengen, worden ook zij niet aan enige rijvaardigheidsproef onderworpen. In wezen worden dus aan bestuurders geen hoge eisen gesteld. Dit typeert de plaats die deelname aan het gemotoriseerde wegverkeer in de samenleving heeft verworven: het maakt deel uit van het normale levenspatroon en is niet voorbehouden aan personen die het besturen van motorvoertuigen als beroep hebben. Daarmee verliest het argument van de Garantenstellung ter onderstreping van de eisen die aan de gemotoriseerde weggebruiker worden gesteld enige glans. Uit een oogpunt van Garantenstellung kunnen tegen de hiervoor geschetste achtergrond aan die weggebruiker minder hoge eisen worden gesteld dan aan een machinist of een verpleegster, functionarissen die bij uitstek zijn opgeleid en aangesteld met het oog op een zorgvuldige vervulling van hun taak.

557 Zie ook de berekening van Van Dijk, a.w., p. 51-54 over de zeer kleine kans dat te snel rijden op een voorrangsweg op een kruising leidt tot een ongeval, laat staan tot een dodelijk ongeval.

558 Zie www.swov.nl/kennisbank over de oorzaken van het sterk teruglopen van het aantal doden per miljard voertuigkilometer (van ca. I50 in I950 naar ca. Io in 2000, ondanks de sterk gestegen mobiliteit).

559 Rotonde: de veiligste kruising, op www.swov.nl/kennisbank. Voorts: Ook op lange termijn een veilige oplossing: Rotondes bevorderen verkeersveiligheid, in swovschrift 66 - maart I996 (www.swov.nl/nl/kennisbank).

560 Zie Nota van toelichting op het Besluit van 9 oktober 2002 houdende wijziging van het Voertuigreglement in verband met het verplicht stellen van bepaalde gezichtsveldverbeterende voorzieningen voor bedrijfsauto's, Stb. 2002, 547. Zie met name art. 5·3.45a Voertuigreglement. Zie ook Kamervragen met antwoord 2003-2004, nr. 2: Vragen van Dijksman aan de minister van Verkeer en Waterstaat over de mogelijke invoering van de dodehoekspiegel voor vrachtwagens (28 augustus 2003).

56I www.swov.nl/kennisbank.

$562 \mathrm{Zij}$ zijn met name vaker betrokken bij kruispuntongevallen: www.swov.nl/kennisbank. 
Ook het besef dat een bestuurder die een ernstig ongeval heeft veroorzaakt een fout heeft gemaakt die een willekeurige andere bestuurder evenzeer had kunnen maken speelt wel een rol bij de beantwoording van de vraag of sprake is van schuld in een mate die als aanmerkelijk kan worden gewaardeerd. Het besef van deze feilbaarheid en de ernst van de gevolgen die deze kan hebben heeft er bijvoorbeeld toe geleid dat spoorwegmaatschappijen technische voorzieningen treffen om te voorkomen dat een trein door een rood sein rijdt, ook al worden treinen bestuurd door personen wier professie het is dit te voorkomen en van wie het gehoorzamen van een rood sein een uitgesproken essentieel onderdeel vormt van de wijze waarop zij hun functie dienen uit te oefenen.

Voorts mag hier niet ongenoemd blijven dat bestuurders die door het maken van een verkeersfout een ander zwaar lichamelijk letsel hebben toegebracht of die de dood van een ander hebben veroorzaakt, niet zelden zwaar gebukt gaan onder de gevolgen van hun gedrag en dat zij niets liever zouden willen dan dat deze waren voorkomen. Dat doet aarzelen omtrent de zin van vervolging en bestraffing ${ }^{563}$ hoewel deze heel wel kan worden gevonden in het publiekelijk demonstreren van het handhaven van de strafwet, de behoefte van slachtoffers en/of nabestaanden aan een onafhankelijk oordeel over hetgeen er fout is gegaan, in het publiekelijk vergelden van het leed dat hun is aangedaan, alsmede in de mogelijkheid voor slachtoffers als benadeelde partij een eenvoudig te bepalen deel van de schade te verhalen.

\subsubsection{Andere culpoze gevolgsdelicten}

De ontwikkelingen die hiervoor zijn beschreven als achtergrond waartegen culpoze delicten in het verkeer dienen te worden beoordeeld, zijn ook van belang voor de beoordeling van andere culpoze gevolgsdelicten. Tot op zekere hoogte spelen deze zich immers af tegen een vergelijkbare achtergrond: trein- en luchtverkeer, scheepvaartverkeer. Maar ook op andere terreinen waar culpoze gevolgsdelicten plaats vinden - werk, sport etc. - zijn deze ontwikkelingen van belang. Zij laten zien dat steeds in het oog moet worden gehouden dat een mens uit de aard van zijn wezen feilbaar is, dat dit geen reden pleegt te zijn om af te zien van gedragingen waaraan gevaren zijn verbonden - werken met machines etc. - en dat tot op zekere hoogte ook wordt geaccepteerd dat hieraan ernstige gevolgen verbonden kunnen zijn. Fascinatie voor en economisch belang van nieuwe mogelijkheden geven veelal de doorslag. Daar staat tegenover dat met het oog op die gevaren redelijke voorzorgen plegen te worden gevergd. Aard en omvang van die voorzorgen zijn weer afhankelijk van de mogelijkheden tot het treffen van voorzorgen. Stand van de techniek en de maatschappelijke kosten van die voorzorgen ${ }^{54}$ leggen daarbij een belangrijk gewicht in de schaal.

563 Zie zeer kritisch over de strafwaardigheid van onbewuste culpa G.E. Langemeijer, Strafrecht of -onrecht, Kluwer 1975, p. 53, 54. Zie hierover ook Janekwski, a.w. p. 165, I66, die suggereert de vervolging ter zake van dood of lichamelijk letsel door schuld te beperken tot gevallen van 'Leichtfertigkeit oder große Fahrlässigkeit'.

564 Een wel heel wrang voorbeeld vormt het hiervoor in 4.6 besproken, aan HR I2 juni 20I2, LJN BW7948 ten grondslag liggende geval, waarin uit een oogpunt van kostenbesparing was 


\subsubsection{Acceptatie van risico}

Met de hiervoor beschreven acceptatie van risico is het vreemd gesteld. In abstracto is men vaak bereid deze te aanvaarden, in concreto niet. ${ }^{65}$ Een pikant voorbeeld vormt de verhoging van de maximumsnelheid op autosnelwegen. Deze wordt ingevoerd in de wetenschap dat de kans op dodelijke ongevallen toeneemt terwijl tegelijk het streven erop gericht is het aantal dodelijke ongevallen in het wegverkeer terug te dringen. Voorts zien we dat het terugbrengen van het ene risico het andere kan oproepen of versterken. Teneinde het aantal dodelijke ongevallen met auto's terug te dringen wordt ernaar gestreefd de veiligheid van personenauto's te verhogen..$^{566}$ Dit lukt door de carrosserie van personenauto's door middel van een zgn. kooiconstructie te verstevigen maar dit leidt er tegelijk toe dat de raamstijlen van de voorruit dikker worden en de dode hoek van personenauto's met het daaraan verbonden gevaar op ongevallen wordt verhoogd..$^{67}$

Om de dode hoek bij vrachtwagens - een oorzaak van ernstige ongevallen - te reduceren worden vrachtwagens van meer spiegels voorzien, tot wel zeven toe. Dat lijkt de veiligheid te vergroten maar vergt zoveel (kijk)handelingen dat de verkeerssituatie al weer kan zijn veranderd op het moment dat de chauffeur goed in alle spiegels heeft gekeken. ${ }^{58}$

\subsubsection{Hetgeen bekend is omtrent capaciteiten van mensen}

Aan de eisen die in het kader van de aanmerkelijke schuld aan mensen worden gesteld liggen vooronderstellingen ten grondslag over capaciteiten van mensen, over hetgeen zij kunnen waarnemen en over hetgeen zij aan waarnemingen kunnen verwerken. Deze vooronderstellingen worden zelden geëxpliciteerd en/of aan onderzoek onderworpen terwijl deze voor de uitkomst van het oordeel over de aanmerkelijke schuld van doorslaggevend belang zijn. Möhler e.a. ${ }^{569}$ wijzen er bijvoorbeeld op dat een donkergrijs geklede voetganger voor de bestuurder, bij duisternis rijdend met dimlicht, op twee keer zo grote afstand te zien is als een zwart geklede persoon. Niettemin speelde noch in HR 29 april 2008, LJN BDo709570 (bij donker botsen op

gekozen voor een wijze van doorsnijden van afdaallijnen die - naar achteraf bleek - fouten bij het doorsnijden in de hand werkte.

${ }^{6} 65$ Zo ook Roef, a.w., p. 5I, die spreekt van een zekere tweeslachtigheid van onze risicomaatschappij.

566 Zie o.a. http://nl.euroncap.com/.

567 http://www.mosac.eu/veilig-motorrijden/onze-problemen-ongevalrapporten/wat-zijn-onzeproblemen/we-worden-niet-gezien/dodelijke-a-stijlen/, http://www.mosac.eu/public/file/Bike\%2oMagazine\%2oKiller\%2opillars.pdf, http://www.autoglassnews.co.uk/index.php?id=killer-pillar-facts-and-stats.

568 Zie K. van Eekelen, De nachtmerrie van iedere vrachtwagen(bus)chauffeur, Verkeersknooppunt november/december 20II, p. I6, I7, alsmede SWOV factsheet Dodehoekongevallen, te vinden op http://www.swov.nl/rapport/Factsheets/NL/Factsheet_Dodehoekongevallen.pdf, in het bijzonder p. 5 .

569 In Jochen Buck, Helmut Krumbholz [Hrsg.], Sachverständigenbeweis im Verkehrsrecht (Unfallrekonstruktion, Biomechanik, Messtechnik, Bildidentifikation, Alkohol und Drogen), BadenBaden: Nomos Verlaggesellschaft 2008, p. 46.

570 NJ 2008, 439, m.nt. N. Keijzer onder NJ 2008, 442. 
een op de rijbaan zittende persoon) noch in HR 22 november 20II, LJN BR3005 37 I (bij donker plotseling overstekende voetganger op weg met straatverlichting) de kleur van de kleding van de aangereden persoon enige rol. Aarts ${ }^{572}$ heeft onderzoek gedaan naar de vraag in hoeverre mensen in een complexe mens-machine omgeving overzicht kunnen houden over alle informatie die zij krijgen en daar hun gedrag op kunnen afstemmen. Dat onderzoek bestond in bestudering van de wijze waarop de wachtofficier op de brug van een schip omgaat met alle informatie die hij ontvangt en welke de invloed daarop is van incidenten die zijn specifieke aandacht vragen. Ook bij ervaren wachtofficieren bleken incidenten tot aandachtsvernauwing te leiden met als gevolg dat niet alle informatie meer die aandacht kreeg die noodzakelijk was. Kennelijk liepen de wachtofficieren hier aan tegen de grenzen van waartoe een mens in staat is.

Opmerkelijk is ook hetgeen Vink en Van Koppen ${ }^{573}$ schrijven naar aanleiding van vrijspraak van dood door schuld van de 'zekeraar' van de beklimster van een klimwand, die niet steeds zijn ogen op haar gericht had en zijn karabiner al had losgemaakt voordat zij veilig op de grond stond. ${ }^{574}$ Het hof had daarbij overwogen dat verdachte een zeer ervaren zekeraar was en dat het zekeren van de klimster berustte op een geautomatiseerde reeks van handelingen. Vink en Van Koppen achten deze vrijspraak vanuit psychologisch oogpunt juist, omdat - kort gezegd - skill-based gedrag minder ongelukken oplevert dan gedrag waarover men bewust nadenkt en iemand dan niet moet worden verweten dat hij zich - zoals in het onderhavige geval - ondanks zijn skill-based gedrag heeft laten afleiden door hetgeen naast hem gebeurde.

De hiervoor beschreven voorbeelden zijn min of meer toevallig gevonden. Zij wijzen erop dat in het kader van het oordeel van de aanmerkelijke schuld meer aandacht dient te komen voor hetgeen andere wetenschappen leren over capaciteiten van mensen, over hetgeen zij kunnen waarnemen en over hetgeen zij aan waarnemingen kunnen verwerken. ${ }^{575}$ De kans op onjuiste vooronderstellingen daarover onder invloed van de ernst van de gevolgen en de hierna te bespreken hindsight bias kan niet licht worden overschat.

57 I NJ 20I2, I75, m.nt. B.F. Keulen.

572 L. Th. Aarts, Overview maintenance in man-machine environments, diss. UvA 2004.

573 http://www.nrc.nl/rechtenbestuur/20I2/02/23/de-uitspraak-ben-je-strafbaar-als-je-perongeluk-je-klimpartner-afkoppelt-die-daarna-valt/ d.d. 23 februari 2012.

574 Zie HR 7 februari 20I2, LJN BU2878, NJ 20I2, II9; de Hoge Raad verwierp het beroep van het Openbaar Ministerie tegen de vrijspraak.

575 Zie over het betrekken van kennis uit empirische wetenschappen in het privaatrecht T. Hartlief, Het nieuwe privaatrecht, NJB 20I2, p. I38I, alsmede Vranken bij HR 5 juni 2009, NJ 20I2,I82-I84 en Van Boom, Giesen en Smits (red.), Civilologie: opstellen over empirie en privaatrecht, Den Haag 20I2, waarnaar Hartlief verwijst. Zie voorts J.B.M. Vranken in: De Hoge Raad in 2025, Contouren van de toekomstige cassatierechtspraak, onder redactie van A.M. Hol e.a., Den Haag: Boom Juridische uitgevers 20II, p. 46. 


\subsubsection{Hindsight bias of achteraf is het makkelijk praten}

Dossiers in zaken van culpoze gevolgsdelicten hebben veelal iets beklemmends. Met de wetenschap van het ongeval dat heeft plaatsgevonden springt in het oog waar iemand is tekortgeschoten. Dat bergt het gevaar in zich dat achteraf veel zwaarder wordt getild aan iemands onoplettendheid of onvoorzichtigheid dan men, onwetend van het verloop van de gebeurtenissen en de gevolgen van de onoplettendheid of onvoorzichtigheid, zou hebben gedaan. ${ }^{576}$ Dit gevaar ligt ook besloten in de redenering dat het gevolg van de onoplettendheid zo ernstig is dat die onoplettendheid wel aanmerkelijk moet zijn geweest. De Hoge Raad heeft die redenering dan ook uitdrukkelijk een halt toegeroepen door te overwegen dat niet reeds uit de ernst van de gevolgen kan worden afgeleid dat sprake is van aanmerkelijke schuld. 577

Van Dijk noemt in dit verband ook nog de neiging van de mens bij het schuldoordeel persoonlijke factoren zwaarder te wegen dan situationele factoren. 'Een dodelijk verkeersongeval wordt eerder geweten aan een gevaarlijke attitude dan aan de omstandigheden van het geval'. ${ }^{578}$

\subsubsection{Samenleving en risico}

Het gevaar voor 'hindsight bias' wordt versterkt door de wijze waarop in de tegenwoordige samenleving met risico's pleegt te worden omgegaan. Anders dan in een tijd waarin men niet beschikte over (technische) middelen om risico's van overigens aanvaardbaar of wenselijk menselijk gedrag beheersbaar te maken of zoveel mogelijk uit te bannen, bestaat er een neiging risico's van dat gedrag niet aanvaardbaar te achten, zeker niet wanneer deze zich hebben verwezenlijkt. 'Kenmerkend (...) is dat de samenleving in de ban is van het willen weren van risico's en het vermijden van gevaren. ${ }^{579}$ Daar komt bij dat de samenleving zo complex is geworden dat we voor het vermijden of verminderen van risico's in belangrijke mate afhankelijk zijn geworden van de inspanning van derden, van de overheid, van bedrijven of van personen.

Ieder ongeval van betekenis is nieuws. Berichten, hoe langer hoe meer voorzien van door (toevallig) ter plaatse aanwezige burgers vervaardigde foto's en filmpjes, ${ }^{580}$ worden door de pers over allerhande media verspreid, gevolgd door de vraag hoe dit heeft kunnen gebeuren. Dit versterkt het bewustzijn van de risico's die we in het dagelijks leven lopen en roept de behoefte op deze risico's zoveel mogelijk te beperken en dus te zoeken naar een verklaring voor een ongeval, om op basis daarvan maatregelen te kunnen nemen ter voorkoming in de toekomst. ${ }^{{ }^{81} \mathrm{r}}$ Voor het besef

576 Zie over dit gevaar o.a. Van Dijk, a.w., p. 178 e.v.

577 HR I juni 2004, LJN AO5822, NJ 2005, 252, m.nt. G. Knigge (Winssen).

578 A.w., p. I8o.

579 F.W. Bleichrodt, Beperking van bewegingsvrijheid en beïnvloeding van gedrag in het Nederlands straf-en strafprocesrecht, preadvies NVVS 20II, p.Io.

580 Zie bijv. http://nos.nl/assets/ooggetuige/.

58I In deze zin ook Van der Woude en Van Sliedregt, in het hierna in noot 582 genoemde artikel, p. 222. 
van een ongelukkige samenloop van omstandigheden als oorzaak lijkt niet veel ruimte (meer) te zijn. Er moet iets of iemand zijn waaraan of aan wie het ongeval kan worden toegeschreven.

Roef $^{582}$ ziet als gevolg van de door hem aan de hand van de theorie van Beck beschreven ontwikkeling van de huidige maatschappij naar een risicosamenleving, waarin het zoveel mogelijk beperken van de gevaren van het moderne leven op de voorgrond staat, dat het strafrecht is geëvolueerd van een retrospectief, vergeldend schuldstrafrecht naar een meer prospectief, generaalpreventief risicostrafrecht. Voor wat betreft culpoze delicten doet deze ontwikkeling zich in zijn ogen voelen in een zwaarder tillen aan de Garantenstellung en een tendens naar extensievere normativering van het schuldvereiste, ertoe leidend dat wordt geabstraheerd van de feitelijke, psychische aspecten van de schuld. ${ }^{83}$

Inmiddels - Roef schreef zijn essay in 2003 - weten we uit het hiervoor besproken HR 29 april 2008, LJN BD0544 (Geervliet) ${ }^{584}$ dat louter niet voldoen aan de te verwachten Garantenstellung voor culpa niet voldoende is en heeft de Hoge Raad - zoals ook in het in 4.4 besproken HR I juni 2004, LJN AO5822, NJ 2005, 252, m.nt. G. Knigge (Winssen) - laten zien dat niet zonder meer kan worden geabstraheerd van de subjectieve aspecten van de schuld. Daarmee lijkt de Hoge Raad ter bescherming van de individuele burger afstand te nemen van de verlangens die een risicosamenleving oproept. Dat lijkt mij juist..$^{55}$ Een veroordeling ter zake van een culpoos gevolgsdelict behelst een zwaar persoonlijk verwijt. Daaraan kan niet worden voorbijgegaan ter wille van het tegemoet komen aan het streven naar het beperken van risico's van het leven van alledag. Andere rechtsgebieden leveren daarvoor betere instrumenten, zoals het civiele recht. Dat kent mogelijkheden een persoon voor zijn of haar tekortschieten aansprakelijk te stellen zonder dat dit een zwaar persoonlijk verwijt behelst met de daaraan (veelal) verbonden diepe ingreep in iemands persoonlijke vrijheid.

De toegenomen aandacht voor het zoveel mogelijk beperken van de risico's die het leven in de huidige samenleving meebrengt, heeft zich - aldus Roef $5^{86}$ - ook vertaald in een toegenomen aandacht voor de belangen van het slachtoffer. Hoewel het vereiste van de aanmerkelijke schuld kan meebrengen dat iemand vrijuit gaat, ook al heeft hij enige fout gemaakt die heeft geleid tot het fatale gevolg (zie 5.13) en een slachtoffer of diens nabestaanden zich daardoor miskend kunnen voelen, is dat in mijn ogen geen reden om het vereiste van het aanmerkelijke van de schuld te laten

582 D. Roef, Strafrechtelijke verantwoordelijkheid in de risicomaatschappij, in: Veiligheid of vergelding?, onder redactie van P.L. Bal e.a., p. 33-56. Zie ook Maartje van der Woude en Elies van Sliedregt, De risicosamenleving: overheid vs. strafrechtswetenschap? Aanwijzingen voor het debat rondom veiligheid en risico's, Proces 2007, p. 216-226, en C.P.M. Cleiren, Zorgen voor morgen. Bescherming van privacy in het strafrecht in een veranderend veiligheidslandschap, Strafblad 2009, p. II2-I2I, in het bijzonder p. II4-II6.

583 A.w., p. 44 .

584 NJ 2008, 440 met noot N. Keijzer onder NJ 2008, 442.

585 Zie ook Van de Woude en Van Sliedregt, a.w., p. 224, die van de rechter verwachten dat hij waakt tegen het doorslaan van de balans tussen collectieve veiligheid en individuele rechtsbescherming naar de kant van de collectieve veiligheid.

586 A.w., p. 36. 
varen. Feit blijft immers dat een veroordeling ter zake van een culpoos gevolgsdelict een zwaar persoonlijk verwijt inhoudt. Dat wordt niet anders wanneer in aanmerking wordt genomen dat een slachtoffer zich door een vrijspraak van een verdachte van een culpoos delict miskend kan voelen. Aansprakelijkstelling op grond van het civiele recht en hulp bij het verwerken van de gevolgen van het ongeval zullen hier soelaas moeten bieden.

Een andere vraag is of de behoefte van het slachtoffer of diens nabestaanden en het belang van de samenleving om helderheid te krijgen over de toedracht van een fataal ongeval onder omstandigheden mogen meewegen bij de vervolgingsbeslissing in die zin dat ook indien de onderbouwing van de vereiste mate van schuld niet sterk is toch tot vervolging wordt overgegaan. Het strafprocesrecht biedt immers - zowel qua bevoegdheden als qua deskundigheid in de opsporing - bij uitstek het instrumentarium om de feitelijke toedracht op te helderen. Ik ben geneigd deze vraag met name bij dodelijke ongevallen met een voorzichtig ja te beantwoorden. Laat hier gezien de ernst van de gevolgen niet het Openbaar Ministerie maar de meervoudige kamer van rechtbank of hof na een openbaar onderzoek het laatste woord hebben.

\subsubsection{Culpa ten aanzien van een omstandigheid}

Hetgeen hiervoor is beschreven ten aanzien van culpoze gevolgsdelicten geldt in grote trekken ook voor culpa ten aanzien van een strafbaarheid constituerende omstandigheid. Het is zaak de aan een verdachte te stellen eisen af te stemmen op de maatschappelijke realiteit en niet uit een oogpunt van effectiviteit van de strafrechtspleging - ik denk hier bijvoorbeeld aan de bestrijding van heling en fraude bij sociale verzekeringen - buitensporig hoge eisen aan een verdachte te stellen. In dit verband verdient opmerking dat het gevaar van hindsight bias bepaald niet is beperkt tot culpoze gevolgsdelicten. Ook bij culpa ten aanzien van de omstandigheden is de verleiding groot op grond van de achteraf bekend geworden feiten zwaar te tillen aan enige onoplettendheid of onvoorzichtigheid. Zo zien we dat rechters bij veroordeling voor schuldheling soms opvallend lage eisen stellen aan de schuld ten aanzien van het van misdrijf af komstig zijn van de onder de verdachte aangetroffen, inderdaad van misdrijf afkomstige goederen. ${ }^{587} \mathrm{Ik}$ wijs ook op de in de ogen van de Hoge Raad te lichtvaardige wijze waarop rechters soms tot het oordeel komen dat een bestuurder redelijkerwijs had moeten weten dat de geldigheid van zijn rijbewijs was geschorst of zijn rijbewijs ongeldig was verklaard (art. 9 lid 2 c.q. lid 5 WVW I994)..$^{58}$

587 Bijv. HR 2I april 2009, LJN BH4080, HR 9 februari 2010, LJN BK6943, HR 25 mei 2010, LJN BL5625, HR 29 maart 20II, LJN BP3838, HR I4 juni 20II, LJN BQ 3745.

588 HR 9 maart 20I0, LJN BK6I40, VR 20I0, 95, HR 2I september 20I0, LJN BM94Io, VR 20II, 47, HR 25 januari 20II, LJN BO6762, VR 20II, I09, m.nt. Simmelink, HR I3 maart 20I2, LJN BV6666, NJ 2012, 320, m.nt. T.M. Schalken, HR 20 maart 2012, LJN BV8246, NJ 2012, 321, m.nt. T.M. Schalken, HR 29 mei 20I2, LJN BW6673. 


\subsection{Nog een enkel desideratum}

De oriëntatiepunten straftoemeting (zie 5.7) vullen de aanmerkelijke schuld in aan de hand van betrekkelijk abstracte begrippen als wegpiraterij/roekeloos rijden, grove verkeersfout en aanmerkelijke verkeersfout. Met deze begrippen is nog niet zoveel gezegd. Bovendien valt het op dat deze begrippen niet parallel lopen aan de culpa zoals deze ten laste wordt gelegd. Deze is immers niet toegesneden op verdachtes gedrag maar op zijn schuld in de vorm van onoplettendheid, onachtzaamheid, onvoorzichtigheid of roekeloosheid aan - hier - dood of (zwaar) lichamelijk letsel. In feite zijn de oriëntatiepunten gebaseerd op het gelijkstellen van culpa aan uiterlijk onvoorzichtig gedrag. Zoals we hiervoor hebben gezien strookt die opvatting niet met de huidige stand van de rechtspraak van de Hoge Raad. Het is dus wenselijk dat de in de oriëntatiepunten gehanteerde categorieën worden toegesneden op de schuld zoals deze wordt tenlastegelegd. Voorts is het uit een oogpunt van gelijkheid in straftoemeting van belang dat aan deze begrippen enige inhoud wordt gegeven, al was het (eerst) maar aan de hand van een beschrijving van enige veel voorkomende gevallen. De Engelse sentencing guidelines ${ }^{589}$ kunnen hier tot op zekere hoogte als voorbeeld dienen. Maar het blijft moeilijk: veel te hard door een bocht rijden kan wijzen op roekeloosheid - 'lekker kicken' - maar evenzeer op onvoorzichtigheid - de scherpte van de bocht verkeerd inschatten - of, in geval de bocht te laat is opgemerkt, onoplettendheid. Van de Hoge Raad mag de feitenrechter hier niets verwachten. Daarvoor is deze invulling te veel gebonden aan feitelijke oordelen.

\subsection{Wel schuld doch niet in aanmerkelijke mate, wat dan?}

Ontbreekt het aanmerkelijke van de schuld dan sluit dit niet uit dat de verdachte strafbaar is. In veel gevallen is zijn gedrag immers strafbaar als overtreding. Zo kent het Reglement verkeersregels en verkeerstekens 1990 een keur aan gedragsvoorschriften waarvan het negeren een overtreding oplevert. Dergelijke voorschriften kennen niet de schuld als bestanddeel van de delictsomschrijving. Dit neemt niet weg dat - sinds het Water en melk-arrest (zie 3.2) - het ontbreken van schuld tot straffeloosheid leidt. Dat ontbreken van schuld kan zijn grond vinden in verschoonbare (in termen van Belgisch recht: onoverwinnelijke ${ }^{59^{\circ}}$ ) feitelijke dwaling of - soms - verschoonbare rechtsdwaling, maar ook in het voldoen aan de vereiste normen van zorgvuldigheid. ${ }^{5{ }^{1}}$ Ontbreekt een dergelijk voorschrift, zoals in het in 4.6 besproken geval van het kampvuur te Castricum ${ }^{592}$ en in de zaak van het

589 Zoals de sentencing guideline Causing Death by Driving van juli 2008, te vinden op www.sentencing-guidelines-gov.uk.

590 Chr. Van den Wyngaert, Strafrecht en strafprocesrecht in hoofdlijnen, Antwerpen/Apeldoorn: Maklu 20II, p. 335 .

59I Zie daarover Schuld in spiegelbeeld, diss. Groningen I982, hoofdstuk 5 e.v.

592 HR 29 juni 20I0, LJN BL5630, NJ 2010, 674, m.nt. P.A.M. Mevis. 
klimwandongeval,593 dan leidt het ontbreken van het aanmerkelijke van de schuld tot straffeloosheid ook al valt de verdachte wel enige onoplettendheid of onvoorzichtigheid te verwijten.

\section{Buitenland}

\section{I Inleiding}

De eis van de aanmerkelijkheid van de schuld brengt mee dat dood en zwaar lichamelijk letsel door schuld in Nederland niet strafbaar zijn wanneer die schuld niet 'aanmerkelijk' is. De vraag is of en in hoeverre het Nederlandse recht daarin met buitenlandse rechtsstelsels uit de pas loopt. Voor het Belgische recht is dat, zoals blijkt uit het preadvies van mijn medepreadviseur, zonder meer het geval. Het Belgische recht kent immers de eis van de aanmerkelijkheid der schuld niet. Dat geldt ook voor enkele andere rechtsstelsels, zij het dat er wel wordt gevarieerd op dit thema. Daarnaast rijst de vraag of in buitenlandse rechtsstelsels aan zware vormen van culpa zoals roekeloosheid strafverhoging wordt verbonden. ${ }^{594}$

\subsection{Duitsland}

Fahrlässige Tötung is strafbaar gesteld in $\$ 222$ StGB, fahrlässige Körperverletzung in $\$ 229$ StGB. Anders dan in het Nederlandse strafrecht is de strafbaarheid voor het toebrengen van letsel niet beperkt tot-kort gezegd - in ernst of gevolgen zwaardere vormen van lichamelijk letsel. Pogingen om door middel van hervorming van het strafrecht lichte vormen van culpa van Fahrlässigkeit uit te zonderen en zo te komen tot decriminalisering van dood en lichamelijk letsel door geringe schuld zijn uiteindelijk op niets uitgelopen. Het Duitse strafrecht kent dus geen ondergrens voor de culpa zoals het Nederlandse strafrecht. Dit neemt niet weg dat de vraag of aan de culpa geen ondergrens moet worden verbonden een punt van regelmatig terugkerende discussie lijkt te zijn. ${ }^{595}$

Soms wordt met Fahrlässigkeit geen genoegen genomen en wordt een zwaardere vorm van culpa geëist, Leichtfertigkeit, zoals bijvoorbeeld in $\S 30$ BtMG. ${ }^{596}$ In die

593 HR 7 februari 20I2, LJN BU2878, NJ 20I2, II9; de Hoge Raad verwierp het beroep van het Openbaar Ministerie tegen de vrijspraak.

594 De bevindingen van het op 7 september 2012 in Groningen gehouden congres 'International Conference on Criminal Liability for Serious Traffic Offences' konden niet meer in de tekst worden verwerkt.

595 O.a. A. Koch, Die Entkriminalisierung im Bereich der fahrlässigen Körperverletzung und Tötung, Berlin: Duncker \&Humblot I998, M.S. Greiff, Notwendigkeit und Möglichkeiten einer Entkriminalisierung leicht fahrlässigen ärtzlichen Handelns, Hamburg: Verlag Dr Kovač 2005, F. Pfefferkorn, Grenzen strafbarer Fahrlässigkeit im französischen und deutschen Recht, Berlin: Duncker \& Humblot 2006, Kristian Kühl, Strafrecht Allgemeiner Teil, München: Verlag Franz Vahlen 2008, p. 525.

596 Zo ook $\S \S 306 \mathrm{c}$ (brandstichting met de dood van een ander als gevolg) en 3i6a (overval op een bestuurder van een motorvoertuig met diens dood als gevolg) StGB. Voorts $§$ 26I StGB Abs. 5 (schuldwitwassen). 
bepaling wordt strafbaarheid verbonden aan het verstrekken van verdovende middelen aan iemand en het daardoor 'leichtfertig dessen Tod' veroorzaken. Komt die Leichtfertigkeit niet vast te staan dan sluit dat niet uit dat toch nog van 'einfacher Fahrlässigkeit' sprake is en iemand kan worden vervolgd ter zake van § 222 StGB.597 Pas bij 'grober Fahrlässigkeit' is van Leichtfertigkeit sprake. ${ }^{598}$

Het 'grob verkehrswidrig und rücksichtslos' door gedragingen als geen voorrang verlenen in gevaar brengen van personen of van waardevolle zaken in het verkeer ( $\$ 315 c$ StGB), is bedreigd met een vrijheidsstraf van dezelfde hoogte - vijf jaar - als het culpoos veroorzaken van de dood van een ander ( $\$ 222$ StGB).

\subsection{Oostenrijk}

In de strafbaarheid van dood en lichamelijk letsel door schuld wordt voorzien door $\$ \S 80$ en 88 StGB. Anders dan het Duitse kent het Oostenrijkse strafrecht wel een vorm van decriminalisering van gevallen van lichte schuld. Deze wordt zowel gezocht in de mate van schuld enerzijds als in de verwantschap tussen de verdachte en het slachtoffer en in de ernst van de gevolgen anderzijds:

'§ 88. (I) Wer fahrlässig einen anderen am Körper verletzt oder an der Gesundheit schädigt, ist mit Freiheitsstrafe bis zu drei Monaten oder mit Geldstrafe bis zu I80 Tagessätzen zu bestrafen.

(2) Trifft den Täter kein schweres Verschulden und ist entweder

I. die verletzte Person mit dem Täter in auf- oder absteigender Linie verwandt oder verschwägert oder sein Ehegatte, sein eingetragener Partner, sein Bruder oder seine Schwester oder nach $\S 72$ Abs. 2 wie ein Angehöriger des Täters zu behandeln,

(...)

3. aus der Tat keine Gesundheitsschädigung oder Berufsunfähigkeit einer anderen Person von mehr als vierzehntägiger Dauer erfolgt,

so ist der Täter nach Abs. I nicht zu bestrafen.'

Tegenover straffeloosheid van deze gevallen van lichte schuld staat een strafverzwaring in geval van 'fahrlässige Tötung unter besonders gefährlichen Verhältnissen', zoals gebruik van alcohol door de verdachte in het vooruitzicht dat hij een gedraging zal gaan verrichten die door het gebruik van alcohol gevaar voor anderen zal opleveren of vergroten.

\subsection{Frankrijk}

Aan het Franse strafrecht ligt ten grondslag het 'principe d' identité des fautes civile et pénale'. Dit beginsel vloeit voort uit de regel dat een strafrechtelijke vrijspraak in de weg staat aan een civielrechtelijke veroordeling voor de schade. Dit betekent dat voor culpoze delicten ieder 'faute' voldoende is, in art. I2I-3 CP omschreven als:

597 BGH II december 2003, 3 StR I20/03.

598 Kühl, a.w., p. 525 . 
'Il y a également délit, lorsque la loi le prévoit, en cas de faute d'imprudence, de négligence ou de manquement à une obligation de prudence ou de sécurité prévue par la loi ou le règlement, s'il est établi que l'auteur des faits n'a pas accompli les diligences normales compte tenu, le cas échéant, de la nature de ses missions ou de ses fonctions, de ses compétences ainsi que du pouvoir et des moyens dont il disposait.'

De invulling van de culpa heeft door de nauwe band met het civiele recht een sterk objectieve inslag. ${ }^{599}$ In de Franse rechtspraak wordt van de gelijkstelling van de strafrechtelijke 'faute' met de civielrechtelijke soms afstand genomen. Dat kan omdat de civielrechtelijke aansprakelijkheid in toenemende mate wordt geobjectiveerd en een strafrechtelijke vrijspraak daardoor niet meer aan civielrechtelijke (risico)aansprakelijkheid in de weg staat. Pfefferkorn, aan wie ik het voorgaande ontleen, ${ }^{600}$ wijst erop dat menige rechter voor de veroordeling van artsen wegens een verkeerde diagnose een 'faute lourde' verlangt.

De veroordeling van burgemeesters wegens dood of zwaar lichamelijk letsel door schuld omdat zij de naleving van veiligheidsvoorschriften niet hadden gecontroleerd (bij brand in een discotheek, de instorting van een stadion e.d.) deed de behoefte ontstaan de aansprakelijkheid van bestuurders voor culpoze delicten te begrenzen. ${ }^{601}$ Die begrenzing heeft men gezocht in het stellen van hoge eisen aan de culpa van personen die niet direct de dood of het letsel hebben veroorzaakt (art. I2I-4 CP).

\subsection{Engeland}

Gelet op de van het continentale recht afwijkende structuur van het Engelse recht is het moeilijk een compleet beeld te krijgen van de ondergrens van de culpa in het Engelse recht of een daarmee te vergelijken begrip. In het Engelse recht valt het culpoos veroorzaken van dood, ook in het verkeer, onder homicide - murder of manslaughter - met de daaraan verbonden hoge eisen voor het bewijs. Zo wordt voor 'gross negligence manslaughter' - de 'ondergrens' van manslaughter - in het verkeer geëist 'that the driving falls far below the minimum acceptable standard of driving; and there is an obvious and serious risk of death;(...). ${ }^{602}$ Cunningham schrijft dat 'manslaughter is a charge reserved for the most serious cases and is a rare occurrance in cases involving driving'. ${ }^{603}$ De daardoor als ontoereikend ervaren mogelijkheden van bestraffing van dood in het verkeer leidden tot een nieuw, door het gevolg gekwalificeerd delict, Causing Death bij Careless Driving (CDCD). ${ }^{604}$ Dit delict - thans section 3A Road Traffic Act I988 - werd ingevoerd bij de Road Safety Act 2006 en trad in werking in augustus 2008 . Het voorzag in een hogere straf voor careless driving, wanneer dit tot de dood had geleid. Een geval van momen-

\footnotetext{
599 Pfefferkorn, a.w., p. 45 e.v.

600 A.w., p. 3I-42.

6or Pfefferkorn, p. ro5 e.v.

602 Road Traffic Offences Guidance on Prosecuting Cases of Bad Driving (te vinden op www.cps. gov.uk/legal), onder 'gross negligence manslaughter'.

603 Sally Cunningham, Driving Offences Law, Policy and Practice, Ashgate 2008, p. 96.

604 Zie over de geschiedenis van de totstandkoming Cunningham, a.w.
} 
tane onoplettendheid wordt daaronder kennelijk begrepen: de sentencing guideline Causing Death by Driving verstaat onder careless driving als lichtste vorm "careless or inconsiderate driving arising from momentary inattention with no aggravating factors'. ${ }^{605}$ Wel laten de sentences guidelines $z^{2}{ }^{60}{ }^{606}$ dat die vorm als licht wordt ervaren doordat als 'starting point' wordt genomen de 'community order', terwijl voor zwaardere vormen de vrijheidsstraf uitgangspunt vormt.

\subsection{De Verenigde Staten}

Het Amerikaanse recht lijkt in beginsel meer te neigen naar een ondergrens van de culpa zoals we die ook in het Nederlandse recht kennen: 'culpable negligence in the law of crimes necessarily implies something more than actionable negligence in the law of torts'. In State v. Phelps,${ }^{607}$ waaraan dit citaat is ontleend, stond dit uitgangspunt er niet aan in de weg dat Phelps schuldig werd bevonden aan de dood van de overstekende, door hem aangereden voetganger Monds omdat hij niet geheel op de voor hem rechter weghelft reed en bovendien niet kon zeggen of Monds voor hem van links of van rechts de weg overstak zodat hij kennelijk niet goed had opgelet op het verkeer dat zich voor hem bevond. Voor 'criminal negligence' is dus 'gross negligence' vereist. ${ }^{608}$ Daarnaast kennen veel staten - in afwijking van de Model Penal Code die steeds 'gross negligence' eist - de zgn. 'misdemeanor-manslaughter rule'. Deze maakt het mogelijk iemand te veroordelen wegens 'involuntary manslaughter' als de dood is veroorzaakt door het negeren van verkeersregels. ${ }^{609}$

\subsection{Conclusie}

Zoveel landen, zoveel zienswijzen dus. Eén ding is duidelijk: de ondergrens van de culpa vormt overal een punt van discussie. Onderlinge vergelijking lijkt niet wel mogelijk omdat het al dan niet hanteren van een ondergrens voor de strafbaarheid van culpa niet los kan worden gezien van strafbaarheid voor een ander delict dan een culpoos (gevolgs)delict. Daardoor valt ook de vraag of in buitenlandse rechtsstelsels aan zware vormen van culpa zoals roekeloosheid strafverhoging wordt verbonden niet goed te beantwoorden. Zo zien we in Engeland en de Verenigde Staten 'recklessness' juist fungeren als ondergrens voor manslaughter terwijl in het Duitse recht aan het 'grob verkehrswidrig und rücksichtslos' handelen in het verkeer zo zwaar wordt getild dat dit wordt bedreigd met dezelfde straf als het culpoos veroorzaken van iemands dood, ook al blijft het slechts bij gevaar voor andere personen of waardevolle zaken.

605 Causing Death by Driving, Definitive Guideline july 2008, p. I5.

606 P. I5.

607 Supreme Court of North Carolina, 2I september 1955; verwijzing ontleend aan Koch, a.w., p. 227.

608 Steven L. Emanual, Criminal law, New York: Aspen Publishers 2007, p. II, 32, I38.

609 Emanuel, a.w. p. I39, I40. 


\section{Culpa en 'positive obligations'}

De begrenzing van de culpa tot aanmerkelijke schuld brengt mee dat gevallen waarin dood of zwaar lichamelijk letsel aan schuld, lichter dan aanmerkelijke schuld, is te wijten niet tot strafrechtelijke veroordeling ter zake van het veroorzaken van die gevolgen kan leiden. Dat roept de vraag op of de straffeloosheid van minder dan aanmerkelijke schuld verenigbaar is met de procedurele en materieelrechtelijke verplichtingen die voor de staat voortvloeien uit de art. 2 en 3 EVRM, (positieve) verplichtingen tot deugdelijk onderzoek, tot vervolging en tot effectieve straf(bedreiging) ${ }^{6}{ }^{\text {ro }}$ In gevallen, waarin op voorhand wel van een verdenking van schuld maar niet van aanmerkelijke schuld sprake is, zal immers niet steeds een uitgebreid strafvorderlijk onderzoek plaatsvinden naar de toedracht van het gebeuren. Er zijn twee punten die hier de aandacht verdienen. De art. 2 en 3 EVRM brengen in geval van culpoos toebrengen van dood of - kort gezegd - zwaar lichamelijk letsel niet steeds mee dat inschakeling van het strafrecht de enige wijze is waarop de staat kan voorzien in de op haar op grond van art. 2 en 3 EVRM rustende verplichtingen. Onder omstandigheden kan worden volstaan met een andere wijze van voorzien in de bescherming van het leven, zoals door het bieden van de mogelijkheid van een deugdelijke civiele procedure. ${ }^{6 \text { II }}$ Anderzijds zijn er gevallen waarin juist bij uitstek het strafrecht dient te worden ingeschakeld omdat alleen de daardoor geboden middelen van onderzoek, vervolging en bestraffing in een effectieve bescherming van de in art. 2 en 3 EVRM vervatte grondrechten kunnen voorzien. ${ }^{612}$

Uit het beperken van de strafrechtelijke aansprakelijkheid voor dood en zwaar lichamelijk letsel door schuld tot gevallen van aanmerkelijke schuld vloeit niet zonder meer voort dat niet aan de uit art. 2 en 3 EVRM voortvloeiende positieve verplichtingen wordt voldaan. Doorgaans leiden gevallen van dood en zwaar lichamelijk letsel dat door een ander veroorzaakt lijkt te zijn tot strafvorderlijk onderzoek ${ }^{613}$ omdat uit die gang van zaken in de regel op het eerste gezicht een redelijk vermoeden aan dood of zwaar lichamelijk letsel door schuld voortvloeit of in elk geval veelal een

6Io Zie EHRM 28 oktober I998, Osman v. The United Kingdom, NJ 2000, I34 m.nt. EAA, NJCM-bull. I999, p. 5 I2 e.v., m.nt. E. Myjer, par. II5. Kortheidshalve verwijs ik hier verder naar F.VellingaSchootstra en W.H. Vellinga, 'Positive obligations' en het Nederlandse straf(proces)recht, oratie, Kluwer 2008, p. 9-I4. Zie voorts over positieve verplichtingen in het algemeen A.R. Mowbray, The Development of Positive Obligations under the European Convention on Human Rights by the European Court of Human Rights, Hart Publishing 2004, Jean-François Akandji-Kombe, Positive obligations under the European Convention on Human Rights, Directorate General of Human Rights, Council of Europe, Straatsburg 2007, P.H.P.H.M.C. van Kempen, Re-pressie door mensenrechten, oratie, Nijmegen: Wolf Legal Publishers 2008, en Dimitris Xenos, The positive obligations under the European Convention of Human Rights, Taylor \& Francis 20II, alsmede de in de genoemde publicaties aangehaalde literatuur.

6II EHRM I7 januari 2002, Cavello and Ciglio v. Italy, EHRC 2002, 22, m.nt. J. van der Velde, par. 5I, EHRM 20 maart 2008, Budayeva and others v. Russia, EHRC 2008, 73, m.nt. H.L. Janssen, par. I39, EHRM 9 april 2009 (Grand Chamber), Šilih v. Slovenia, appl. no. 71463/oI, par. I94.

6I2 EHRM 2 december 2008, K.U. v. Finland, appl. no. 2872/02, par. 43, t.a.v. art. 8 EVRM.

6I3 Vgl. Aanwijzing verkeersongevallen I4 december 2009, Stcrt. 2009, nr. I9483, onder 3.3.2: Wanneer het verkeersongeval de dood, zwaar lichamelijk letsel of zodanig lichamelijk letsel dat daaruit tijdelijke ziekte of verhindering in de uitoefening van de normale bezigheden ontstaat, tot gevolg heeft, wordt proces-verbaal ter zake artikel 6 WVW 1994 opgemaakt. 
redelijk vermoeden van schending van strafrechtelijk gesanctioneerde veiligheidsvoorschriften. Leidt dit onderzoek niet tot een strafrechtelijk vervolg, dan kunnen de resultaten van het onderzoek in daartoe, gelet op het verzamelde bewijs, in aanmerking komende gevallen dienen als grondslag voor een civiele vordering uit onrechtmatige daad of worden meegenomen in een eventuele tuchtrechtelijke procedure.

\section{Rechtvaardiging van de bestraffing van culpoze delicten}

De rechtvaardiging van de bestraffing van culpoze delicten levert in de theorie $\mathrm{e}^{6 \mathrm{r} 4}$ met name problemen op voor gevallen van onbewuste schuld. Kern van het probleem is dat in geval van onbewuste schuld een subjectief verwijt moeilijk lijkt te vinden omdat een goede persoonlijke instelling onbewuste schuld niet steeds kan voorkomen. ${ }^{615}$ Robroek $^{616}$ ziet hierin aanleiding ervan af te stappen een subjectief verwijt te zoeken ter rechtvaardiging van de bestraffing van onbewuste schuld. Hij zoekt de rechtvaardiging van de bestraffing van culpoze delicten, ook in geval van onbewuste schuld, in objectieve maatschappelijke schuld, voortvloeiend uit het plegen van enige normovertreding, en sterk gerelateerd aan de functie die de onbewust culpoze dader meestal bekleedt. ${ }^{67}$ Robroek gaat er - door zich te oriënteren op het soms negeren van het vereiste van de aanmerkelijke schuld door feitenrechters - echter aan voorbij dat de vraag naar de rechtvaardiging van de bestraffing van culpoze delicten niet een vraag is naar de rechtvaardiging van de bestraffing van gevallen van schuld maar van aanmerkelijke schuld.

Zoals onder 5.5 naar voren is gekomen bestaat de kern van het aanmerkelijke van de schuld in gebrek aan voorzorg. Pas wanneer de (on)bewuste schuld gepaard is gegaan met gebrek aan voorzorg wordt de drempel van aanmerkelijkheid overschreden. Dat brengt mij op het onderzoek van Van Dijk naar de grondslag van de strafrechtelijke aansprakelijkheid. ${ }^{618}$ Van Dijk, die aan de ondergrens van de aanmerkelijke schuld overigens ten onrechte geen waarde toekent, ${ }^{619}$ zoekt de grondslag van de aansprakelijkheid voor culpoze delicten in het hebben van controle over het al dan niet schenden van de in de maatschappij geldende norm. ${ }^{620}$ Culpoze aansprakelijkheid, aldus Van Dijk, ${ }^{62}$ is niet gebaseerd op een keuze voor het strafbare feit maar op het niet kiezen voor het vermijden van dit feit. ${ }^{622}$ De belangrijkste grondslag van niet doleuze schuld ziet Van Dijk in latente kennis. 'Deze latente kennis kan

6I4 Voor een overzicht van theorieën verwijs ik naar Robroek, a.w., hoofdstuk 6, en Van Dijk, a.w., p. 56 .

6I5 Robroek, a.w., p. I63.

6 I6 A.w., p. I27.

617 A.w., p. I69.

6I8 A.A. van Dijk, Strafrechtelijke aansprakelijkheid heroverwogen. Over opzet, schuld, schulduitsluitingsgronden en straf, diss. Groningen 2008.

6I9 A.w., p. 7I, I90.

620 A.w., p. I9I.

621 A.w., p. 62.

622 In deze zin ook Roef, a.w., p. 46. 
onder omstandigheden het oordeel rechtvaardigen dat de actor de overtreding en het daardoor veroorzaakte gevolg had kunnen voorkomen. ${ }^{623}$

Zo gezien behoeft de rechtvaardiging van de bestraffing van gevallen van aanmerkelijke schuld geen wezenlijke problemen op te leveren. Het voor aanmerkelijke schuld doorgaans vereiste gebrek aan (normale) voorzorg betekent immers dat men in de kern van de zaak niet heeft gekozen voor het vermijden van het feit.

\section{$9 \quad$ Moeten wij gelukkig zijn met het vereiste van de mate van schuld?}

Het voorgaande laat zien dat de eis van aanmerkelijke schuld nogal wat problemen oproept. Bij de invulling weegt een veelheid van deels uiteenlopende factoren mee: er dient acht te worden geslagen op hetgeen uit andere wetenschappen bekend is over de capaciteiten van mensen, slachtoffers of hun nabestaanden hebben soms niet te vervullen verwachtingen van het strafrecht, er kan niet worden geabstraheerd van de vraag hoe we de samenleving willen inrichten, en zo meer. In concreto laten zich soms scherpe verschillen in opvatting over de inhoud van de aanmerkelijke schuld zien die leiden tot uiteenlopende uitkomsten, ${ }^{624}$ zowel in al dan niet veroordelen als in de hoogte van de straf. Er valt dus nog wel het een en ander te verbeteren, in het bijzonder in het bieden van handvatten voor de invulling van de aanmerkelijke schuld en het betrekken van de kennis van andere wetenschappen daarbij.

Toch betekent dit niet dat we het vereiste van de aanmerkelijke schuld moeten laten varen. Integendeel, het vormt de erkenning van de zwaarte van het persoonlijk verwijt dat iemand wordt gemaakt, in het bijzonder bij de culpoze gevolgsdelicten. 'When it comes to compensating an injured person for damages suffered, the one who has negligently injured an innocent victim ought to pay for it; but when the problem is one of whether to impose criminal punishment on the one who caused the injury, then something extra - beyond ordinary negligence - should be required. ${ }^{625}$

Uit een oogpunt van evenwichtige toepassing van het strafrecht kan worden gezegd dat het strafrecht thans een te grote discrepantie creëert tussen de toevallig ongelukkige en de gelukkige roekeloze. De wet legt door de zware maximumstraffen op culpoze gevolgsdelicten wel erg zwaar de nadruk op het veroorzaken van het gevolg in plaats van op het tekortschieten van de persoon. We plegen de normale risico's van het maatschappelijk verkeer, verbonden aan menselijke en technische onvolmaaktheid, te aanvaarden, niet die verbonden aan het te lichtvaardig omspringen met andermans lijf en leven. Dat laatste, het nemen van maatschappelijk gezien onaanvaardbare risico's, dient af te stuiten op het strafrecht, ongeacht de daaraan verbonden gevolgen. Een abstract gevaarzettingsdelict in de geest van par. 3I5C

623 A.w., p. 6r.

624 Zie bijvoorbeeld het verschil tussen $\mathrm{HR} 7$ januari 2006, LJN AU3447, NJ 2006, 303, m.nt. Buruma (taxibusje) en de daarbij behorende conclusie.

625 Wayne R. LaFave, Criminal law, West 2003, vierde druk, p. 262. 
$\mathrm{StGB}^{626}$ met de daarbij behorende handhavingsinspanning kan daarin voorzien. Invoering van een dergelijke bepaling vindt steun in de wetenschap dat er sterke aanwijzingen zijn dat wie vaker ernstige verkeersovertredingen pleegt ook vaker bij ongevallen betrokken pleegt te zijn. ${ }^{627}$

Uiteindelijk is de invulling van het vereiste van de mate van schuld een vraag van hoe we de samenleving inrichten, dus hoe we met elkaar om dienen te gaan. Misschien is daarom het antwoord op de vraag naar het aanmerkelijke van de schuld wel zo moeilijk.

626 Par. 3I5c StGB luidt:

(I) Wer im Straßenverkehr

I. ein Fahrzeug führt, obwohl er

a) infolge des Genusses alkoholischer Getränke oder anderer berauschender Mittel oder

b) infolge geistiger oder körperlicher Mängel

nicht in der Lage ist, das Fahrzeug sicher zu führen, oder

2. grob verkehrswidrig und rücksichtslos

a) die Vorfahrt nicht beachtet,

b) falsch überholt oder sonst bei Überholvorgängen falsch fährt,

c) an Fußgängerüberwegen falsch fährt,

d) an unübersichtlichen Stellen, an Straßenkreuzungen, Straßeneinmündungen oder Bahnübergängen zu schnell fährt,

e) an unübersichtlichen Stellen nicht die rechte Seite der Fahrbahn einhält,

f) auf Autobahnen oder Kraftfahrstraßen wendet, rückwärts oder entgegen der Fahrtrichtung fährt oder dies versucht oder

g) haltende oder liegengebliebene Fahrzeuge nicht auf ausreichende Entfernung kenntlich macht, obwohl das zur Sicherung des Verkehrs erforderlich ist,

und dadurch Leib oder Leben eines anderen Menschen oder fremde Sachen von bedeutendem Wert gefährdet, wird mit Freiheitsstrafe bis zu fünf Jahren oder mit Geldstrafe bestraft.

(2) In den Fällen des Absatzes I Nr. I ist der Versuch strafbar.

(3) Wer in den Fällen des Absatzes I

I. die Gefahr fahrlässig verursacht oder

2. fahrlässig handelt und die Gefahr fahrlässig verursacht, wird mit Freiheitsstrafe bis zu zwei Jahren oder mit Geldstrafe bestraft.

627 Ch. Goldenbeld \& D.A.M. Twisk, Verkeersovertredingen, veelplegers en verkeersonveiligheid, Leidschendam: Stichting Wetenschappelijk Onderzoek Verkeersveiligheid SWOV 2009. 